Canadian Science Publishing

Canadian Journal of Earth Sciences Revue canadienne des sciences de la Terre

\title{
Structure and kinematic evolution of the Duke River fault, Southwestern Yukon
}

\begin{tabular}{|r|l|}
\hline Journal: & Canadian Journal of Earth Sciences \\
\hline Manuscript ID & cjes-2016-0074.R1 \\
\hline Manuscript Type: & Article \\
\hline Complete List of Authors: & $\begin{array}{l}\text { Cobbett, Rose; Yukon Teritorial Government, Energy, Mines and Resources } \\
\text { Israel, Steve; Yukon Geological Survey, } \\
\text { Mortensen, James; Dept Earth and Ocean Sciences } \\
\text { Joyce, Nancy; Natural Resources Canada Earth Sciences } \\
\text { Crowley, James; Department of Geosciences }\end{array}$ \\
\hline Keyword: & $\begin{array}{l}\text { Duke River fault, Insular terranes, southwest Yukon, Cretaceous, } \\
\text { transpression }\end{array}$ \\
\hline &
\end{tabular}

SCHOLARONE $^{\text {Ix }}$

Manuscripts 


\title{
Structure and kinematic evolution of the Duke River fault, Southwestern Yukon
}

\author{
Rosie Cobbett \\ Yukon Geological Survey \\ 91807 Alaska Hwy, Whitehorse, Yukon, Y1A 6C4, Canada \\ Rosie.Cobbett@gov.yk.ca
}

(ph) 867-455-2802

(fax) 867-455-2807

Steve Israel

Yukon Geological Survey

91807 Alaska Hwy, Whitehorse, Yukon, Y1A 6C4, Canada

Steve.Israel@gov.yk.ca

Jim Mortensen

University of British Columbia, Department of Earth and Ocean Sciences

6339 Stores Road, Vancouver, British Columbia, V6T 1Z4, Canada

imortensen@eos.ubc.ca

Nancy Joyce

Geological Survey of Canada

601 Booth Street, Ottawa, Ontario, K1A 0E8, Canada

nancy.joyce@canada.ca

James Crowley

Boise State University, Department of Geosciences

1910 University Drive, Boise, Idaho, 83725-1535, USA

¡imcrowley@boisestate.edu 
Abstract: In southwest Yukon, the boundary between the Alexander terrane and Wrangellia corresponds with the Duke River Fault. In this paper, we report on observations of the Duke River Fault from four localities in southwest Yukon, and provide new constraints on (1) Permian regional metamorphism within the Alexander terrane, (2) Cretaceous ductile deformation along the Duke River fault and (3) post-Miocene brittle deformation along the fault. Within these areas, the Duke River Fault juxtaposes imbricated, pervasively foliated and folded greenschist-facies rocks of the Alexander terrane southwest of the fault against sub-greenschist-facies, less deformed rocks of Wrangellia. Multiple lines of evidence from this region indicate the Alexander terrane has been juxtaposed against Wrangellia along a southwest-dipping thrust fault. ${ }^{40} \mathrm{Ar} /{ }^{39} \mathrm{Ar}$ dates from muscovite, that grew during faulting or have been reset by motion along the Duke River Fault, range from 79 to $105 \mathrm{Ma}$, suggesting that ductile movement along the fault is at least as old as Cretaceous (Albian to Cenomanian). This phase of faulting is interpreted as the local expression of Cretaceous shortening which has been documented the length and width of the Cordillera. Cretaceous structures along the Duke River Fault are overprinted by brittle deformation that affects rocks as young as Miocene (or Pliocene?). The Duke River Fault appears to be accommodating present day transpression through uplift and reactivation of the thrust fault.

Key words: Duke River Fault, Insular terranes, southwest Yukon, Cretaceous, transpression

\section{INTRODUCTION}

The northern Cordillera of western Canada and Alaska is composed of a number of terranes that were accreted to the North American continental margin primarily during the Mesozoic and subsequently disrupted by Mesozoic and younger strike-slip faults (Fig. 1; Monger and Price 1979; Coney et al. 1980; Gabrielse and Yorath 1991; Gabrielse et al. 2006; Nelson et al. 2013). The Alexander terrane and Wrangellia, together with the Peninsular terrane, make up the Insular composite terrane (Colpron et al. 2007). Although some debate on the exact timing of accretion remains, it is accepted by most that 
the Insular terranes accreted to the terranes to the east and the ancient continental margin by Middle Jurassic time (McClelland and Gehrels 1990; Gehrels 2001; van der Heyden 1992; Plafker and Winkler 1994; Manuszak et al. 2007; Israel et al. 2014). The geologic ties between the component terranes of the Insular terranes are not fully understood, however studies focusing on these terranes in Yukon, British Columbia and Alaska have furthered our understanding of their evolution. For example, Gardner et al. (1988) mapped a Pennsylvanian pluton that stitches the basements of Wrangellia and the Alexander terrane, suggesting that the two evolved together since at least that time, and Israel et al. (2014) documented Late Devonian gabbros that intrude both terranes represent initiation of extension in a back arc to the Pennsylvanian-Permian Skolai/Sicker arc which was in part built on the Alexander terrane beginning in the Late Devonian.

In southwest Yukon, the contact between the Alexander terrane and Wrangellia is defined by the Duke River Fault (Fig. 1), which is one of several large faults that dissect the Canadian and Alaskan Cordillera. Other nearby regional-scale faults are the Denali and Totschunda faults (Fig. 1). The Denali fault system is one of the most prominent structural features in southwest Yukon, and is interpreted to have accommodated approximately 300-400 kilometres of right-lateral displacement during the Cenozoic (Eisbacher 1976; Lowey 1998; Murphy et al. 2009). The fault strikes northwest in Yukon and juxtaposes Wrangellia against Yukon-Tanana terrane and various Mesozoic overlap assemblages and plutonic rocks (Fig. 1). The Totschunda fault is a $200 \mathrm{~km}$-long, Late Cenozoic, dextral strike-slip fault that splays south-southeastwardly off the Denali fault in eastern Alaska and may link up with the Duke River Fault near the Yukon-Alaska border (Fig. 1; Plafker 1977; Dodds and Campbell 1992). The currently active segment of the Totschunda fault may connect directly with the northwestern end of the Fairweather fault (the strike-slip portion of the Pacific-North American plate boundary) via an undocumented structure, defined mainly by present seismicity (Fig. 1; Kalbas et al. 2008). 
Muller (1967) mapped the Duke River Fault in Yukon as a moderately to steeply southwestdipping thrust fault along which the Alexander terrane was emplaced over Wrangellia. Mackevett and Jones (1975) interpreted rocks now mapped as the Alexander terrane as being emplaced over those called Wrangellia along a regionally significant thrust fault that accommodated the emplacement of the Taku-Skolai terrane (Wrangellia) over the Alexander terrane in a southwesterly direction. Read and Monger (1976) suggested that the Duke River Fault was a splay off the Denali fault and accommodated some dextral strike-slip movement. More recently, Power (1988) analyzed microseismicity along the Duke River Fault and inferred that shortening was being accommodated by high-angle reverse and thrust faulting. Kalbas et al. (2008), using best-fit models of slip rate estimates along faults in Alaska and southwest Yukon, inferred $1 \mathrm{~mm} /$ a of modern contractional deformation across the northwestern portion of the Duke River Fault.

In this paper we describe the structural and lithologic character of the Duke River Fault and adjacent rocks at four locations in southwest Yukon. Petrographic data from deformed samples from within the fault zone and accompanying geochronological data indicates there were two main phases of displacement across the fault, one in the Albian to Cenomanian and the other probably post-Miocene. We discuss the regional implications of these data and relate Cretaceous fault movement to the final accretion of the Insular terranes to North America and link post-Miocene movement to the subduction of the Yakutat microplate beneath the North American plate.

\section{GEOLOGIC FRAMEWORK}

\section{Stratified Rocks in Alexander terrane}

The Alexander terrane is exposed in eastern and southeastern Alaska, southwestern Yukon and parts of northwestern British Columbia (Fig. 1). In Yukon, the Alexander terrane comprises siliciclastic, carbonate and volcanic rocks ranging in age from Cambrian to Upper Triassic (Fig. 2; Read and Monger 
1976; Dodds and Campbell 1992; Beranek et al. 2012). Rock units, ages and detailed lithologic descriptions of the Alexander terrane rocks exposed near the Duke River Fault are provided in the map legend (Fig. 3).

\section{Stratified Rocks in Wrangellia}

Wrangellia is the larger of the two Insular terranes covering an area extending from southern Alaska to south-westernmost British Columbia (Fig. 1). It is characterized by Late Paleozoic rocks of island arc affinity that are overlain by Mesozoic flood basalts and sedimentary rocks (Fig. 1 and 2).

The oldest succession of layered rocks in Wrangellia in southwest Yukon is the Skolai Group. The Skolai Group consists of Mississippian to Pennsylvanian volcanic and volcaniclastic rocks of the Station Creek Formation gradationally overlain by Permian sedimentary rocks of the Hasen Creek Formation (Smith and MacKevett 1970; Read and Monger 1976; Israel et al. 2007; Israel and Cobbett 2008). The Skolai Group is unconformably overlain by Upper Triassic volcanic and marine sedimentary rocks. Rock units, ages and detailed lithologic descriptions of this terrane are provided in the map legend (Fig. 3).

\section{Links between Alexander terrane and Wrangellia}

Intrusive rocks with a wide range of ages and compositions crop out throughout southwest Yukon and occur in both the Alexander terrane and Wrangellia. The oldest of these found in Yukon are Late Devonian (364 Ma) gabbros that intrude the Goatherd and Bullion assemblages of Alexander terrane and sit unconformably below the Early Permian Hasen Creek Formation of Wrangellia (Fig. 2; Sharp 1943; Dodds and Campbell 1992; Israel et al. 2014). The Pennsylvanian to Permian Icefield Ranges Suite (306-285 Ma) consists of biotite-hornblende syenite, quartz monzodiorite and diorite (Dodds and Campbell 1992) and intrudes both Wrangellia and the Alexander terranes (Gardner et al. 1988; Beranek 
et al. 2014). Locally, near the Duke River and Denali faults, mafic and ultramafic bodies of the Early Cretaceous Pyroxenite Creek Suite intrude strata of Alexander and Wrangellia terranes (Gordey and Makepeace, 2001; Cobbett 2013a). Small volumes of intermediate to felsic intrusions of the Oligocene Tkope Suite and the Miocene to Pliocene Wrangell Suite are found both in the Alexander terrane and Wrangellia (Dodds and Campbell 1992).

Several stratigraphic sequences overlie both the Alexander terrane and Wrangellia (Fig. 2). The oldest of these are Upper Jurassic to Lower Cretaceous sandstone, shale, conglomerate, limestone and volcaniclastic rocks of the Dezadeash Formation, which interpreted to unconformably overlap rocks of Wrangellia in Southwest Yukon. The Dezadesh Formation has been correlated with the Gravina belt in Southeast Alaska where similar aged marine clastic strata and mafic to intermediate rocks sit unconformably on Alexander terrane strata (Fig. 2). It has been hypothesized that these rocks were deposited in a basin (or basins) that developed between the Insular and Intermontane composite terranes (Smith and MacKevett 1970; Eisbacher 1976; Read and Monger 1976; Gehrels and Berg, 1992; Lowey 1992; McClelland et al. 1992; Kapp and Gehrels, 1998). Terrestrial clastic sedimentary rocks of the Oligocene Amphitheatre Formation occur near the Denali and Duke River Faults and have been interpreted as syntectonic basins developed along both fault systems (Read and Monger 1976; Ridgway et al. 1992, 2002). Miocene to Pliocene (and younger?) mafic to intermediate volcanic flows, breccias and tuffs of the Wrangell Volcanics outcrop extensively on both terranes, very near the trace of the Duke River Fault and in some places partly bury this structure (Richter et al., 1990).

\section{Structure and Metamorphism}

The structural evolution of Wrangellia is better constrained than that of the Alexander terrane in Yukon mainly because it is more accessible and better exposed. The structural history of the Alexander terrane rocks in Yukon is poorly understood and has traditionally been studied separately 
from Wrangellia because historically, workers thought these two terranes evolved separately until the Jurassic (Israel et al. 2014). In general, northwest-southeast trending folds and faults make up the dominant structural trend in both terranes in southwest Yukon (Dodds and Campbell 1992).

Two generations of regional-scale folds deform lower Paleozoic rocks in the Alexander terrane and are inferred to be Pennsylvanian or older as they are cross-cut by the Icefield Ranges Suite (306-285 Ma) (Read and Monger 1976; Gardner et al. 1988; Dodds and Campbell 1992). The early folds are closed to isoclinal and are overprinted by more open to closed, late folds. Several phases of faulting, including thrust faults of uncertain age, steeply dipping strike-slip faults that are inferred to be related to the Denali fault, and normal faults that have been interpreted to be post-Oligocene (Dodds and Campbell 1992) are found throughout southwest Yukon.

Several phases of deformation, which began in pre-Middle Triassic and continued until the present day, deformed Wrangellian rocks (Read and Monger 1976; Power 1988; Israel and Cobbett 2008). A pre-Middle Triassic contractional event has been inferred on the basis of (1) folded Paleozoic strata overlain by Triassic strata that are less deformed than the older rocks, and (2) an unconformable contact between Triassic and Paleozoic stratigraphic units (Read and Monger 1976; Israel et al. 2007; Israel and Cobbett 2008). A second, post-Triassic, pre-Late Cretaceous contractional event is recorded by regionally extensive, northeast-verging folds and related thrust faults (Read and Monger 1976; Israel and van Zeyl 2005; Israel et al. 2007). Finally, rock units of Wrangellia are deformed by latest Cretaceous to Cenozoic strike-slip and associated second-order faults.

Wrangellia has undergone sub-greenschist- facies metamorphism indicated by prehnite and pumpellyite-bearing volcanic rocks (Read and Wheeler 1976). The Alexander terrane rocks have been metamorphosed to greenschist facies as indicated by the presence of chlorite and actinolite schists and strongly chloritized and epidotized basalt (Read and Monger 1976; Dodds and Campbell, 1992). 


\section{GEOLOGICAL OBSERVATIONS ACROSS THE DUKE RIVER FAULT ZONE}

Detailed 1:10 000-scale mapping was carried out in four areas across the Duke River Fault in southwest Yukon but only three of these are discussed in detail (Fig. 3, 4, 5, 6; Cobbett 2013a, b, c, d). For each area, the geological description is divided into two sections; the footwall and hanging wall. The hanging wall has been imbricated creating a zone of deformation adjacent to the Duke River Fault that is bounded by brittle shear zones (termed 'the imbricate zone' below). The footwall in all areas comprises rocks that belong to Wrangellia as well as overlap assemblages, whereas the hanging wall includes a variety of rocks that belong mostly to the Alexander terrane. In most areas the Duke River Fault is defined as the leading edge of the imbricate zone and marks the boundary between the Alexander terrane and Wrangellia (and rocks that overlap Wrangellia). Figure 3 includes a legend that describes rock units and symbology for all the mapped areas presented in figures 3, 4, 5, and 6.

\section{Dollis Creek Area}

The Duke River Fault in the Dollis Creek area is exposed along an approximately six kilometre-

long, steep-sided, northwest-trending canyon located near the Yukon-British Columbia border (Fig. 1, 3). In this area, the Duke River Fault is a low angle, south-southwest dipping thrust fault that places older, and higher metamorphic grade rocks of the Alexander terrane over younger, lower grade rocks that have been interpreted as overlap assemblages to Wrangellia (Fig. 3). The imbricate zone is approximately 100-300 metres thick and the Duke River Fault is a brittle shear zone. Deformation within the imbricate zone affects Icefield Assemblage rocks and the Pyroxenite Creek diorite with only minor deformation affecting the overlying Wrangell Volcanics. Deformation is characterized by both brittle and ductile fabrics (Fig. 3).

\section{Wrangellia Footwall}


Footwall rocks in the Dollis Creek area include intermediate to mafic intrusions of the Pyroxenite Creek Suite and volcanic rocks of the Miocene Wrangell Volcanics. Rocks lying directly along the fault in the central part of the map include altered diorite. In the northwest and southeast parts of the map rocks along the fault comprise basalt and crystal tuff. The diorite is green, medium-grained and actinolite-bearing, containing minor amounts of epidote and abundant chlorite. This body of diorite is inferred to intrude the Station Creek Formation, although the contact was not observed (Fig. 3). The Wrangell Volcanics are characterized by dark grey, fine-grained, amygdaloidal and magnetite-bearing basalt and beige rhyolitic tuffs with quartz crystals up to $3 \mathrm{~mm}$ in an aphanitic matrix. Both the basalt and the crystal tuff unconformably overlie Station Creek rocks and Pyroxenite Creek diorite. Near the Duke River Fault, this tuff contains post-lithification fabrics that include two closely-spaced fracture sets that dip steeply to the northeast and moderately to the east.

Away from the fault to the east, the Station Creek Formation includes augite-phyric basalt breccia, agglomerate and volcaniclastic sandstone overlain by light grey and light green, very finegrained tuffs interbedded with volcaniclastic siltstone.

The Station Creek Formation rocks are deformed by open folds that plunge very shallowly to the northwest and have been interpreted as the product of a regional folding event that affects Wrangellia (Israel et al. 2008). These folds are intruded by latest Triassic granodiorite and both pre-date Duke River Fault deformation.

\section{Alexander terrane hanging wall}

Within the hanging wall of the Duke River Fault near Dollis Creek, the lowest thrust panel comprises imbricated, strongly sheared and fractured rocks of Alexander terrane overlain by less deformed rocks of the terrane. Rocks lying directly along the fault within this thrust panel are thin bedded, calcareous and carbonaceous siltstone and phyllite with rare muscovite-rich quartzite that 
belong to the Icefield assemblage (DTrI2; Fig. 3). Overlying this unit in the northern part of the area is thin bedded limestone (DTrl4) and carbonaceous muscovite \pm feldspar \pm quartz schist (DTrl1). In the central and southern parts of the map sheet the bedded limestone is absent. In the structurally highest thrust panel, beige-orange altered marble of the Bullion assemblage forms steep, blocky outcrops. This unit, where it crops out several hundred metres away from the Duke River Fault, is a grey weathered, laminated to thinly foliated silty limestone. In the southwest corner of the map area, calcareous and carbonaceous siltstone, chlorite schist and banded limestone of undifferentiated Icefield assemblage (DTrl4b) cores a northwest-trending antiform (Fig. 3). The Bullion assemblage carbonate is intruded by a green, medium-grained hornblende gabbro body of unknown age (Fig. 3).

Regional foliation and bedding within the Alexander terrane rocks (outside the imbricate zone) strike northwest and dip to the southwest and northeast. Regional northwest-trending folds occur west of the Duke River Fault and are consistent with regional-scale structures mapped by Dodds and Campbell (1992). Outcrop-scale folding was not observed in the Alexander terrane rocks outside the imbricate zone of the Duke River Fault. The gabbro body that crops out in the southwest part of the map ranges from undeformed to deformed by closely spaced brittle fractures with random orientations.

The Duke River Fault penetratively deforms a diorite body in the footwall of the fault. The penetrative foliation strikes southeast and dips steeply to the southwest and becomes less intense away from the fault. The weakly-developed foliation is defined by flat aggregates of actinolite needles (commonly radial), elongate chlorite grains and dynamically recrystallized quartz grains that anastomose between larger blocky amphibole grains.

In the lowest thrust panel of the imbricate zone, the main foliation strikes approximately southeast and dips moderately to the southwest; however, there is a large variation in orientation of this foliation and associated dips (Fig. 3). The main foliation within the schist and quartzite is defined by 
microlithons comprising quartz and rarely feldspar between seams of muscovite (Fig. 7a). Within the siltstone of the Icefield assemblage the main foliation is defined by quartz stringers and graphitic layers. Elongation lineations on the main foliation, which are defined by elongated calcite and quartz grains, plunge approximately $50^{\circ}$ towards $200^{\circ}$ (Fig. 3). Rare $C^{\prime}-S$ shear fabrics are observed in thin sections cut parallel to these lineations and indicate hanging wall motion towards the north-northeast on a foliation plane dipping moderately towards the southwest.

The main foliation in the lowest thrust panel is folded by tight, moderately to steeply plunging folds with an axial planar cleavage that strikes between $270^{\circ}$ and $280^{\circ}$ and dips between $64^{\circ}$ and $70^{\circ}$. They are close, asymmetric folds with angular hinges and thinned limbs. Icefield assemblage siltstone has been locally deformed by a penetrative crenulation cleavage. Kink folds are common in schistose rocks within the imbricate zone (Fig. $7 \mathrm{~b})$.

Brittle deformation overprints the ductile fabrics described above. A 10-20 m-wide, discrete gouge zone is observed within siltstone, phyllite and schist of the Icefield assemblage and is the boundary between the lower thrust panel and its hanging wall. Fault gouge comprises finely-milled rock (dominantly quartz and feldspar) in a clay matrix that has developed a pervasive planar fabric that strikes $125^{\circ}$ and dips approximately $30^{\circ}$ towards the southwest. Locally within the Dollis Creek canyon, this planar fabric has been folded into northeast-verging tight, asymmetric, chevron folds with hinges plunging shallowly to the southeast (Fig. 7c). No lineations or kinematic indicators (aside from the folding mentioned above) were found within the gouge zone. Bullion assemblage marble sits structurally above the gouge zone and remains relatively undeformed (Fig. 7d); however, the marble has been cut by a number of quartz and calcite veins that form three dominant sets. Two of these sets are steeply dipping and range in thickness from $1-5 \mathrm{~cm}$ and the third set is moderately dipping, closely spaced, with an average thickness of $<1 \mathrm{~cm}$. 


\section{Jessie Creek Area}

The Duke River Fault near Jessie Creek is exposed in a narrow valley between steep-sided mountains of the Kluane Ranges (Fig. 1, 4). In this area, the fault is a steep south-dipping structure exhibiting reverse motion. It is the leading edge of an approximately 1500 metre- wide zone of deformation (imbricate zone; Fig. 4) where brittle shear zones overprint ductile deformation. The imbricate zone is developed within the Icefield assemblage and can be divided into two thrust panels, each characterized by a distinct set of structures and map units, and separated by brittle shear zones (Fig. 4).

\section{Wrangellia footwall}

In the Jessie Creek area the footwall of the Duke River Fault comprises light grey, thinly bedded Upper Triassic Chitistone Limestone. The limestone unconformably overlies dark grey to black siltstone and brown sandstone of the Lower Permian Hasen Creek Formation that is exposed in the core of a west plunging antiform (Fig. 4).

\section{Alexander terrane hanging wall}

The geology of the hanging wall of the Duke River Fault in the Jessie Creek area includes two distinct, thrust-bounded stratigraphic successions that make up the imbricate zone and a third succession that comprises Alexander terrane rocks that have not been deformed by the fault. The Silver Creek member of the Icefield assemblage comprises calcareous siltstone interbedded with Triassic ribbon chert (Campbell and Dodds 1990), foliated, maroon and green volcanic conglomerate and rare fossiliferous limestone of unknown age (Cobbett, 2011). These rocks together occupy the lowest thrust panel in the imbricate zone and lie directly above the Duke River Fault (Fig. 4). Rocks in the overlying thrust panel include quartz-feldspar-chlorite phyllonite and schist, calcareous to carbonaceous feldspar- 
muscovite-quartz schist, banded and massive marble and locally micaceous quartzite that have been assigned to the older units of the Icefield assemblage. Rocks occupying both thrust panels are intruded by hornblende-epidote gabbro and ultramafic rocks of probable Early Cretaceous age. In thin sections, the gabbro shows a plagioclase, hornblende, actinolite and epidote mineral assemblage. Rocks that belong to the Alexander terrane south of the imbricate zone include grey, banded marble that contains Ordovician fossils (Cobbett 2011) interlayered with fine- to medium-grained, dark green, basalt composed of plagioclase, actinolite (partly altered to chlorite), clinopyroxene (partly altered to actinolite) and epidote. These rocks have been assigned to the Donjek assemblage and are exposed along a cliffy ridge in the southwestern part of the map sheet (Fig. 4; Cobbett, 2011).

Within the lowest thrust panel of the Duke River Fault imbricate zone (Domain 1), foliation is best displayed in the conglomerate by clasts flattened in a plane that mostly dips moderately to steeply north and northeast. The foliation is not observed in the chert; instead bedding is observed dipping steeply in a variety of directions. The foliation and bedding are tightly folded by west-southwest plunging folds that are subsequently deformed by a later phase of open, north- and northwest-plungingfolds (Fig. 4). Dome and basin fold interference patterns are developed where the hinges of these two fold sets intersect. Within the overlying thrust panel (Domain 2), the dominant phase of deformation is defined by a foliation characterized by seams of muscovite separating microlithons of dominantly dynamically recrystallized quartz and feldspar in quartzite and schist, respectively, and is the main layering seen in marble. The dominant foliation strikes mainly to the east-southeast and dips moderately to the south and is deformed by at least three phases of folding. Rare, rootless, isoclinal folds observed within a single microlithon are evidence of an early phase of folding that has been mostly overprinted by younger structures. Shallow to moderately plunging tight to isoclinal, asymmetric folds are the prominent phase of folds observed within Domain 2. Northwest-plunging crenulation lineations, commonly observed when schistose rocks break along the mica seams, are related to the second phase 
of folding. Late, open folds of a third phase deform the second phase folds and the crenulation lineations. Where crenulation lineations are not folded they plunge moderately towards $295^{\circ}$. Elongation lineations measured on the dominant foliation are defined by elongated calcite, quartz and mica and plunge moderately towards $110^{\circ}$. Rare $C^{\prime}$-S shear fabrics are seen in thin sections cut parallel to elongation lineations (Fig. 8a) indicating top to the northwest, dextral reverse shear. Muscovite grains grow along the dominant foliation and also grow along shear bands (Fig. 8b)

Brittle damage zones comprising closely spaced-fracture sets and discrete zones of cataclasite overprint the ductile structures described above. The Duke River Fault, separating Chitistone Limestone from Icefield assemblage conglomerate, is a zone of fault breccia several metres wide with seams of fault gouge (Fig. 8c). Another brittle feature that separates Domain 1 from Domain 2 roughly parallels Jessie Creek and is best exposed in the far western edge of the map (Fig. 4). Here it is characterized by several cataclastic zones comprising sub-rounded, pebble-sized clasts of siltstone and volcanic material in a clay matrix (Fig. 8d). These zones dip both north-northeast, where Jessie Creek occurs north of the structure, and to the southwest very near where Jessie Creek crosses this structure and begins running south of it.

The upper structural contact of Domain 2 (corresponding with the contact between the Donjek and Icefield assemblages) is characterized by a section of broken up, dark grey, carbonaceous siltstone sitting below cliffy outcrops of laminated marble. The laminations in the marble, the foliations in the siltstone and the contact between these two rock types all dip moderately southwest. Strongly damaged zones characterized by highly folded and fractured rock are common within the Duke River Fault imbricate zone. At Jessie Creek, in the southeast corner of the map, within the upper thrust panel (Domain 2), carbonaceous feldspar-muscovite schist is folded on a centimetre-scale, with near vertical plunging, tight folds and near horizontal, open to tight folds. In the most damaged areas, single layers 
within the schist are not traceable for more than one metre. Crenulation lineations within mica layers are commonly obliquely folded around tight folds. In one location, doubly plunging folds deform a quartzite layer.

\section{Hoge Creek}

Approximately $55 \mathrm{~km}$ to the northwest of the Jessie Creek area, the Duke River Fault is very well exposed in a steep valley occupied by Hoge Creek (Fig. 1, 5). In the Hoge Creek area, the Duke River Fault is the leading edge of a one kilometre wide zone of brittle and ductile deformation that is bound to the north and south by brittle shear zones (Fig. 5). In the Hoge Creek area the hanging wall rocks are imbricated into several thrust panels and one thrust fault cuts up into Wrangellian strata.

\section{Wrangellia footwall}

The footwall of the Duke River Fault in the Hoge Creek area includes conglomerate, limestone and fine to coarse clastic rocks of the Permian Hasen Creek Formation and two gabbro bodies inferred to be Devonian and Early Cretaceous (Fig. 5). The stratigraphically lowest exposed unit in the Hasen Creek Formation is a boulder conglomerate dominated by clasts of medium-grained diorite and gabbro that grades upward into a volcanic breccia comprising very angular volcanic derived clasts in a sandy maroon matrix. The volcanic breccia grades upwards into a grey and brown, pebble conglomerate, then into a medium- to coarse-grained, lithic sandstone, a fossiliferous wackestone, and finally into a banded to massive marble. A strongly deformed gabbro (DSC), observed only in the far western part of the map, is interpreted to be Devonian in age based on lithologic similarities with gabbro bodies that have been dated in the region (Israel et al. 2014). The gabbro is unconformably overlain by the boulder conglomerate of the Hasen Creek Formation. An undeformed medium-grained hornblende gabbro intrudes Hasen Creek conglomerate in the eastern part of the map and is interpreted to be Early 
Cretaceous based on lithologic similarities with the Pyroxenite Creek Suite (Gordey and Makepeace, 2001).

The footwall rocks are deformed by upright, tight folds with hinges oriented northwest/southeast and by an unnamed thrust fault that lies partially below the Duke River Fault. These folds are sub-parallel to the Hoge Creek syncline, a large regional structure found just north of the Hoge Creek area (Read and Monger 1976).

\section{Alexander terrane hanging wall}

The hanging wall of the Duke River Fault is predominantly made up of phyllite, phyllonite, siltstone, marble and basalt of the Icefield assemblage. Beige-colored, medium-grained hornblendebiotite diorite of the Miocene Wrangell suite crops out in the southeast part of the mapped area and roughly delineates the southern boundary of the imbricate zone. The lowest thrust panel in the Duke River Fault zone includes a massive, strongly deformed marble (DTrl4) in the western half of the map (and Hasen Creek rocks in the eastern half). The overlying thrust panel comprises phyllonite characterized by recrystallized feldspar and quartz (DTrl1) and dark grey carbonaceous and calcareous siltstone and phyllite (DTrI2). In the overlying thrust panel, carbonaceous, calcareous, muscovitefeldspar-quartz phyllite and lozenges of grey, banded marble are well exposed south of Hoge Creek. To the south in the structurally highest thrust panel, volcanic breccia and plagioclase-phyric basalt flows (DTrl3) occur with siltstone (DTrl2) and are intruded by diorite (MW) (Fig. 5).

Calcareous and carbonaceous siltstone exhibits a foliation that is dominantly made up of calcite and quartz crystals between layers of clay and other dark, insoluble minerals. A foliation within the phyllite is defined by microlithons of feldspar and dynamically recrystallized quartz between seams of muscovite and within phyllonite by very fine-grained, mildly elongated feldspar, quartz and mica. Siltstone, phyllite and phyllonite are commonly tightly to isoclinally folded within the Duke River Fault 
imbricate zone. Fold hinges are oriented in a variety of directions but broadly can be grouped into northwest-plunging and east-southeast-plunging folds (Fig. 5). Within the east-southeast-plunging group, some folds are asymmetric and verge to the north-northeast but many are symmetric. Within the northwest-plunging group no patterns of vergence or fold style could be ascertained. Crenulation lineations are common within phyllite and are folded around tight and isoclinal folds. Also within phyllite an early foliation is rarely seen within the dominant foliation (Fig. 9a).Four distinct, brittle shear zones overprint the foliation within the imbricate zone and bound the thrust panels. The lowest thrust panel is bounded by a brittle shear zone that separates Hasen Creek conglomerate from Alexander terrane limestone in the western half of the mapped area. This shear zone cuts up into Hasen Creek Formation eastward across the map (Fig. 5). Where this structure deforms Hasen Creek Formation rocks it is characterized as a cataclastic zone that ranges in width from 1 to 5 metres and is composed of wellrounded pebble- and sand-sized clasts of volcanic material. A planar fabric is defined by interlayered sandy sections between coarser-grained layers developed within the cataclastic zone and strikes southeast and dips moderately to the southwest (Fig. 5). Locally at the top of this lowermost thrust panel is a small dike of Wrangell Volcanics (Fig. 5). The overlying thrust panel is bounded by a brittle shear zone that separates phyllite and phyllonite (DTrl1) from limestone (DTrl4) in the west and phyllite and siltstone (DTrl2) of the Icefield assemblage from Hasen Creek sandstone (PHC) in the east (Fig. 5). This shear zone is characterized by clay and sub-angular, pebble-sized fragments of dominantly calcareous siltstone that exhibits planar fabrics that strike southeast and dip moderately to the southwest. The next highest thrust panel is bounded at its base by a 5 to 50 metre thick section of fault gouge that cuts through Icefield assemblage siltstone (DTrl2). The boundary of the structurally highest thrust panel is marked locally by a thrust contact between diorite of the Miocene Wrangell suite and siltstone of the Icefield assemblage (DTrl2), and in part by a thrust contact between basalt (DTrl3) and siltstone (DTrI2; Fig. 5) of the Icefield assemblage. The contact between diorite and siltstone is 
characterized by gouge composed of sub-rounded, sand sized fragments of dominantly quartz in a clay matrix (Fig. 9b). Field observations indicate deformation only affected rocks within ten metres of the contact. Away from the gouge zone, to the south, the diorite body is undeformed (Fig. 9c). This gouge zone strikes approximately $100^{\circ}$ and dips shallowly to the south and lacks any well-developed planar fabrics. Away from the Wrangell suite diorite to the east, the boundary of the structurally highest thrust panel is inferred to follow the contact with the basalt (DTrl3) and siltstone (DTrl2), and to the west is inferred to cut through the basalt. Neither of these sections of the boundary was examined in the field.

Locally, in the west-central part of the map area, a thick section of calcareous siltstone and phyllite is intruded by dikes that are folded, pulled apart and in places completely dismembered (Fig. 9d). In some locations the dikes cross cut the main foliation but are pulled apart parallel to the main foliation in other areas.

\section{Klutlan Glacier Area}

The westernmost exposure of the Duke River Fault in Yukon occurs near the Yukon-Alaska border, approximately $60 \mathrm{~km}$ west-northwest of Hoge Creek (Fig. 1). In the mapped area, the Duke River Fault is a steeply south-dipping reverse fault that places Late Paleozoic, higher metamorphic grade rocks of the Alexander terrane over Wrangellia (Fig. 6). Detailed information is limited due to rugged topography and glaciers and therefore only a brief description and sketch of the geology is provided (Fig. $6)$.

In the Klutlan Glacier area the footwall of the fault comprises folded basalt and sandstone that have been assigned to the Pennsylvanian Station Creek and Permian Hasen Creek Formations, respectively. The hanging wall of the fault comprises a panel of gabbro and foliated leucocratic gabbro that has been assigned to the Devonian Steele Creek Suite and mica schist that has been assigned to the 
Bullion assemblage. South of this panel and in fault contact with the leucocratic gabbro, folded micaceous quartzite and marble have been assigned to the Bullion assemblage.

\section{TIMING OF DEFORMATION ALONG THE DUKE RIVER FAULT}

Seven samples were collected for geochronological analysis to determine timing of deformation along the Duke River Fault. One sample of deformed diorite in the hanging wall of the Duke River Fault zone was dated by the U-Pb zircon CA-TIMS method at Boise State University described in Appendix I. ${ }^{40} \mathrm{Ar} /{ }^{39} \mathrm{Ar}$ analyses of muscovite were performed at the University of British Columbia's Pacific Centre for Isotopic and Geochemical Research (five samples) and at the Geological Survey of Canada in Ottawa, Ontario (one sample). Detailed descriptions of the ${ }^{40} \mathrm{Ar} /{ }^{39} \mathrm{Ar}$ methodologies from both laboratories are presented in Appendix II.

\section{U-Pb Geochronology}

Numerous samples were collected from igneous rocks deformed by the Duke River Fault in order to constrain the minimum age of deformation. One of these samples proved to be dateable using the U$\mathrm{Pb}$ geochronological techniques. Sample 09RC151 is from a medium-grained, biotite-hornblendepyroxene diorite that crops out near Hoge Creek in the hanging wall of the Duke River Fault zone and is deformed into clay and crushed rock within ten metres of the fault (Fig. 9b). Six single zircon grains were analysed, and the four youngest ${ }^{206} \mathrm{~Pb} /{ }^{238} \mathrm{U}$ dates are equivalent with a weighted mean of $15.463+/-$ $0.013 \mathrm{Ma}$ (Fig. 10a; Tables I and II). Two other slightly older dates of $15.500 \pm 0.034$ and $15.504 \pm 0.031$ Ma are interpreted as being from grains with a prolonged magma residence history or that contained inherited components. 


\section{${ }^{40} \mathrm{Ar} /{ }^{39} \mathrm{Ar}$ Geochronology}

${ }^{40} \mathrm{Ar} /{ }^{39} \mathrm{Ar}$ age determinations on rocks along and nearby the Duke River Fault yielded several different ages. Samples were collected in order to constrain the timing of regional metamorphism in the Alexander terrane and ductile movement along the Duke River Fault. Two samples were collected near Klutlan Glacier in the hanging wall of the Duke River Fault in Bullion assemblage mica schist and micaceous quartzite (Cobbett 2011d; Fig. 6). Muscovite that defines the main regional foliation in the mica schist (from sample 08-RC-060-1b) shows a ${ }^{40} \mathrm{Ar} /{ }^{39} \mathrm{Ar}$ age spectrum with a plateau age of $256.5+/-$ 3.7 Ma defined by $76.5 \%$ of the gas released over 5 steps (Fig. 6 and 10b; Tables I and III). Muscovite within the quartzite defines the dominant foliation (from sample 08-RC-071-1) and yielded a ${ }^{40} \mathrm{Ar} /{ }^{39} \mathrm{Ar}$ age spectrum with a plateau age of $254.7+/-5.3$ Ma defined by $88 \%$ of the gas released over 8 steps (Fig. 6 and 10c; Tables I and III).

Muscovite that defines the dominant foliation within the Icefield assemblage rocks in the Duke River Fault imbricate zone near Dollis Creek gave a plateau age of 79.3 +/- 2.5 Ma comprising $78.3 \%$ of the gas released over 6 steps (sample 08-RC-024-1A) (Fig. 3 and10d; Tables I and III). Two other muscovite-bearing samples from the imbricate zone at Dollis Creek were also analyzed. Sample 08-RC024-1B yielded a ${ }^{40} \mathrm{Ar} /{ }^{39} \mathrm{Ar}$ spectrum showing significant ${ }^{40} \mathrm{Ar}$-loss in the low- to mid-temperature heating steps. These steps ranged in age between 62 and $98 \mathrm{Ma}$. The high-temperature steps yielded a pseudoplateau age of $103.5+/-1.7 \mathrm{Ma}$ (30\% of the total ${ }^{39} \mathrm{Ar}$ gas released over 6 steps) (Fig. 3 and 10e; Table I and III). Sample 08-RC-028-1 gave a plateau age of 90.9 +/- $2.1 \mathrm{Ma}(80.8 \%$ of the gas released over 7 mid- to high-temperature steps) (Fig. 3 and10f; Table I and III). Weak foliation in a calcite-altered rock is defined dominantly by muscovite near the Duke River Fault at Jessie Creek (from sample 09-RC063C01). This sample gave a hump-shaped release spectrum from which no plateau age could be determined. On the inverse isochron diagram, the majority of data points plotted along a line 
intersecting the $\mathrm{y}$-axis at $\mathrm{a}^{40} \mathrm{Ar} /{ }^{36} \mathrm{Ar}$ composition of $2797 \pm 1552$. The inverse isochron age for the muscovite $104.8+/-3.7$ Ma defined by $58 \%$ of the ${ }^{39} \mathrm{Ar}$ released ( 7 of 9 heating steps) (Fig. 4 and 10g; Tables I and III).

\section{DISCUSSION}

\section{Kinematic Interpretation}

In all areas, the Duke River Fault zone in its present configuration juxtaposes older rocks of higher metamorphic grade above younger rocks of lower metamorphic grade. Elongation lineations at both Dollis and Jessie creeks are interpreted to record transport direction of ductile movements along the fault. Near Dollis Creek the lineations plunge towards the south-southwest. The C'-S shear fabrics associated with the lineations suggest a thrusting motion. This, together with the orientation of the fault, indicates a nearly orthogonal (slightly dextral oblique) direction of transport (Fig. 11). Near Jessie Creek the lineations plunge shallowly to moderately to the east-southeast and, coupled with associated C'-S shear fabrics, suggest strike-slip motion with a reverse component or an oblique thrust (Fig. 11). Therefore, we interpret that the earlier, ductile phase of Duke River Fault deformation is associated with thrusting that places the Alexander terrane over Wrangellia towards the north-northeast near Dollis Creek and towards the west-northwest near Jessie Creek along the elongation lineation axes. At Hoge Creek, no ductile elongation lineation was observed; therefore, a transport direction was not ascertained. However, Alexander terrane rocks sit structurally above Wrangellia rocks along the Duke River Fault and there are north-northeast vergent asymmetric folds. Both suggest a thrust relationship that is consistent with relationships elsewhere. 


\section{Conditions of faulting}

Evidence collected at several locations along the fault provides insight into the conditions of faulting in both the ductile and brittle regimes. Ultramafic bodies that intrude schist within Domain 1 near Jessie Creek have developed a fabric defined by bands of muscovite and elongate grains of dynamically recrystallized feldspar suggesting deformation at approximately $450^{\circ} \mathrm{C}$ (Price and Cosgrove, 1990).

In both the Dollis Creek and Hoge Creek areas some brittle shear zones and sections of fault gouge are nearly completely altered to clay. For example, in a diorite from within the structurally highest gouge zone at Hoge Creek, all minerals except quartz have been altered to clay. The foliation within siltstone at Dollis Creek is interpreted to have formed by pressure solution processes because it appears that the soluble material has been removed, leaving behind layers of dark insoluble minerals and clay during the forming of stylolites. This suggests fluids percolated through the fault zone when it was active at shallow crustal levels (Warr and Cox 2015; Renard et al. 2000).

\section{Ages of fabric development near the Duke River Fault}

\section{Permian}

Permian ages (ca. 257 to $255 \mathrm{Ma}$ ) obtained from samples near Klutlan Glacier are interpreted to record the age of a regional metamorphic event that affected the Alexander terrane in Yukon. These ages are indistinguishable from Permian (ca. 273 to $260 \mathrm{Ma}$ ) ${ }^{40} \mathrm{Ar} /{ }^{39} \mathrm{Ar}$ cooling ages from metamorphic rocks within the Alexander terrane in southeast Alaska that have been interpreted by Karl et al. (2010) to date a regional metamorphic event. Near Klutlan Glacier the muscovite probably formed during Permian regional metamorphism of the Alexander terrane and was not subsequently recrystallized during deformation along the Duke River Fault. Younger ages in the low-temperature heating steps of 
the Klutlan Glacier samples may reflect partial resetting that could be attributed to fault deformation (Fig. 10b and c). One explanation for this is that the Duke River Fault in this area has not been as deeply exhumed as in the more southern locations. Another possibility is that deformation along the Duke River Fault is represented by several strands, none of which at the Klutlan locality saw enough shear-heating or fluid-flow in the Cretaceous to reset the ${ }^{40} \mathrm{Ar} /{ }^{39} \mathrm{Ar}$ system.

\section{Cretaceous}

The Duke River Fault underwent a protracted period of ductile deformation, which, based on several ${ }^{40} \mathrm{Ar} /{ }^{39} \mathrm{Ar}$ ages, is interpreted to have occurred in the Cretaceous. The dominant foliation preserved in the Duke River Fault imbricate zone is interpreted to be formed by pressure solution processes, growth and/or recrystallization of muscovite and dislocation creep which has resulted in dynamically recrystallized quartz and feldspar grains (Fig. 7a and 8a, b). In all locations mapped along the fault, the fabric developed by these processes has been folded and this folding is interpreted to be a result of movement along the fault.

Near Dollis Creek the main penetrative foliation, asymmetric folds and associated axial planar cleavage developed within the quartz-feldspar schist and crenulation cleavage developed within siltstone are attributed to a phase of ductile deformation along the Duke River Fault. Similarly, near both Jessie and Hoge creeks, metamorphic fabrics, crenulation lineations and folding that deformed both of these structures are all attributed to deformation along the fault. Near Hoge Creek, phyllonite is interpreted to have formed through extensive grain size reduction in response to ductile deformation processes being active over extended periods of time. Muscovite from Dollis and Jessie Creek areas that are interpreted, because of their proximity to the fault zone, to have formed during Duke River Fault deformation give a range of cooling ages from 105 to $79 \mathrm{Ma}$; this suggests ductile motion along the fault is Cretaceous in age (Albian to Cenomanian). 
Near Hoge Creek the dominant foliation, northwest plunging and east-southeast plunging folds are attributed to a phase of ductile deformation along the Duke River Fault. The variation in the orientation of the folds at Hoge Creek suggests they were formed by more than one phase of folding (Fig. 5). This could be explained if the Duke River Fault was active in pulses throughout its ductile phase. In the same area, dikes that have been pulled apart and dismembered are interpreted to be syn- to late kinematic because they cross-cut the ductile foliation in some places and have been pulled apart parallel to the foliation in other places (Fig. 9d).

The Cretaceous ${ }^{40} \mathrm{Ar} /{ }^{39} \mathrm{Ar}$ ages (ca. 105 to $79 \mathrm{Ma}$ ) obtained for muscovite from rocks of the Icefield assemblage within the Duke River Fault imbricate zone are interpreted to date movements along the fault. Muscovite that has grown parallel to both $S$ and $C^{\prime}$ surfaces likely grew during movement along the fault. The presence of dynamically recrystallized feldspar indicates heat from shearing reached $450^{\circ} \mathrm{C}$ or higher which is well above the ${ }^{40} \mathrm{Ar} /{ }^{39} \mathrm{Ar}$ closure temperature for muscovite (Purdy and Jäger 1976; Jäger 1979; Price and Cosgrove 1990).

Based on the quality of the ${ }^{40} \mathrm{Ar} /{ }^{39} \mathrm{Ar}$ spectra for the four Cretaceous samples, $103.5+/-1.7 \mathrm{Ma}$ (from sample 08-RC024-1b) is the preferred minimum age for the main phase of ductile movement along the fault. Although it is based on only $30 \%$ of the total released ${ }^{39} \mathrm{Ar}$ for the sample, the age is not a true plateau age; however, the age is calculated from all high temperatures steps (except for the fusion step) which gave more precise results compared to the other two samples (Fig. 10e). Sample 09RC-063C01 did not yield a plateau age but the inverse isochron age of ca. $105 \mathrm{Ma}$ is indistinguishable from the 103.5 +/- 1.7 Ma pseudoplateau age from sample 08-RC024-1b.

The spectra for muscovite from samples 08-RC-024-1a and 08-RC-028-1 were slightly humpshaped with relatively lower precision, and yielded much younger Late Cretaceous plateau ages. In both samples, high-temperature steps dropped off significantly from the main plateau. The younger ages 
obtained from these samples, and from the low- to mid-temperature steps of 08-RC-024-1b may be attributed to 1) argon loss related to fluids percolating through the deformation zone during or following movement along the Duke River Fault, 2) thermal resetting of fine-grained muscovite that may be related to episodes of high heat flow in and near the Duke River Fault after the main phase of movement (Scaillet et al. 1990), 3) mica growth at various times during prolonged deformation within the Duke River Fault imbricate zone (Kirschner et al. 1996; Hames and Cheney 1997; Dunlap and Kronenberg 2001), or 4) slower cooling of these rocks. The presence of secondary calcite and quartz in most samples collected along the fault suggests that syn- or post-kinematic circulation of fluid within the Duke River Fault imbricate zone may explain the argon loss.

\section{Miocene and later}

Brittle features observed along the Duke River Fault zone overprint ductile fabrics suggesting a reactivation of the fault at shallow crustal levels, above the brittle-ductile transition subsequent to the development of the ductile fabrics. In the Dollis Creek canyon, where Wrangell Volcanics are overridden by the thrust, there are good exposures of fault gouge that overprint and completely destroy earlier structures. Here, the schistose rocks of the Icefield assemblage localize the brittle deformation and have been deformed into crushed rock and locally fault gouge (Fig. 7c). Fracture sets within the Miocene tuff are interpreted to be associated with this late movement along the Duke River Fault as these features are only found within approximately 300 metres of the fault. This suggests that at least some post-Miocene brittle faulting took place. Similarly, Miocene (?) crystal tuff northeast of the Bullion Creek area exhibits clay gouge and brecciated zones near the Duke River Fault (Cobbett 2011) and northwest of Hoge Creek, the Wrangell Volcanics are folded above the Duke River Fault (Dodds and Campbell 1992). 
Within the Jessie Creek area cohesionless damage zones composed of fault breccia, cataclasite and gouge overprint the ductile foliation and are interpreted to be a result of movement along thrust and reverse faults. Near Hoge Creek, brittle shear zones deform the base of a Miocene diorite body, Icefield assemblage and Hasen Creek rocks and clearly overprint ductile fabric.

Furthur evidence that indicates that the Duke River Fault was reactivated in the Cenozoic includes pull-apart basins filled with Oligocene conglomerates that have been mapped near the fault in southwest Yukon (Ridgway et al. 1992; Ridgway and DeCelles 1993). Northwest of Hoge Creek, the Burwash basin occurs between the Duke River Fault and the Denali fault and the Bates Lake basin occurs right along the Duke River Fault north of Dollis Creek (Fig. 1, 11). Our study yielded little evidence that pointed to purely strike-slip movement along the Duke River Fault. These basins may be attributed to other, unidentified strike-slip faults in the area or strike-slip motion along the Denali fault.

Whether or not the Duke River Fault was active continuously or intermittently is not known. It is interpreted as being a deep, crustal scale structure that extended below the brittle-ductile transition zone in the Albian to Cenomanian because of the nature of the fault fabrics and the width and extent of the fault zone. The ductile portions of the fault were exhumed into the brittle regime by the Miocene. Either the fault was progressively deforming from Cretaceous to Miocene time and was gradually exhumed or there was a pulse of ductile deformation in the Cretaceous and then a period of erosion and exhumation with a reactivation at higher level in the crust in the Miocene.

\section{Regional considerations}

From northern Washington to Juneau, Alaska, regional Cretaceous (Albian to Cenomanian) transpression affected a $1200 \mathrm{~km}$ long section of the Cordillera mainly along the western edge of the Coast Plutonic Complex (Crawford et al. 1987; Rubin et al. 1990; McClelland and Mattinson 2000; Rusmore et al. 2000; Angen et al. 2014). Evidence includes west-vergent thrust faults and sinistral strike 
slip shear zones mapped at numerous locations along the western edge of the Coast Plutonic Complex that are coeval with east-vergent thrust faults that occur east of the Coast Plutonic Complex (Crawford et al. 1987; Evenchick, 1991; Journeay and Friedman 1993; Rusmore and Woodsworth 1994; McClelland and Mattinson 2000; Evenchick et al., 2007; Israel et al. 2013; Angen et al. 2014).

Similarities in the age of deformation along both the east and west-verging thrust faults with the ${ }^{40} \mathrm{Ar} /{ }^{39} \mathrm{Ar}$ ages from the Duke River Fault zone suggest the fault may form part of the northern end of this phase of oblique shortening and is best correlated with the structures that represent the phase of tectonism characterized by dextral transpression. The timing of this phase may be slightly younger in the south than movement along the Duke River Fault. In all cases, as with the Duke River Fault, the thrust faults juxtapose rocks of relatively higher metamorphic grade with rocks characterised by lower grade.

Several workers have identified large-scale sinistral strike-slip and sinistral oblique thrust faults of Cretaceous age within the Coast Plutonic Complex, separating the Insular terranes from the Intermontane terranes (Schiarizza et al., 1997; Umhoefer et al., 2002; Chardon et al., 2003; Evenchick, 2006; Israel et al., 2006; 2013; Angen et al., 2014). Similarly aged dextral faults are observed separating the Intermontane terranes from more inboard terranes (Gabrielse et al., 2006 and references therein). This dichotomy in kinematics led some researchers to propose a model involving large-scale tectonic escape, where the Intermontane terranes (as a coherent block) moved northward with respect to the bounding North American plate to the east and the Insular terranes to the west (Fig. 12a; Umhoefer, 2003; Nelson et al., 2013; Angen et al., 2014). A problem with this model is that tectonic escape is generally associated with continent-continent type collisional orogens (Molnar and Tapponnier, 1975; Burke and Sengor, 1986), and as Angen et al., (2014) point out, there is a lack of evidence for large-scale Cretaceous accretionary events. The new data from the Duke River fault suggests that there was a dramatic compressional event that provides further evidence for the escape model. 
Several large sedimentary basins (Gravina-Nutzotin-Kahiltna-Dezadeash) developed between the Insular and Intermontane terranes in the Middle to Late Jurassic following initial accretion of the Insular terranes, presumably during a period of transtentional tectonics (McClelland et al., 1992; van der Heyden, 1992; Umhoefer et al., 2002; Evenchick, 2006). This period of transtension was followed by Early Cretaceous sinistral transpression that slowly transitioned into more orthogonal compression and dextral transpression later in the Cretaceous (Engebretson et al., 1985; Schiarizza et al., 1997; McClelland and Mattinson, 2000; Israel et al., 2013; Angen et al., 2014). We suggest that deformation observed along the Duke River fault is the result of orthogonal, dextral transpressive tectonic interaction between the Insular and Intermontane terranes. The 're-accretion' of the Insular terranes to the margin of the Intermontane terranes would be the accretionary event that appears to be lacking in the tectonic escape model (Fig. 12b). The overall kinematics at the time would have been dextral transpressive; however, sinistral kinematics on faults between the Insular and Intermontane terranes existed likely in response to the elevated thermal environment of the Coast Plutonic Complex, due to the voluminous Cretaceous plutons (Woodsworth et al., 1991; Hollister and Crawford, 1996; Hollister and Andronicos, 2006). The Coast Plutonic Complex was a thermally weakened zone that allowed for escape of the Intermontane terranes northward between two coherent tectonic blocks, the Insular terranes and North America (Fig. 12b). The Duke River fault, and associated structures, accommodated the dextral transpressive kinematics within the 'colder' and stiffer tectonic collider

Reactivation of the Duke River Fault occurs during the collision of the Yakutat microplate with North America. The Yakutat microplate has been shown to have moved northwestwards with the Pacific Plate along margin-parallel strike-slip faults until it reached the Gulf of Alaska in the Miocene at which point it began to underthrust beneath the North American Plate in southern Alaska (Plafker 1994; Bruhn 2004). Global Positioning System (GPS) motion vectors show that some of the present day deformation related to the Yakutat microplate collision is causing the southwest corner of the Yukon to move 
towards the north-northeast (Mazzotti 2002). The Duke River Fault is favourably oriented to accommodate northeast-southwest compression by reverse slip. Micro-seismicity recorded along the Duke River Fault in the southwest Yukon suggests the fault accommodates part of the active uplift of the St. Elias Mountains (Power 1988; Page 1991).

\section{CONCLUSIONS}

The Duke River Fault mostly separates the Alexander terrane from Wrangellia in southwest Yukon. The thrust fault places pervasively foliated Alexander terrane rocks over mildly deformed rocks of Wrangellia. Elongation lineations from within the fault zone suggest this fault was a dextral oblique to orthogonal thrust fault in the Cretaceous. ${ }^{40} \mathrm{Ar} /{ }^{39} \mathrm{Ar}$ dating of muscovite grains from deformed rocks within the Duke River Fault zone range in age from 79 Ma to $105 \mathrm{Ma}$. Rocks at least as young as $15.5 \mathrm{Ma}$ have been affected by brittle deformation clearly showing the Duke River Fault has accommodated shortening since the Miocene (Langhian).

\section{ACKNOWLEGMENTS}

Support from the Yukon Geological Survey was essential in all stages of this project, from the design stages through to the submission of this paper. The survey provided funding for all field logistics and some analytical work. Additional analytical funding was provided by the GEM Cordillera Program at the Geological Survey of Canada. Janet Gabites is gratefully acknowledged for Ar/Ar analytical work and data reduction at PCIGR at the University of British Columbia. Many geoscientists, in addition to the coauthors of this paper, provided mentorship and guidance during the course of this project, including Lori Kennedy, Cees van Staal and Don Murphy. This is ESS Contribution number / Numéro de contribution du SST: 20160155 and YGS contribution number 027. 


\section{REFERENCES}

Angen, J.J., van Staal, C.R., Lin, S., Nelson, J. L., Mahoney, J.B., Davis, D.W., McClelland, W.C. 2014. Kinematics and timing of shear zone deformation in the western Coast Belt: evidence for midCretaceous orogen parallel extension. Journal of Structural Geology, 68 (B): 273-299.

Beranek, L.P., Staal, C.R.v., Gordee, S.M., McClelland, W.C., Israel, S., and Mihalynuk, M. 2012. Tectonic Significance of Upper Cambrian-Middle Ordovician Mafic Volcanic Rocks on the Alexander Terrane, Saint Elias Mountains, Northwestern Canada. The Journal of Geology, 120 (3): 293-314. doi: $10.1086 / 664788$.

Beranek, L.P., Staal, C.R.v., McClelland, W.C., Joyce, N., Israel, S. 2014. Late Paleozoic assembly of the Alexander-Wrangellia-Peninsular composite terrane, Canadian and Alaskan Cordillera. Geological Society of America Bulletin, 126 (11/12): 1531-1550. doi: 10.1130/31066.1.

Bruhn, R.L.P., T.L.; Plafker, G.; Serpa, L. 2004. Deformation during terrane accretion in the Saint Elias orogen, Alaska. Geological Society of America Bulletin, 116 (7/8): 771-787. doi: 10.1130/B25182.1.

Burke, K., Sengor, A.M.C., 1986. Tectonic escape in the evolution of the continental crust. In: Barazangi, M., Brown, L. (Eds.), Reflection Seismology, Continental Crust, American Geophysical Union Special Publication, 14: 41-51.

Chardon, D., 2003. Strain partitioning and batholith emplacement at the root of a transpressive magmatic arc. Journal of Structural Geology, 25: 91-97.

Cobbett, R. 2011. Timing and kinematics of the Duke River Fault; insights into the evolution of the Insular terrane, southwest Yukon. M.Sc. thesis, Department of Earth and Ocean Sciences, University of British Columbia, Vancouver, BC, $140 \mathrm{p}$.

Cobbett, R. 2013a. Bedrock geology along the Duke River Fault near Squaw Creek, Yukon and British Columbia (part of NTS 115A/03 and 114P/14) (1:10 000 scale). Yukon Geological Survey, Open File 2013-1.

Cobbett, R. 2013b. Bedrock geology along the Duke River Fault near Jessie Creek, Yukon (part of NTS 115B/16) (1:10 000 scale). Yukon Geological Survey, Open File 2013-3.

Cobbett, R. 2013c. Bedrock geology along the Duke River Fault near Hoge Creek, Yukon (part of NTS 115B/16) (1:10 000 scale). Yukon Geological Survey, Open File 2013-6.

Cobbett, R. 2013d. Bedrock geology along the Duke River Fault near Klutlan Glacier, Yukon (part of NTS 115F/07) (1:10 000 scale). Yukon Geological Survey, Open File 2013-4.

Colpron, M., Nelson, J. L., Murphy, D.C. 2007. Northern Cordilleran terranes and their interactions through time. Geological Society of Amercia Today, 17 (4/5): 4-7. doi: 10.1130/GSAT01704-5A.1

Coney, P.J., Jones, D.L., and Monger, J.W.H. 1980. Cordilleran suspect terranes. Nature, 288 (27 November 1980): 329-333.

Crawford, M.L., Hollister, L.S., and Woodsworth, G.J. 1987. Crustal deformation and regional metamorphism across a terrane boundary, Coast Plutonic Complex, British Columbia. Tectonics 6(3): 343-361.

Dodds, C.J., and Campbell, R.B. 1992. Overview, legend, and mineral deposit tabulations for geology of SW Kluane Lake (115G and G(E1/2)), Mount Saint Elias (115B and C(E1/2)), SW Dezadeash (115A), NE Yakutat (1140), and Tatshenshini (114P) map areas, Yukon Territory and British Columbia. Geological Survey of Canada, Open Files 2188-2191. p. 85.

Dunlap, W., and Kronenberg, A. 2001. Argon loss during deformation of micas: constraints from laboratory deformation experiments. Contributions to Mineralogy and Petrology, 141(2): 174185. doi: $10.1007 / \mathrm{s} 004100000217$. 
Eisbacher, G.H. 1976. Sedimentology of the Dezadeash flysch and its implications for strike-slip faulting along the Denali fault, Yukon Territory and Alaska. Canadian Journal of Earth Sciences, 13: 14951513.

Engebretson, D.C., Cox, A., Gordon, R.G., 1985. Relative Motions between Oceanic and Continental Plates in the Pacific Basin. Geological Society of America Special Papers 206: 1-59.

Evenchick, C.A. 1991. Geometry, evolution, and tectonic framework of the Skeena Fold Belt, north central British Columbia. Tectonics 10 (3): 527-546.

Evenchick, C.A., Mustard, P.S., McMechan, M.E., Ferri, F., Ritcey, D.H., Smith, G.T., 2006. Compilation of geology of Bowser and Sustat Basins draped on shaded relief map, north-central British Columbia. Geological Survey of Canada, Open File 5313, and British Columbia Ministry of Energy, Mines and Petroleum Resources, Petroleum Geology Open File 2006-1, scale: 1:500,000.

Evenchick, C.A., McMechan, M.E., McNicoll, V.J., Carr, S.D. 2007. A synthesis of the Jurassic-Cretaceous tectonic evolution of the central and southeastern Canadian Cordillera: Exploring link across the orogen. Geological Society of America Special Papers 433: 117-145.

Gabrielse, H., Murphy, D.C., and Mortensen, J.K. 2006. Cretaceous and Cenozoic orogen-parallel displacements, magmatism and paleogeography in the northern Canadian Cordillera. In Paleogeography of the North American Cordillera: Evidence For and Against Large-Scale Displacements. Edited by J. Haggart and J.W.H. Monger and R. Enkin. Geological Association of Canada, Special Paper 46: 255-276.

Gabrielse, H., and Yorath, C.J. 1991. Tectonic synthesis, Chapter 18. In Geology of the Cordilleran Orogen in Canada. Edited by H. Gabrielse and C.J. Yorath. Geological Survey of Canada. pp. 677-705.

Gardner, M.C., Bergman, S.C., Cushing, G.W., MacKevett, E.M., Plafker, G., Campbell, R.B., Dodds, C.J., McClelland, W.C., and Mueller, P.A. 1988. Pennsylvanian pluton stitching of Wrangellia and the the Alexander Terrane, Wrangell Mountains, Alaska. Geology, 16(11): 967-971.

Gehrels, G.E., 2001. Geology of the Chatham Sound region, southeast Alaska and coastal British Columbia. Canadian Journal of Earth Sciences, 38: 1579-1599.

Gehrels, G.E., and Berg, H.C., 1992. Geologic map of southeaster Alaska. US Geological Survey.

Gehrels, G.E., Saleeby, J.B. 1987. Geologic Framwork, tectonic evolution, and displacement history of the Alexander terrane. Tectonics, 6 (2): 151-173.

Gordey, S.P., and Makepeace, A.J. (comp) 2001. Yukon Territory. Indian and Northern Affairs Canada/Department of Indian and Northern Development: Exploration and Geological Services Division, Open File 2001-1.

Hames, W.E., and Cheney, J.T. 1997. On the loss of 40Ar* from muscovite during polymetamorphism. Geochima et Cosmochimica Acta, 61(18): 3863-3872. doi: http://dx.doi.org/10.1016/S00167037(97)00207-X.

Hollister, L.S., Andronicos, C., 2006. Formation of new continental crust in Western British Columbia during transpression and transtension. Earth Planet Science Letters, 249: 29-38.

Israel, S., Beranek, L., Friedman, R.M., and Crowley, J.L. 2014. New ties between the Alexander terrane and Wrangellia and implications for North America Cordilleran evolution. Lithosphere, 4 (4): 270-276.

Israel, S., and Cobbett, R. 2008. Kluane Ranges bedrock geology, White River area (Parts of NTS 115F/9, 15 and 16; 115G/12 and 115K/1, 2). In Yukon Exploration and Geology 2007 Edited by D.S. Edmond, L.R. Blackburn, R.P. Hill, and L.H. Weston. Yukon Geological Survey. pp. 153-167.

Israel, S., Cobbett, R., and Fozard, C. 2007. Bedrock geology of the Miles Ridge area, Yukon (parts of NTS $115 \mathrm{~F} / 15,16$ and 115K/1, 2) (1:50,000 scale). Yukon Geological Survey, Open File 2007-7.

Israel, S., Tizzard, A.M., and Major, J. 2006. Bedrock geology fo the Duke River area, parts of NTS $115 \mathrm{G} / 2,3,4,6$ and 7, southwest Yukon. In Yukon Exploration and Geology 2005. Edited by D.S. Emond and G. Bradshaw and L.L. Lewis and L.H. Weston. Yukon Geological Survey. pp. 139-154. 
Israel, S., and van Zeyl, D. 2005. Preliminary geology of the Quill Creek map area, southwest Yukon, parts of NTS 115G/5, 6, 12. In Yukon Exploration and Geology 2004. Edited by D.S. Emond and L.L. Lewis and G. Bradshaw. Yukon Geological Survey. pp. 129-146.

Israel, S.A., Kennedy, L.A., and Friedman, R.M. 2013. Strain partitioning in accretionary orogens, and its effects on orogenic collapse: Insights from western North America. Geological Society of America Bulletin, 125(7-8): 1260-1281.

Jäger, E. 1979. Introduction to geochronology. In Lectures in isotope geology. Springer. pp. 1-12. Kirschner, D.L., Cosca, M.A., Masson, H., and Hunziker, J.C. 1996. Staircase 40Ar/39Ar spectra of fine-grained white mica: Timing and duration of deformation and empirical constraints on argon diffusion. Geology 24: 4.

Journeay, J.M., and Friedman, R.M. 1993. The Coast Belt thrust system: evidence of Late Cretacreous shortening in southwest British Columbia. Tectonics, 12 (3): 756-775.

Kalbas, J.L., Freed, A.M., Ridgeway, K.D. 2008. Contemporary Fault Mechanics in Southern Alaska. Active Tectonics and Seismic Potential of Alaska Geophysical Monograph Series, 179: 321-336.

Kapp, P.A., and Gehrels, G.E., 1998. Detrital zircon contraints on the tectonic evolution of the Gravina belt, southeastern Alaska. Canadian Journal of Earth Sciences, 35: 253-268.

Karl, S.M., layer, P.W., Haeussler, P.J., and Murchey, B.L. 2010. The Cannery Formation - Devonian to Early Permian arc-marginal deposits within the Alexander Terrane, Southeast Alaska. In Dumoulin, J.A., and Galloway, J.P., eds., Studies by the U.S. Geological Survey in Alaska, 20082009: U.S. Geological Special Paper 1776-B, 45 p.

Kirschner, D.L., Cosca, M.A., Masson, H., and Hunziker, J.C. 1996. Staircase 40Ar/39Ar spectra of finegrained white mica: Timing and duration of deformation and empirical constraints on argon diffusion. Geology, $24: 4$.

Lowey, G. 1992. Variation in bed thickness in a turbidite succession, Dezadeash Formation (JuraCretaceous), Yukon, Canada: evidence of thinning-upward and thickening-upward cycles. Sedimentary Geology, 78: 217-232.

Lowey, G. 1998. A new estimate of the amount of displacement on the Denali Fault system based on the occurence of carbonate megaboulders in the Dezadeash Formation (Jura-Cretaceous), Yukon, and the Nutzotin Mountains sequence (Jura-Cretaceous), Alaska. Bulletin of Canadian Petroleum Geology, 46(3): 379-386.

MacKevett, E.M., and Jones, D.L. 1975. Relations between Alexander and Taku-Skolai terranes in McCarthy quadrangle. Geological Survey Research 1975; U.S. Geological Survey Proffessional Paper. 975: pp. 69.

Manuszak, J.D., Ridgway, J.M., Trop, J.M., Gehrels, G.E. 2007. Sedimentary record of the tectonic growth of a collisional continental margin: Upper Jurassic-Lower Cretaceous Nutzotin Mountains sequence, eastern Alaska Range, Alaska. The Geological Society of America, Tectonic Growth of a Collisonal Continental Margin: Crustal Evolution of Southern Alaska(Special Paper 431): 345377.

Mazzotti, S.H., R.D. 2002. Yakutat collision and strain transfer across the northwen Canadian Cordillera. Geological Society of America, 30(6): 4.

McClelland, W.C., and Gehrels, G.E. 1990. The Duncan Canal shear zone: a right-lateral shear zone of Jurassic age along the inboard margin of the Alexander terrane. Geological Society of America Bulletin, 102: 1378-1392.

McClelland, W.C., Gehrels, G.E., and Saleeby, J.B. 1992. Upper Jurassic-Lower Cretaceous basinal strata along Cordilleran margin: Implications for the accretionary history of the Alexander-WrangelliaPeninsular terrane. Tectonics, 11: 823-835.

McClelland, W.C., and Mattinson, J.M. 2000. Cretaceous-Tertiary evolution of the western Coast Mountains, central southeastern Alaska. In Tectonics of the Coast Mountains in southeast Alaska 
and British Columbia. Edited by H.H. Stowell and W.C. McClelland. Geological Society of America, pp. 159-182.

Molnar, P., Tapponnier, P., 1975. Cenozoic tectonics of Asia: effects of a continental collision. Science, 189: 419-426.

Monger, J.W.H., and Price, R.A. 1979. Geodynamic evolution of the Canadian Cordillera - Progress and problems. Canadian Journal of Earth Sciences, 16: 770-791.

Murphy, D.C., Mortensen, J.K., and van Staal, C.R. 2009. 'Windy-McKinley' terrane, western Yukon: new data bearing on its composition, age, correlation and paleotectonic settings. In Yukon Exploration and Geology. Edited by L.H. Weston and L.R. Blackburn and L.L. Lewis. Yukon Geological Survey. pp. 195-209.

Muller, J.E. 1967. Kluane Lake Map Area, Yukon Territory (115G, 115F, 115E1/2). Geological Survey of Canada, Memoir 340: 137.

Nelson, J., Colpron, M., and Israel, S. 2013. The cordillera of British Columbia, Yukon and Alaska: tectonics and metallogeny. Tectonics, metallogeny and discovery: the North American Cordillera and similar accretionary settings. Edited by M. Colpron, T. Bissig, BG Rusk, and J. Thompson. Society of Economic Geologists, Special Publication, 17: 53-110.

Page, R.A.B., N.N.; Lahr, J.C.; Pulpan, H. 1991. Seismicity of continental Alaska, In Slemmons, D.B., Engdahl, E.R., Zoback, M.D., and Blackwell, D.D., eds., Neotectonics of North America: Boulder, Colorado. Geological Society of America, 1(Decade Map).

Plafker, G., Hudson, T., Richter, D.H. 1977. Preliminary observations on the late Cenozoic displacements along the Totschunda and Denali fault systems. Blean, K.L., ed., The United States Geological Survey in Alaska; Accomplishments during 1976: U.S. Geological Survey Circular 751-B: 67.

Plafker, G.M., J.C.; Winkler, G.R. 1994. Geology of the southern Alaska margin, in The Geology of North America, vol. G1, The Geology of Alaska, edited by G. Plafker and H.C. Berg. Geological Society of America(TC3001): 14.

Power, M.A. 1988. Microearthquake seismicity on the Duke River, Denail fault system. Edited by C.G. Survey. Exploration and Geological Services Division, Yukon, Indian and Northern Affairs Canada, Yukon Geology. pp. 61-68.

Price, N.J., and Cosgrove, J.W. 1990. Analysis of geological structures. Cambridge University Press.

Read, P.B., and Monger, J.W.H. 1976. Pre-Cenozoic volcanic assemblages of the Kluane and Alsek Ranges, southwestern Yukon Territory. Geological Survey of Canada, Open File 381. p. 96.

Purdy, J.W., and Jäger, E. 1976. K-Ar ages on rock-forming minerals from the Central Alps. Università di Padova.

Read, P.B., and Wheeler, J.O. 1976. Geology of Lardeau W/2 (82K W/2). Geological Survey of Canada.

Renard, F., Gratier, J., and Jamtveit, B. 2000. Kinetics of crack-sealing, intergranular pressure solution, and compaction around active faults. Journal of Structural Geology 22: 1397-1407.

Richter, D.H., Smith, J.G., Lanphere, M.A., Dalrymple, B.L., Reed, B.L., Shew, N. 1990. Bulletin of Volcanology, 53: 29. doi:10.1007/BF00680318

Ridgway, K.D., and DeCelles, P.G. 1993. Stream-dominated alluvial fan and lacustrine depositional systems in Cenozoic strike-slip basins, Denali fault system, Yukon Territory, Canada. Sedimentology, 40: 21.

Ridgway, K.D., DeCelles, P.G., Cameron, A.R., and Sweet, A.R. (eds). 1992. Cenozoic syntectonic sedimentation and strike-slip basin development along the Denali fault system, Yukon Territory. In Yukon Geology 3; Exploration and Geological Services Division, Yukon, Indian and Northern Affairs Canada: 1-26

Ridgway, K.D., Trop, J.M., Nokelberg, W.J., Davidson, C.M., and Eastham, K.R. 2002. Mesozoic and Cenozoic tectonics of the eastern and central Alaska Range: Progressive basin development and deformation in a a suture zone. Geological Society of America Bulletin, 114(12): 1480-1504. 
Rubin, C.M., Saleeby, J.B., Cowan, D.S., Brandon, M.T., and McGroder, M.F. 1990. Regionally extensive mid-Cretaceous west-vergent thrust system in the northwestern Cordillera: Implications for continent-margin tectonism. Geology, 18(3): 276-280.

Rusmore, M.E., and Woodsworth, G.J. 1994. Evolution of the eastern Waddington thrust belt and its relation to the mid-Cretaceous Coast Mountains arc, western British Columbia. Tectonics, 13(5): 1052-1067.

Rusmore, M.E., Woodsworth, G.J., and Gehrels, G.E. 2000. Late Cretaceous evolution of the eastern Coast Mountains, Bella Coola, British Columbia. In Tectonics of the Coast Mountains, southeastern Alaska and British Columbia. Edited by H.H. Stowell and W.C. McClelland. Geological Society of America Special Paper 343, Boulder, Colorado. pp. 89-105.

Scaillet, S., Feraud, G., Lagabrielle, Y., Ballevre, M., Ruffet, G. 1990. 40Ar/39Ar laser-probe dating by step heating and spot fusion of phengites from the Dora Maira nappe of western Alps, Italy. Geology, 18: 741-744.

Schiarizza, P., Gaba, R.G., Glover, J.K., Garver, J.I., Umhoefer, P.J., 1997. Geology and mineral occurrences of the Taseko-Bridge River area. British Columbia, Geological Survey Branch. Bulletin, 100: 291

Sharp, R.P. 1943. Geology of the Wolf Creek area, St. Elias Range, Yukon Territory. Bulletin of the Geological Society of America, 54:625-650.

Smith, J.G., and MacKevett, E.M. 1970. The Skolai Group in the McCarthy B-4, C-4 and C-5 quandrangles, Wrangell Mountains, Alaska. U.S. Geological Survey, Bulletin 1274-Q.

Umhoefer, P. J., 2003, A model for the North America Cordillera in the Early Cretaceous: Tectonic escape related to arc collision of the Guerrero terrane and a change in North America plate motion, in Johnson, S. E., Paterson, S., R, Fletcher, J. M., Girty, G. H., Kimbrough, D., and Martin-Barajas, A., eds., Tectonic evolution of northwestern Mexico and the southwestern USA, Geological Society of America Special Paper 374, p. 117-134.

Umhoefer, P. J., Schiarizza, P., and Robinson, M., 2002, Relay Mountain Group, Tyaughton-Methow basin, southwest British Columbia: a major Middle Jurassic to Early Cretaceous terrane overlap assemblage: Canadian Journal of Earth Sciences, v. 39, p. 1143-1167.

van der Heyden, P. 1992. A Middle Jurassic to early Tertiary Andean-Sierran arc model for the Coast Belt of British Columbia. Tectonics, 11: 82-97.

Warr, L.N., and Cox, S. 2015. Clay mineral transformations and weakening mechanisms along the Alpine Fault, New Zealand. In The Nature and Tectonic Significance of Fault Zone Weakening. Edited by Holdsworth, R.E., Strachan, R.A., Magloughlin, J.F., and Knipe, R.J. Geological Society, London, Special Publications, 186: 85-101.

Woodsworth, G.J., Anderson, R.G., Armstrong, R.L., 1991. Plutonic Regimes. In: Gabrielse, H., Yorath, C.J., (Eds.), Geology of Canada, Geology of the Cordilleran Orogen in Canada, vol. 4. Geological Survey of Canada, Ottawa, pp. 491-531 
Tables:

Table I: Geochronology sample location and summary of ages

Table II: U-Pb Isotopic data for Wrangell Suite.

Table III: ${ }^{40} \mathrm{Ar} /{ }^{39} \mathrm{Ar}$ data from samples within the Duke River Fault imbricate zon 
Figures:

Figure 1. Terrane map of northern Cordillera in western Canada and Alaska. Inset map shows terranes of southwest Yukon highlighting the Duke River Fault. Red squares show approximate location of mapped areas.

Figure 2. Regional stratigraphy of southwest Yukon.

Figure 3. Geologic map and cross section of Duke River Fault near Dollis Creek. Map legend for Dollis Creek, Jessie Creek, Hoge Creek and Klutlan Glacier areas. Structural data from the Dollis Creek area presented in equal area, lower hemisphere projection stereonets. Map area included in the imbricate zone stereonet is shown on the cross sections. Poles to foliations from within the imbricate zone have been contoured using a $1 \%$ function. The footwall cross section includes the entire area to the northeast of the Duke River Fault. See stereonet legend for symbol explanation. Note: Contour lines in Yukon are every 100 feet and in British Columbia are every 20 metres.

Figure 4. Geologic map and cross section of Duke River Fault near Jessie Creek (see Figure 3 for legend). Structural data from the Jessie Creek area presented in equal area, lower hemisphere projection stereonets. See stereonet legend for symbol explanation.

Figure 5. Geologic map and cross sections of the Duke River Fault near Hoge Creek (see Figure 3 for legend). Structural data collected near Hoge Creek presented on equal area, lower hemisphere stereonets. See stereonet legend for symbol explanation.

Figure 6. Geologic sketch of Duke River Fault near Klutlan Glacier. Figure 3 can be used to identify age of units and map symbols.

Figure 7. Photos from Dollis Creek area. a) Microphotograph of calcareous, quartz-muscovite schist from within the Duke River Fault imbricate zone near Dollis Creek. Foliation is made up of seams of muscovite between microlithons of dominantly quartz and calcite. b) Kink folds within Icefield assemblage schist from the imbricate zone. Photo is looking north and green tool in the right of the photo is $12 \mathrm{~cm}$ long. c) Fault gouge within the Duke River Fault imbricate zone that has developed a planar fabric that was subsequently folded. Photo is looking south with a rock hammer for scale (head of hammer is $15 \mathrm{~cm}$ wide). d) Bullion assemblage (SDB) carbonate sitting structurally above Icefield assemblage siltstone and phyllite (DTrl) that has been in part deformed into fault gouge. Photo is looking southwest across Squaw Creek canyon.

Figure 8. Photos from Jessie Creek area. a) Microphotograph of sample collected from within the Duke River Fault imbricate zone of quartz-feldspar-muscovite phyllite deformed into shear bands. Dashed line traces S-fabric and solid line traces $C^{\prime}$-fabric suggesting sinistral kinematics. b) Microphotograph of sample collected from within the Duke River Fault imbricate zone of quartz-muscovite-calcite schist deformed into shear bands. Dashed line traces S-fabric and solid line traces $C^{\prime}$ - fabric. White circle highlights grain of muscovite that has grown along the $C^{\prime}$ fabric. c) Duke River Fault (black line) 
juxtaposing Icefield assemblage (DTrl) volcanic conglomerate against Chitistone Limestone (uTrC) along steep, south-dipping reverse fault. View looking to the east. White arrow points to fault gouge. d) Photo looking west at Icefield assemblage. Cataclastic zone on the left (black outline) deforms volcanic conglomerate (DTrl7). Cataclastic zone on the right (white outline) deforms siltstone (DTrl8) and a felsic dike. Note the lozenge-shaped sections of the pulled apart dike. Person near the bottom and middle of the photo, circled to show scale.

Figure 9. Photos from Hoge Creek area. a) Early foliation traced with red lines between dominant foliation traced with white lines in phyllite of unit DTrI1. b) Photo looking southeast at gouge zone comprising rounded-quartz grains in clay matrix. Blocky rock above gouge is part of the undeformed Miocene Wrangell diorite. Contact between gouge and diorite strikes approximately $100^{\circ}$ and dips shallowly to the south. c) Microphotograph of undeformed Miocene Wrangell diorite approximately 1 kilometre away from the gouge zone. Bt- biotite, fsp-feldspar, px-pyroxene. d) Felsic dike cutting foliation (white solid line) and pulled apart by foliation (white arrow).

Figure 10. a) Plot of ${ }^{206} \mathrm{~Pb} /{ }^{238} \mathrm{U}$ dates from single grains of zircon analyzed by the CA-TIMS method. Plotted with Isoplot 3.0 (Ludwig, 2003). Error bars are at 2 sigma. Weighted mean date is shown by the grey box behind the error bars. Error bars in white are not included in the weighted mean calculation. MSWD = mean square weighted deviation. pof = probability of fit. b) ${ }^{40} \mathrm{Ar} /{ }^{39} \mathrm{Ar}$ age spectrum for muscovite that defines the regional foliation in schist found at Klutlan Glacier (sample 08-RC-060-1b). c) ${ }^{40} \mathrm{Ar} /{ }^{39} \mathrm{Ar}$ age spectrum for muscovite that defines the main regional foliation in micaceous quartzite at Klutlan Glacier (sample 08-RC-071-1). d) ${ }^{40} \mathrm{Ar} /{ }^{39} \mathrm{Ar}$ age spectrum for muscovite that defines the main foliation in schist found within the Duke River Fault at Dollis Creek (sample 08-RC-024-1A). e) ${ }^{40} \mathrm{Ar} /{ }^{39} \mathrm{Ar}$ age spectrum for muscovite that defines the main foliation in schist found within the Duke River Fault at Dollis Creek (sample 08-RC-024-1B). f) ${ }^{40} \mathrm{Ar} /{ }^{39} \mathrm{Ar}$ age spectrum for muscovite that defines the main foliation in schist found within the Duke River Fault at Dollis Creek (sample 08-RC-028-1). g) ${ }^{40} \mathrm{Ar} /{ }^{39} \mathrm{Ar}$ age spectrum and inverse isochron plot for muscovite that defines the main foliation in phyllite found within the Duke River Fault at Jessie Creek (sample 09-RC-063C01). Note: for all ${ }^{40} \mathrm{Ar} /{ }^{39} \mathrm{Ar}$ samples, plateau steps are light, rejected steps are dark, box heights are $2 \sigma$, line with double arrows indicates plateau or pseudoplateau regions.

Figure 11. Map of southwest Yukon showing study areas (red boxes), transport direction of the Duke River Fault (orange and black arrows) and Eocene-Oligocene strike-slip basins in the vicinity of the Duke River Fault (red polygons). AX - Alexander terrane, WR - Wrangellia, KS - Kluane Schist, YT - Yukon Tanana terrane, CG - Chugach, YA- Yakutat, TrJ - metamorphic rocks, Nab - North America basinal, SM - Slide Mountain, ST - Stikinia, QN - Quesnellia.

Figure 12: a) Map of Canadian and Alaskan Cordillera showing mid-Cretaceous tectonics and 'escape' of Intermontane terranes to the northwest (modified from Nelson et al, 2013). b) Schematic drawing that outlines change in regional kinematics of the Canadian Cordillera from Middle Jurassic to Cretaceous (Albian to Cenomanian). Closure of the Jura-Cretaceous basins was and 're-accretion' of the Insular 
terranes was the driving mechanism for the northward escape of the Intermontane terranes during dominantly orthogonal dextral transpression. 


\begin{tabular}{|l|c|c|c|c|c|c|c|}
\hline \multicolumn{7}{|c|}{ Table 1. Geochronology Sample Location and Summary of Ages } \\
\hline \hline \multicolumn{1}{|c|}{ Area } & Sample & $\begin{array}{c}\text { Map } \\
\text { No. }\end{array}$ & Easting & Northing & UTM Zone & Mineral & Age (Ma) \\
\hline Hoge Creek & $09-R C-151-1$ & n/a & 577447 & 6795148 & 7 & Zircon & $15.45 \pm 0.01$ \\
\hline Klutlan Glacier & 08-RC-060-1b & 1 & 517200 & 6808953 & 7 & Muscovite & $267.5 \pm 6.4$ \\
\hline Klutlan Glacier & 08-RC-071-1 & 2 & 517701 & 6808546 & 7 & Muscovite & $256.8 \pm 6.6$ \\
\hline Dollis Creek & 08-RC-024-1A & 3 & 382803 & 6653051 & 8 & Muscovite & $82.8 \pm 2.7$ \\
\hline Dollis Creek & 08-RC-024-1B & 4 & 382803 & 6653051 & 8 & Muscovite & $104.6 \pm 2.2$ \\
\hline Dollis Creek & 08-RC-028-1 & 5 & 381293 & 6654588 & 8 & Muscovite & $90.1 \pm 4.3$ \\
\hline Jessie Creek & 09-RC-063-C1 & 6 & 639353 & 6758477 & 7 & Muscovite & $104.1 \pm 3.7$ \\
\hline
\end{tabular}


$\mathrm{U}-\mathrm{Pb}$ isotopic data.

\begin{tabular}{|c|c|c|c|c|c|c|c|c|c|c|c|c|c|c|c|c|c|c|c|c|}
\hline \multirow[b]{2}{*}{$\begin{array}{c}\text { Sampl } \\
\text { e } \\
\text { (a) }\end{array}$} & \multirow[b]{2}{*}{$\begin{array}{l}\frac{\mathrm{Th}}{\mathrm{U}} \\
\text { (b) }\end{array}$} & \multirow[b]{2}{*}{$\begin{array}{c}{ }^{206} \mathrm{~Pb}^{*} \\
\mathrm{x} 10^{-13} \mathrm{~mol} \\
\text { (c) }\end{array}$} & \multirow[b]{2}{*}{$\begin{array}{c}\mathrm{mol} \\
\% \\
\\
{ }^{206} \mathrm{~Pb}^{*} \\
\text { (c) } \\
\end{array}$} & \multirow[b]{2}{*}{$\begin{array}{l}\underline{\mathrm{Pb}^{*}} \\
\mathrm{~Pb}_{\mathrm{c}} \\
(\mathrm{c})\end{array}$} & \multirow[b]{2}{*}{$\begin{array}{c}\mathrm{Pb}_{\mathrm{c}} \\
(\mathrm{pg} \\
) \\
(\mathrm{c}) \\
\end{array}$} & \multirow[b]{2}{*}{$\frac{{ }^{206} \mathrm{~Pb}}{{ }^{204} \mathrm{~Pb}}$} & \multicolumn{8}{|c|}{ Radiogenic lsotope Ratios } & \multicolumn{6}{|c|}{ Isotopic Ages } \\
\hline & & & & & & & $\begin{array}{l}{ }^{\frac{208}{206} \mathrm{~Pb}} \\
(\mathrm{e}) \\
\end{array}$ & 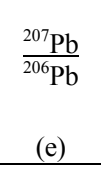 & $\begin{array}{l}\% \\
\text { err } \\
\text { (f) }\end{array}$ & $\begin{array}{l}{ }^{\frac{207}{} \mathrm{~Pb}} \\
\text { (e) } \\
\end{array}$ & $\begin{array}{l}\% \\
\text { err } \\
\text { (f) }\end{array}$ & $\begin{array}{l}{ }^{206} \mathrm{~Pb} \\
\text { (e) }\end{array}$ & $\begin{array}{l}\% \\
\text { err } \\
\text { (f) }\end{array}$ & $\begin{array}{l}\text { corr. } \\
\text { coef. }\end{array}$ & 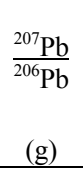 & (f) & $\begin{array}{l}\frac{{ }^{207} \mathrm{~Pb}}{{ }^{235} \mathrm{U}} \\
(\mathrm{g})\end{array}$ & (f) & $\begin{array}{l}{ }^{\frac{206}{{ }^{238} \mathrm{~Pb}}} \\
(\mathrm{~g}) \\
\end{array}$ & (f) \\
\hline \multicolumn{21}{|c|}{ 09RC151 } \\
\hline $\mathrm{z1}$ & $\begin{array}{c}0.43 \\
1 \\
0.46\end{array}$ & 0.1065 & $\begin{array}{c}96.31 \\
\% \\
91.76\end{array}$ & 7.7 & 0.34 & 489 & 0.139 & $\begin{array}{c}0.04697 \\
0 \\
0.04685\end{array}$ & 1.327 & $\begin{array}{c}0.01556 \\
6 \\
0.01555\end{array}$ & 1.414 & $\begin{array}{c}0.002403 \\
6 \\
0.002407\end{array}$ & 0.162 & 0.577 & 47.69 & $\begin{array}{c}31.6 \\
2 \\
53.2\end{array}$ & 15.68 & $\begin{array}{c}0.2 \\
2 \\
0.3\end{array}$ & 15.476 & $\begin{array}{c}0.02 \\
5 \\
0.03\end{array}$ \\
\hline $\mathrm{z} 2$ & $\begin{array}{c}3 \\
0.45\end{array}$ & 0.1439 & $\begin{array}{c}\% \\
93.40\end{array}$ & 3.3 & 1.07 & 219 & 0.150 & $\begin{array}{c}1 \\
0.04721\end{array}$ & 2.231 & $\begin{array}{c}1 \\
0.01560\end{array}$ & 2.393 & $\begin{array}{c}4 \\
0.002396\end{array}$ & 0.222 & 0.750 & 41.63 & $\begin{array}{c}0 \\
49.7\end{array}$ & 15.67 & $\begin{array}{c}7 \\
0.3\end{array}$ & 15.500 & $\begin{array}{c}4 \\
0.03\end{array}$ \\
\hline $\mathrm{z3}$ & $\begin{array}{c}2 \\
0.37\end{array}$ & 0.0917 & $\begin{array}{c}\% \\
94.73\end{array}$ & 4.2 & 0.54 & 273 & 0.146 & $\begin{array}{c}7 \\
0.04633\end{array}$ & 2.093 & $\begin{array}{c}3 \\
0.01534\end{array}$ & 2.234 & $\begin{array}{c}6 \\
0.002402\end{array}$ & 0.195 & 0.741 & 60.22 & $\begin{array}{c}6 \\
36.4\end{array}$ & 15.72 & $\begin{array}{c}5 \\
0.2\end{array}$ & 15.431 & $\begin{array}{c}0 \\
0.02\end{array}$ \\
\hline $\mathrm{z} 4$ & $\begin{array}{c}1 \\
0.36\end{array}$ & 0.1100 & $\begin{array}{c}\% \\
91.96\end{array}$ & 5.2 & 0.51 & 342 & 0.120 & $\begin{array}{c}0 \\
0.04686\end{array}$ & 1.521 & $\begin{array}{c}6 \\
0.01556\end{array}$ & 1.634 & $\begin{array}{c}4 \\
0.002407\end{array}$ & 0.161 & 0.727 & 14.81 & $\begin{array}{c}7 \\
46.8\end{array}$ & 15.46 & $\begin{array}{c}5 \\
0.3\end{array}$ & 15.468 & $\begin{array}{c}5 \\
0.03\end{array}$ \\
\hline $\mathrm{z} 5$ & $\begin{array}{c}1 \\
0.35\end{array}$ & 0.1463 & $\begin{array}{c}\% \\
93.06\end{array}$ & 3.3 & 1.06 & 224 & 0.117 & $\begin{array}{c}8 \\
0.04651\end{array}$ & 1.966 & $\begin{array}{c}0 \\
0.01540\end{array}$ & 2.123 & $\begin{array}{c}9 \\
0.002402\end{array}$ & 0.201 & 0.797 & 42.52 & $\begin{array}{c}9 \\
44.8\end{array}$ & 15.68 & $\begin{array}{c}3 \\
0.3\end{array}$ & 15.504 & $\begin{array}{c}1 \\
0.02\end{array}$ \\
\hline z6 & 1 & 0.1308 & $\%$ & 3.9 & 0.81 & 260 & 0.113 & 3 & 1.875 & 8 & 2.015 & 6 & 0.187 & 0.765 & 24.27 & 6 & 15.53 & 1 & 15.469 & 9 \\
\hline
\end{tabular}

(a) z1, z2, etc. are labels for analyses composed of single zircon grains that were annealed and chemically abraded (Mattinson, 2005). Fraction labels in bold denote analyses used in the weighted mean calculation.

(b) Model Th/U ratio calculated from radiogenic $208 \mathrm{~Pb} / 206 \mathrm{~Pb}$ ratio and $207 \mathrm{~Pb} / 235 \mathrm{U}$ date.

(c) $\mathrm{Pb} *$ and $\mathrm{Pbc}$ are radiogenic and common $\mathrm{Pb}$, respectively. mol $\%{ }^{206} \mathrm{~Pb} *$ is with respect to radiogenic and blank $\mathrm{Pb}$.

(d) Measured ratio corrected for spike and fractionation only. Fractionation correction is $0.15 \pm 0.03$ ( 1 sigma) \%/amu (atomic mass unit) for single-collector Daly analyses, based on analysis of EARTHTIME 202Pb-205Pb tracer solution.

(e) Corrected for fractionation, spike, common $\mathrm{Pb}$, and initial disequilibrium in $230 \mathrm{Th} / 238 \mathrm{U}$. Common $\mathrm{Pb}$ in analyses was assigned to laboratory blank with a composition of $206 \mathrm{~Pb} / 204 \mathrm{~Pb}=18.04 \pm 0.61 \% ; 207 \mathrm{~Pb} / 204 \mathrm{~Pb}=15.54 \pm 0.52 \% ; 208 \mathrm{~Pb} / 204 \mathrm{~Pb}=37.69 \pm 0.63 \%$ ( 1 sigma).

$206 \mathrm{~Pb} / 238 \mathrm{U}$ and $207 \mathrm{~Pb} / 206 \mathrm{~Pb}$ ratios corrected for initial disequilibrium in $230 \mathrm{Th} / 238 \mathrm{U}$ using $\mathrm{Th} / \mathrm{U}$ [magma] $=3.0 \pm 0.3$ (1 sigma).

(f) Errors are 2 sigma, propagated using algorithms of Schmitz and Schoene (2007) and Crowley et al. (2007).

(g) Calculations based on the decay constants of Jaffey et al. (1971). $206 \mathrm{~Pb} / 238 \mathrm{U}$ and $207 \mathrm{~Pb} / 206 \mathrm{~Pb}$ dates corrected for initial disequilibrium in $230 \mathrm{Th} / 238 \mathrm{U}$ using $\mathrm{Th} / \mathrm{U}[\mathrm{magma}]=3.0 \pm 0.3(1 \mathrm{sigma})$ 


\begin{tabular}{|c|c|c|c|c|c|c|c|c|}
\hline \multicolumn{9}{|c|}{ 08RC024-1b Muscovite } \\
\hline \multirow{2}{*}{$\begin{array}{l}\text { Laser } \\
\text { Power(\%) }\end{array}$} & \multicolumn{8}{|l|}{ Isotope Ratios } \\
\hline & $40 \mathrm{Ar} / 39 \mathrm{Ar}$ & $2 \sigma$ & $36 A r / 39 A r$ & $2 \sigma$ & $39 \mathrm{Ar} / 40 \mathrm{Ar}$ & $2 \sigma$ & $36 \mathrm{Ar} / 40 \mathrm{Ar}$ & $2 \sigma$ \\
\hline 2.00 & 181.44 & 21.27 & 0.57992 & 0.16286 & 0.00550 & 0.00065 & 0.00319 & 0.00083 \\
\hline 2.20 & 89.84 & 6.01 & 0.33121 & 0.02327 & 0.01113 & 0.00074 & 0.00368 & 0.00035 \\
\hline 2.40 & 91.87 & 3.81 & 0.27038 & 0.01159 & 0.01088 & 0.00045 & 0.00294 & 0.00013 \\
\hline 2.60 & 49.33 & 1.35 & 0.14003 & 0.00976 & 0.02026 & 0.00055 & 0.00283 & 0.00021 \\
\hline 2.90 & 41.70 & 1.72 & 0.11821 & 0.00516 & 0.02386 & 0.00099 & 0.00279 & 0.00016 \\
\hline 3.20 & 26.70 & 1.38 & 0.05895 & 0.00548 & 0.03729 & 0.00193 & 0.00214 & 0.00023 \\
\hline 3.50 & 19.88 & 0.25 & 0.03199 & 0.00293 & 0.05037 & 0.00063 & 0.00161 & 0.00015 \\
\hline 3.80 & 20.59 & 0.54 & 0.03757 & 0.00122 & 0.04863 & 0.00129 & 0.00183 & 0.00007 \\
\hline 4.00 & 12.66 & 0.27 & 0.00296 & 0.00081 & 0.07918 & 0.00170 & 0.00023 & 0.00006 \\
\hline 4.30 & 12.89 & 0.21 & 0.00221 & 0.00156 & 0.07777 & 0.00125 & 0.00017 & 0.00012 \\
\hline 4.60 & 12.90 & 0.20 & 0.00229 & 0.00184 & 0.07768 & 0.00119 & 0.00018 & 0.00014 \\
\hline 5.00 & 12.23 & 0.28 & 0.00179 & 0.00115 & 0.08198 & 0.00185 & 0.00015 & 0.00009 \\
\hline 5.40 & 12.68 & 0.15 & 0.00323 & 0.00178 & 0.07902 & 0.00095 & 0.00025 & 0.00014 \\
\hline 5.80 & 12.87 & 0.29 & 0.00240 & 0.00262 & 0.07787 & 0.00177 & 0.00018 & 0.00020 \\
\hline 6.20 & 13.71 & 0.17 & 0.00865 & 0.00150 & 0.07307 & 0.00088 & 0.00063 & 0.00011 \\
\hline \multicolumn{3}{|c|}{$J=0.00489900 \pm 0.00000735$} & \multicolumn{3}{|c|}{ Volume $39 \mathrm{ArK}=$} & 0.259 & \multicolumn{2}{|l|}{$x \mathrm{E}-13 \mathrm{~cm} 3 \mathrm{NPT}$} \\
\hline \multicolumn{2}{|c|}{ Integrated Date $=$} & \multicolumn{2}{|c|}{$100.04 \pm 1.45$} & \multicolumn{2}{|l|}{$\mathrm{Ma}$} & & & \\
\hline \multicolumn{3}{|c|}{ Plateau age $=84.9 \pm 4.3 \mathrm{Ma}$} & \multicolumn{3}{|c|}{ ( $2 \mathrm{~s}$, including J-error of .2\%) } & \multicolumn{3}{|c|}{ MSWD $=1.6$, probability $=0.21$} \\
\hline \multicolumn{9}{|c|}{ Inverse isochron (correlation age) results, plateau steps: Model 1 Solution ( $\pm 95 \%$-conf.) on 7 points } \\
\hline \multicolumn{3}{|c|}{ Age $=85 \pm 12 \mathrm{Ma}$} & \multicolumn{2}{|c|}{ Initial $40 \mathrm{Ar} / 36 \mathrm{Ar}=293 \pm 23$} & & $\mathrm{MSWD}=2.0$ & \multicolumn{2}{|c|}{ Probability $=0$. } \\
\hline \multicolumn{9}{|c|}{ Inverse isochron (correlation age) results, plateau steps: Model 1 Solution ( $\pm 95 \%$-conf.) on 7 points } \\
\hline \multicolumn{3}{|c|}{$\mathrm{Age}=104.2 \pm 4.0 \mathrm{Ma}$} & \multicolumn{2}{|c|}{ Initial $40 \mathrm{Ar} / 36 \mathrm{Ar}=195 \pm 110$} & & MSWD = 1.8 & \multicolumn{2}{|c|}{ Probability $=0$. } \\
\hline
\end{tabular}

Analysis by Janet Gabites

Pacific Centre for Isotopic and Geochemical Research,

Dept Earth and Ocean Sciences,

The University of British Columbia,

Vancouver, BC., Canada 


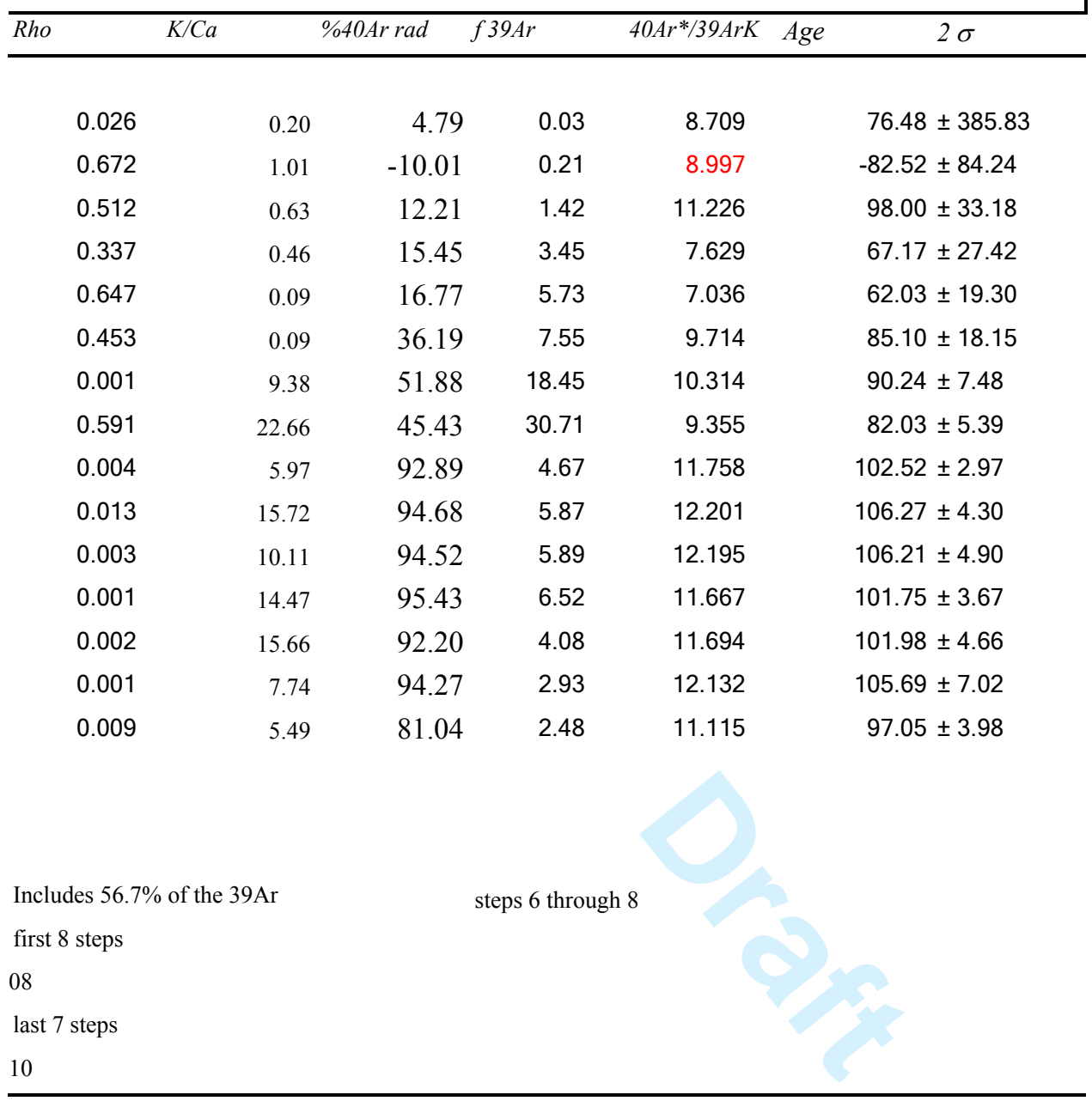




\begin{tabular}{|c|c|c|c|c|c|c|c|c|}
\hline \multicolumn{9}{|c|}{ 08RC024-1A Muscovite } \\
\hline \multirow{2}{*}{\begin{tabular}{|l} 
Laser \\
Power(\%)
\end{tabular}} & \multicolumn{8}{|l|}{ Isotope Ratios } \\
\hline & $40 \mathrm{Ar} / 39 \mathrm{Ar}$ & $2 \sigma$ & $36 \mathrm{Ar} / 39 \mathrm{Ar}$ & $2 \sigma$ & $39 \mathrm{Ar} / 40 \mathrm{Ar}$ & $2 \sigma$ & $36 \mathrm{Ar} / 40 \mathrm{Ar}$ & $2 \sigma$ \\
\hline 2.00 & 63.51 & 7.69 & 0.17021 & 0.04091 & 0.01573 & 0.00191 & 0.00268 & 0.00062 \\
\hline 2.20 & 29.56 & 0.98 & 0.07148 & 0.00533 & 0.03383 & 0.00113 & 0.00242 & 0.00018 \\
\hline 2.40 & 25.05 & 0.86 & 0.06084 & 0.00534 & 0.03989 & 0.00137 & 0.00242 & 0.00023 \\
\hline 2.70 & 16.57 & 0.51 & 0.02826 & 0.00169 & 0.06004 & 0.00185 & 0.00159 & 0.00011 \\
\hline 3.00 & 17.04 & 0.37 & 0.02871 & 0.00152 & 0.05811 & 0.00127 & 0.00147 & 0.00009 \\
\hline 3.30 & 15.88 & 0.55 & 0.02481 & 0.00186 & 0.06293 & 0.00216 & 0.00154 & 0.00013 \\
\hline 3.60 & 16.22 & 0.62 & 0.02318 & 0.00224 & 0.06167 & 0.00235 & 0.00143 & 0.00015 \\
\hline 3.90 & 17.06 & 0.48 & 0.02739 & 0.00184 & 0.05862 & 0.00165 & 0.00160 & 0.00012 \\
\hline 4.20 & 17.37 & 0.55 & 0.02826 & 0.00138 & 0.05757 & 0.00182 & 0.00163 & 0.00009 \\
\hline 4.50 & 15.24 & 0.25 & 0.01852 & 0.00135 & 0.06562 & 0.00107 & 0.00121 & 0.00009 \\
\hline 4.80 & 19.41 & 0.67 & 0.03962 & 0.00226 & 0.05152 & 0.00178 & 0.00204 & 0.00013 \\
\hline 5.10 & 16.38 & 0.32 & 0.04262 & 0.00608 & 0.06108 & 0.00121 & 0.00260 & 0.00037 \\
\hline 5.50 & 16.85 & 0.28 & 0.02708 & 0.00437 & 0.05937 & 0.00097 & 0.00160 & 0.00026 \\
\hline 6.00 & 23.01 & 1.30 & 0.05010 & 0.00461 & 0.04346 & 0.00246 & 0.00218 & 0.00023 \\
\hline \multicolumn{3}{|c|}{$\mathrm{J}=0.00488400 \pm 0.00000733$} & \multicolumn{3}{|c|}{ Volume 39ArK = } & 0.263 & \multicolumn{2}{|l|}{$x \mathrm{E}-13 \mathrm{~cm} 3 \mathrm{NPT}$} \\
\hline \multicolumn{2}{|c|}{ Integrated Date $=$} & \multicolumn{2}{|c|}{$78.58 \pm 1.92$} & \multicolumn{2}{|c|}{$\mathrm{Ma}$} & & \\
\hline \multicolumn{3}{|c|}{ Plateau age $=79.3 \pm 2.5 \mathrm{Ma}$} & \multicolumn{2}{|c|}{ ( $2 \mathrm{~s}$, including J-error of .2\%) } & \multicolumn{2}{|c|}{ MSWD $=1.5$, probability $=0.20$} & & \\
\hline \multicolumn{7}{|c|}{ Inverse isochron (correlation age) results, plateau steps: Model 1 Solution ( $\pm 95 \%$-conf.) on 9 points } & \multicolumn{2}{|c|}{ Includes $/ 8.3 \%$} \\
\hline \multicolumn{2}{|c|}{ Age $=83 \pm 11 \mathrm{Ma}$} & \multicolumn{3}{|c|}{ Initial $40 \mathrm{Ar} / 36 \mathrm{Ar}=277 \pm 42$} & \multicolumn{2}{|c|}{$\mathrm{MSWD}=1.7$} & \multicolumn{2}{|c|}{ Probability $=0$. } \\
\hline \multicolumn{5}{|c|}{$\begin{array}{l}\text { Analysis by Janet Gabites } \\
\text { Pacific Centre for Isotopic and Geochemical Research, } \\
\text { Dept Earth and Ocean Sciences, } \\
\text { The University of British Columbia, } \\
\text { Vancouver, BC., Canada }\end{array}$} & & & & \\
\hline
\end{tabular}




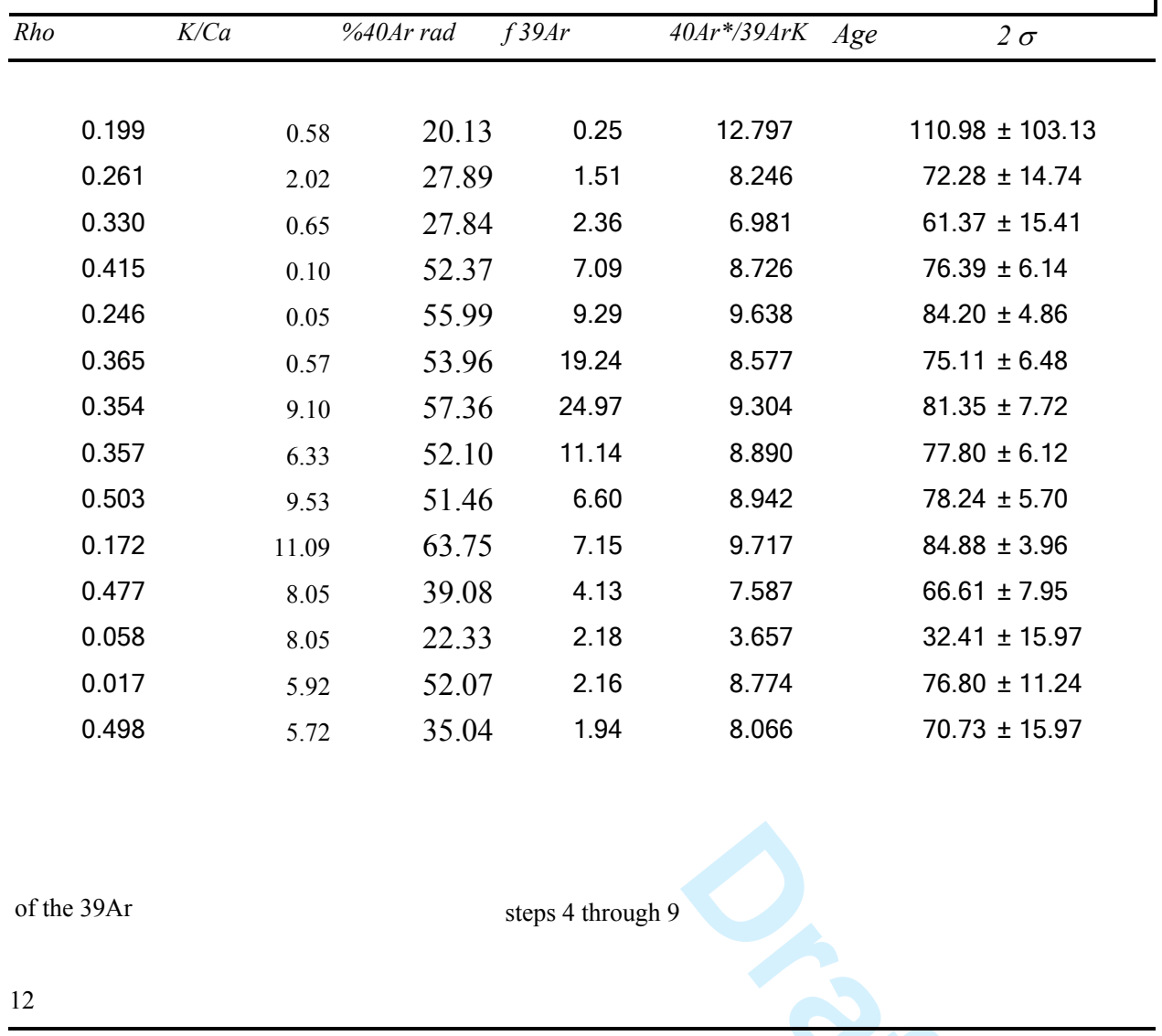




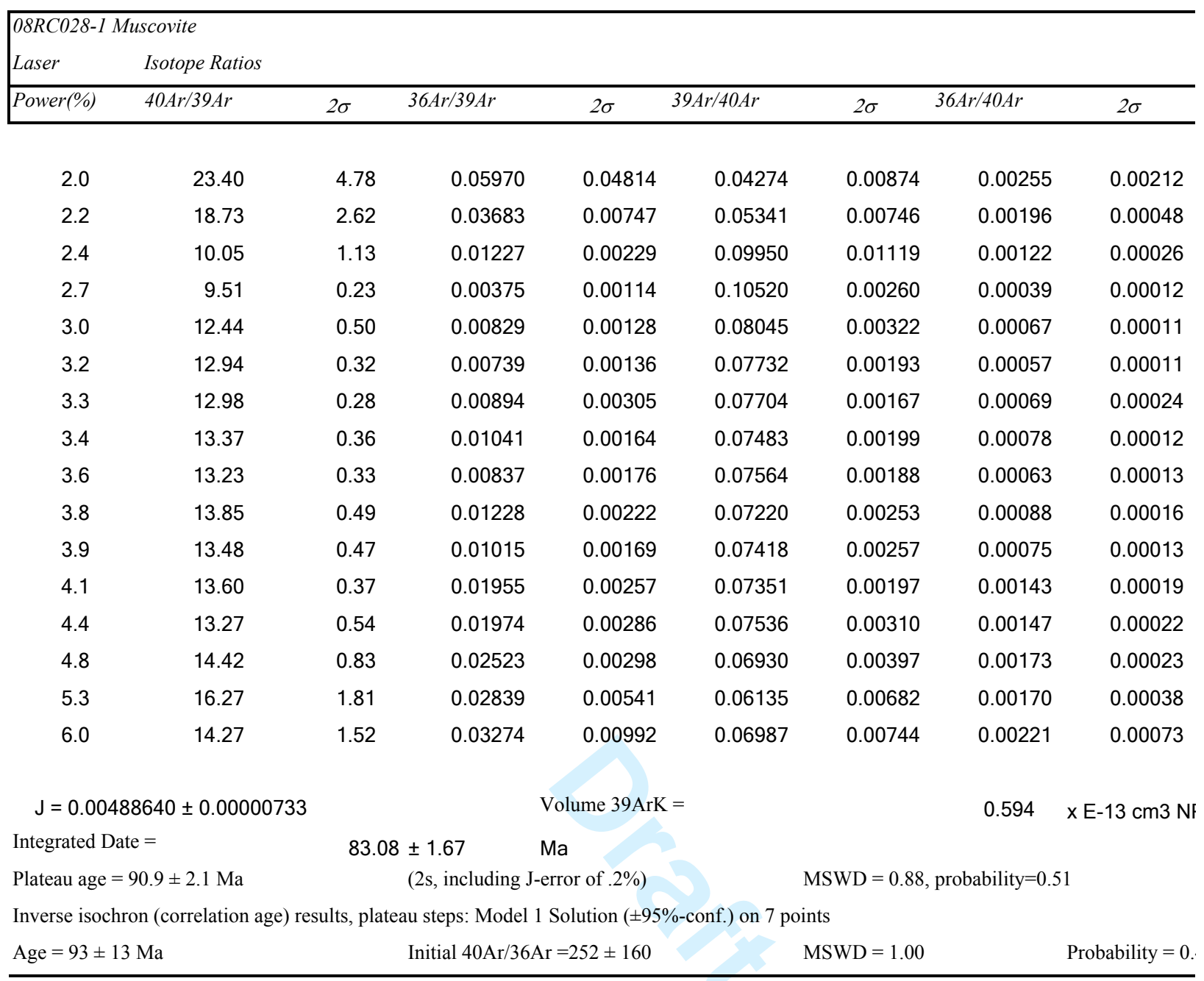

Analysis by Janet Gabites

Pacific Centre for Isotopic and Geochemical Research,

Dept Earth and Ocean Sciences,

The University of British Columbia,

Vancouver, BC., Canada 


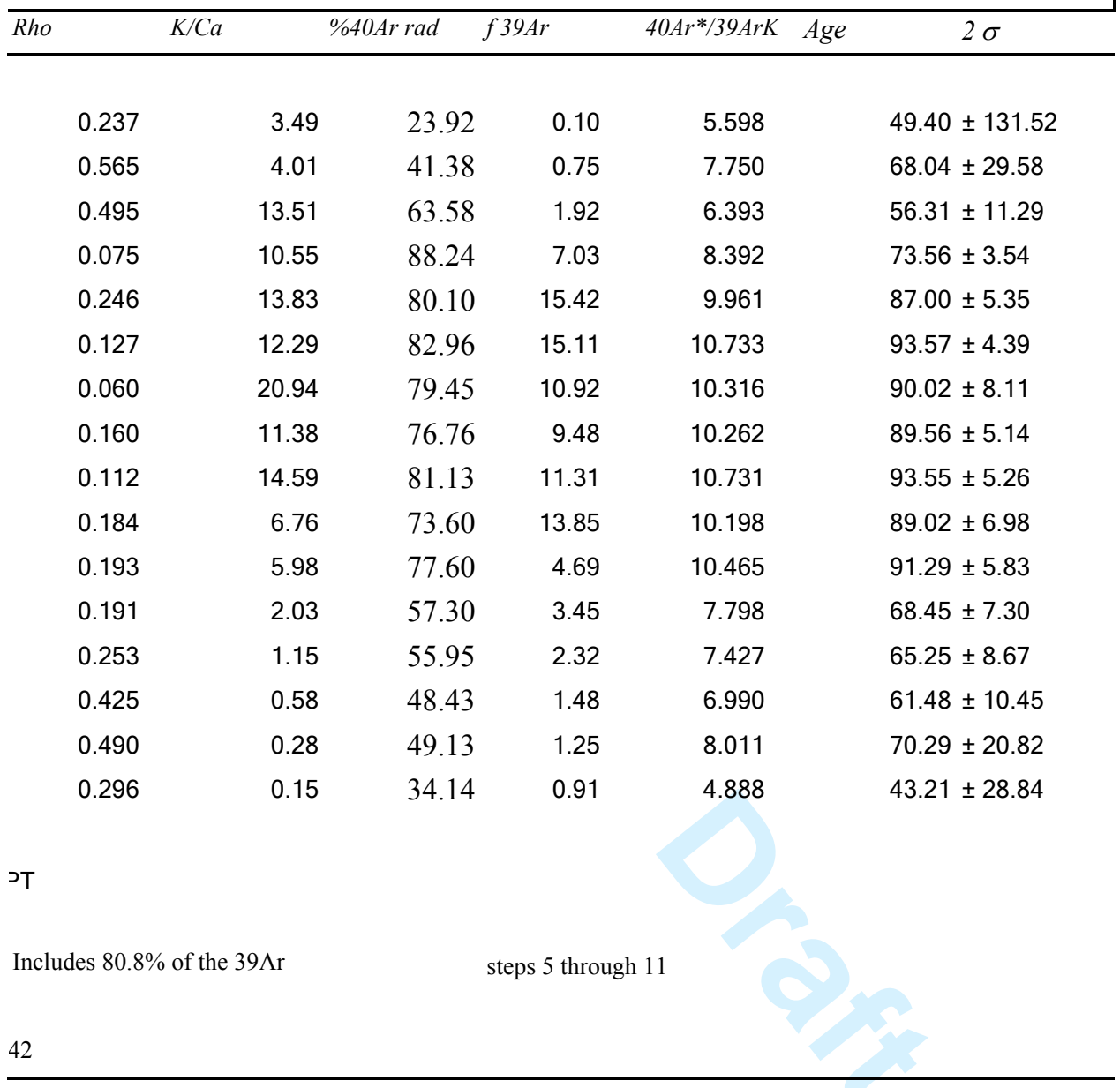




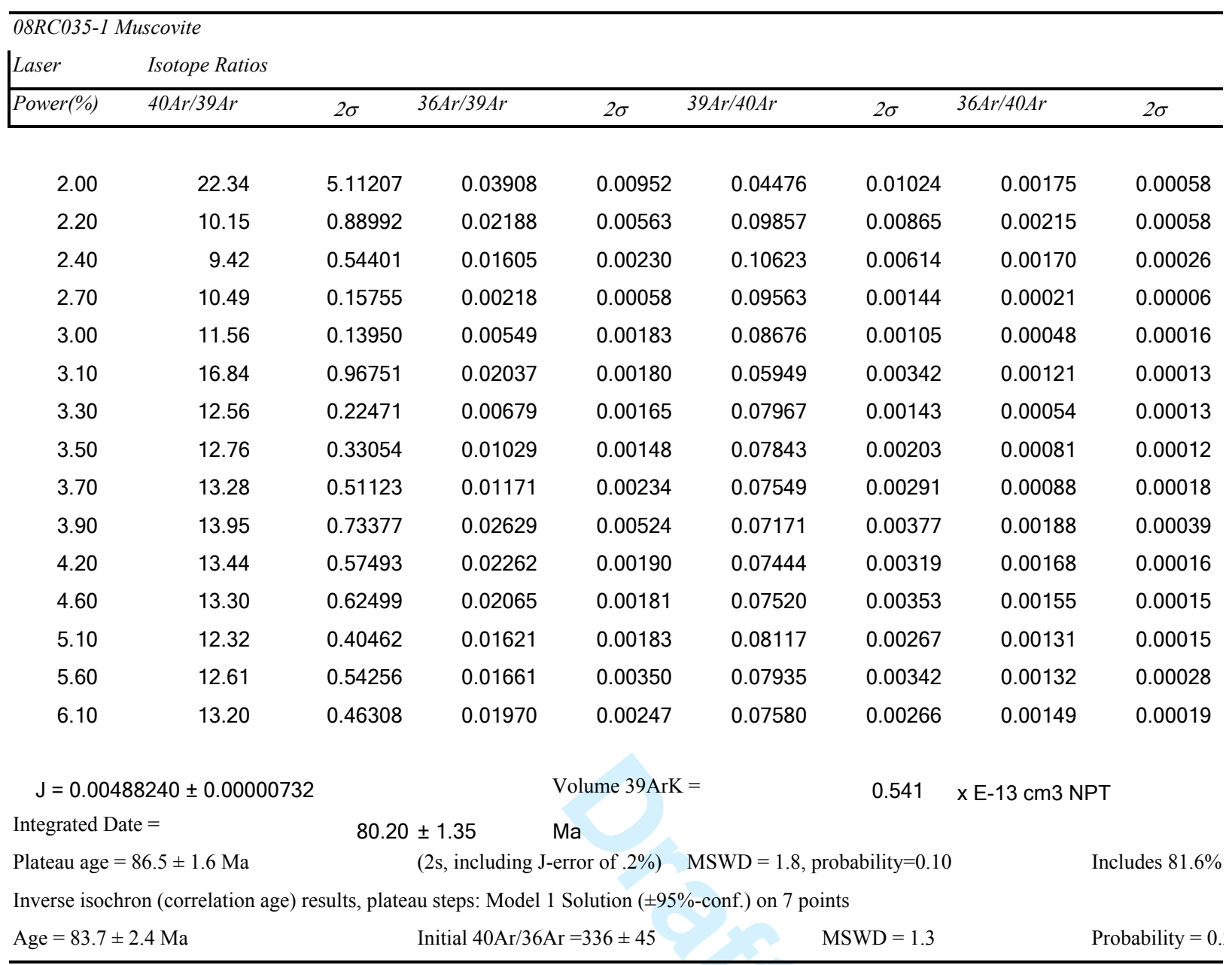

Analysis by Janet Gabites

Pacific Centre for Isotopic and Geochemical Research,

Dept Earth and Ocean Sciences,

The University of British Columbia,

Vancouver, BC., Canada 


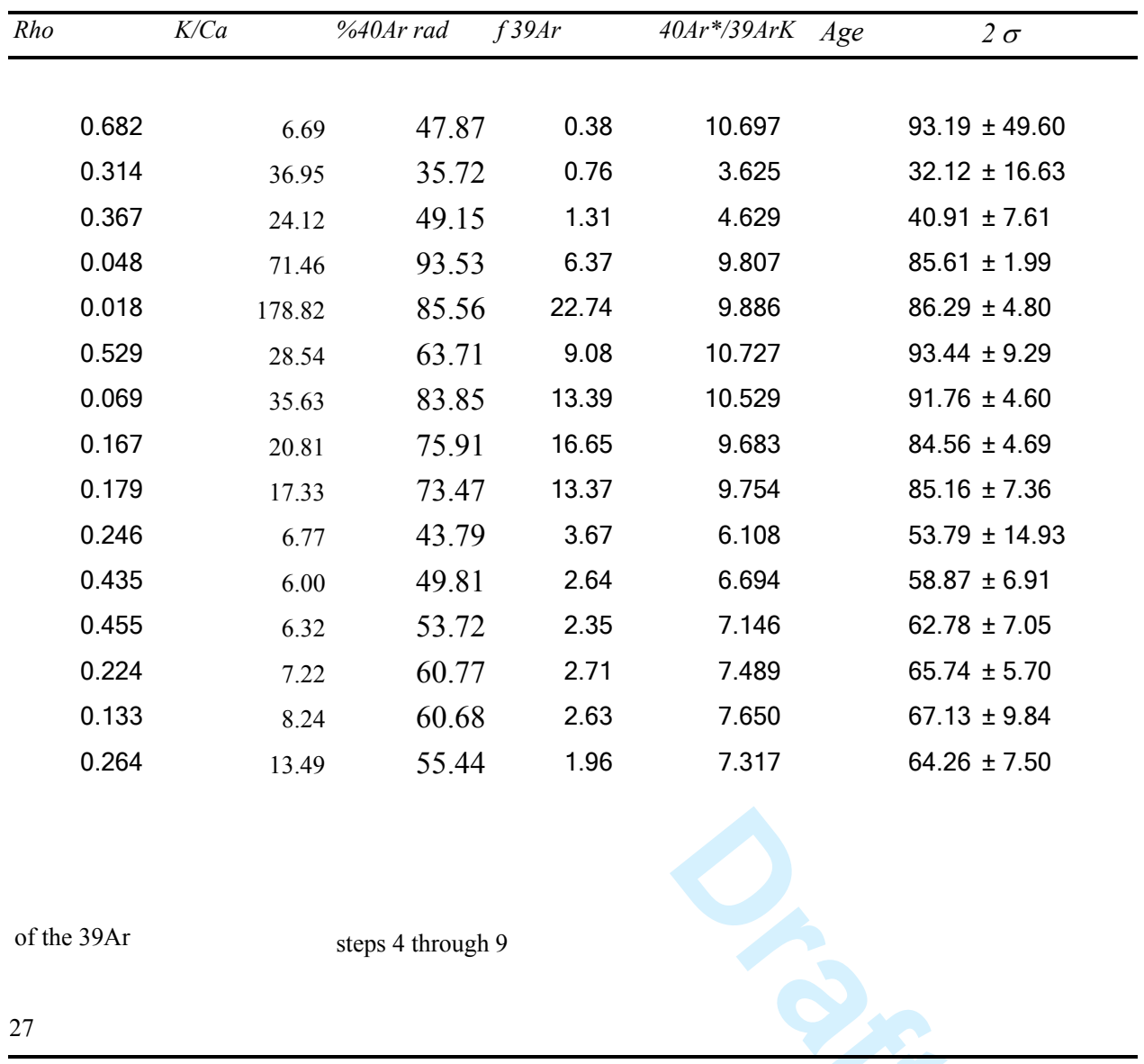




\begin{tabular}{|c|c|c|c|c|c|c|c|c|}
\hline \multicolumn{9}{|c|}{ 08RC57-3 Muscovite } \\
\hline \multirow{2}{*}{\begin{tabular}{|l} 
Laser \\
Power(\%)
\end{tabular}} & \multicolumn{8}{|l|}{ Isotope Ratios } \\
\hline & $40 \mathrm{Ar} / 39 \mathrm{Ar}$ & $2 \sigma$ & $36 \mathrm{Ar} / 39 \mathrm{Ar}$ & $2 \sigma$ & $39 \mathrm{Ar} / 40 \mathrm{Ar}$ & $2 \sigma$ & $36 \mathrm{Ar} / 40 \mathrm{Ar}$ & $2 \sigma$ \\
\hline 2.00 & 33.49 & 1.81 & 0.04639 & 0.07690 & 0.02984 & 0.00161 & 0.00137 & 0.00230 \\
\hline 2.20 & 42.47 & 1.04 & 0.12559 & 0.01094 & 0.02354 & 0.00058 & 0.00295 & 0.00026 \\
\hline 2.40 & 44.97 & 0.94 & 0.06655 & 0.01011 & 0.02223 & 0.00047 & 0.00147 & 0.00022 \\
\hline 2.70 & 35.83 & 4.81 & 0.05604 & 0.00628 & 0.02789 & 0.00374 & 0.00155 & 0.00027 \\
\hline 3.00 & 37.79 & 2.70 & 0.03098 & 0.00488 & 0.02634 & 0.00188 & 0.00078 & 0.00014 \\
\hline 3.30 & 51.18 & 6.86 & 0.07062 & 0.00877 & 0.01939 & 0.00260 & 0.00133 & 0.00025 \\
\hline 3.50 & 53.31 & 2.65 & 0.07945 & 0.00864 & 0.01868 & 0.00093 & 0.00146 & 0.00017 \\
\hline 3.70 & 33.16 & 0.67 & 0.00973 & 0.00286 & 0.03016 & 0.00061 & 0.00029 & 0.00009 \\
\hline 4.00 & 29.24 & 0.56 & 0.00621 & 0.00357 & 0.03420 & 0.00066 & 0.00021 & 0.00012 \\
\hline 4.40 & 22.68 & 0.44 & 0.01015 & 0.00793 & 0.04409 & 0.00085 & 0.00044 & 0.00035 \\
\hline 4.80 & 19.78 & 0.59 & 0.01107 & 0.00733 & 0.05054 & 0.00151 & 0.00054 & 0.00037 \\
\hline 5.30 & 25.22 & 0.75 & 0.01412 & 0.00566 & 0.03964 & 0.00118 & 0.00054 & 0.00022 \\
\hline 5.90 & 24.32 & 0.54 & 0.02257 & 0.00544 & 0.04109 & 0.00091 & 0.00090 & 0.00022 \\
\hline \multicolumn{4}{|c|}{$\mathrm{J}=0.00488640 \pm 0.00000733$} & & \multicolumn{2}{|l|}{ Volume 39ArK = } & 0.096 & $x \mathrm{E}-13 \mathrm{~cm} 3 \mathrm{NF}$ \\
\hline \multicolumn{2}{|c|}{ Integrated Date $=$} & 210.3 & $3 \pm 4.57$ & & & & & \\
\hline \multicolumn{5}{|c|}{ Plateau age $=251.8 \pm 7.5 \mathrm{Ma}$} & \multicolumn{3}{|c|}{ MSWD $=0.18$, probability $=0.91$} & Includes $67.3 \%$ \\
\hline \multicolumn{9}{|c|}{ Inverse isochron (correlation age) results, plateau steps: Model 1 Solution ( $\pm 95 \%$-conf.) on 4 points } \\
\hline \multicolumn{3}{|c|}{ Age $=248.4 \pm 9.8 \mathrm{Ma}$} & \multicolumn{2}{|c|}{ Initial $40 \mathrm{Ar} / 36 \mathrm{Ar}=297 \pm 49$} & \multicolumn{3}{|c|}{ MSWD $=0.26$} & Probability $=0$. \\
\hline
\end{tabular}

Analysis by Janet Gabites

Pacific Centre for Isotopic and Geochemical Research,

Dept Earth and Ocean Sciences,

The University of British Columbia,

Vancouver, BC., Canada 


\begin{tabular}{|c|c|c|c|c|c|c|c|}
\hline Rho & $\mathrm{K} / \mathrm{Ca}$ & & $\% 40 \mathrm{Ar} \mathrm{rad}$ & & $40 \mathrm{Ar} * / 39 \mathrm{ArK}$ & Age & $2 \sigma$ \\
\hline 0.008 & & 0.70 & 58.96 & 0.22 & 19.762 & & $168.74 \pm 187.64$ \\
\hline 0.220 & & 1.64 & 12.02 & 1.55 & 5.108 & & $45.12 \pm 29.44$ \\
\hline 0.019 & & 2.23 & 56.18 & 2.67 & 25.268 & & $213.11 \pm 24.30$ \\
\hline 0.761 & & 0.52 & 53.74 & 8.96 & 19.273 & & $164.75 \pm 42.05$ \\
\hline 0.388 & & 0.11 & 76.83 & 27.21 & 29.165 & & $243.88 \pm 24.04$ \\
\hline 0.716 & & 0.07 & 60.42 & 23.36 & 31.164 & & $259.46 \pm 57.25$ \\
\hline 0.374 & & 0.12 & 56.37 & 10.04 & 30.177 & & $251.78 \pm 28.26$ \\
\hline 0.036 & & 3.27 & 91.28 & 6.68 & 30.274 & & $252.54 \pm 8.31$ \\
\hline 0.001 & & 2.46 & 93.74 & 4.54 & 27.414 & & $230.12 \pm 9.39$ \\
\hline 0.003 & & 1.30 & 86.87 & 3.83 & 19.708 & & $168.30 \pm 19.57$ \\
\hline 0.004 & & 0.95 & 83.84 & 3.23 & 16.592 & & $142.70 \pm 18.56$ \\
\hline 0.053 & & 0.88 & 83.88 & 3.99 & 21.167 & & $180.16 \pm 14.90$ \\
\hline 0.006 & & 0.86 & 73.12 & 3.70 & 17.796 & & $152.63 \pm 13.73$ \\
\hline \multicolumn{8}{|l|}{ गT } \\
\hline \multicolumn{3}{|l|}{ of the 39Ar } & \multicolumn{5}{|l|}{ steps 5 through 8} \\
\hline 77 & & & & & & & \\
\hline
\end{tabular}




\begin{tabular}{|c|c|c|c|c|c|c|c|c|}
\hline \multicolumn{9}{|c|}{ 08RC60-1B Muscovite } \\
\hline \multirow{2}{*}{\begin{tabular}{|l} 
Laser \\
Power(\%)
\end{tabular}} & \multicolumn{8}{|l|}{ Isotope Ratios } \\
\hline & $40 \mathrm{Ar} / 39 \mathrm{Ar}$ & $2 \sigma$ & $36 \mathrm{Ar} / 39 \mathrm{Ar}$ & $2 \sigma$ & $39 \mathrm{Ar} / 40 \mathrm{Ar}$ & $2 \sigma$ & $36 \mathrm{Ar} / 40 \mathrm{Ar}$ & $2 \sigma$ \\
\hline 2.00 & 108.05 & 46.24 & 0.44597 & 0.39341 & 0.00925 & 0.00396 & 0.00413 & 0.00329 \\
\hline 2.20 & 46.16 & 3.72 & 0.09943 & 0.06874 & 0.02167 & 0.00175 & 0.00215 & 0.00148 \\
\hline 2.40 & 44.01 & 2.13 & 0.10387 & 0.04152 & 0.02270 & 0.00110 & 0.00235 & 0.00094 \\
\hline 2.70 & 28.12 & 0.80 & 0.06065 & 0.00877 & 0.03555 & 0.00102 & 0.00215 & 0.00031 \\
\hline 3.00 & 34.76 & 0.67 & 0.05559 & 0.00707 & 0.02870 & 0.00056 & 0.00157 & 0.00020 \\
\hline 3.30 & 39.97 & 0.43 & 0.05948 & 0.00586 & 0.02496 & 0.00027 & 0.00146 & 0.00015 \\
\hline 3.60 & 51.40 & 2.16 & 0.07195 & 0.00342 & 0.01944 & 0.00082 & 0.00140 & 0.00006 \\
\hline 3.90 & 38.72 & 0.48 & 0.02519 & 0.00158 & 0.02583 & 0.00032 & 0.00065 & 0.00004 \\
\hline 4.20 & 39.12 & 0.44 & 0.02925 & 0.00375 & 0.02557 & 0.00029 & 0.00075 & 0.00010 \\
\hline 4.60 & 37.52 & 0.33 & 0.02555 & 0.00478 & 0.02665 & 0.00024 & 0.00068 & 0.00013 \\
\hline 5.10 & 42.74 & 1.40 & 0.04199 & 0.00374 & 0.02340 & 0.00077 & 0.00098 & 0.00009 \\
\hline 5.70 & 38.06 & 0.54 & 0.02758 & 0.00385 & 0.02627 & 0.00037 & 0.00072 & 0.00010 \\
\hline \multicolumn{3}{|c|}{$\mathrm{J}=0.00488480 \pm 0.00000733$} & \multicolumn{3}{|c|}{ Volume $39 \mathrm{ArK}=$} & 0.074 & \multicolumn{2}{|l|}{$x \mathrm{E}-13 \mathrm{~cm} 3 \mathrm{NPT}$} \\
\hline \multicolumn{2}{|c|}{ Integrated Date $=$} & \multicolumn{2}{|c|}{$245.35 \pm 3.24$} & \multicolumn{2}{|c|}{$\mathrm{Ma}$} & & & \\
\hline \multicolumn{3}{|c|}{ Plateau age $=256.5 \pm 3.7 \mathrm{Ma}$} & \multicolumn{2}{|c|}{ (2s, including J-error of .2\%) } & \multicolumn{2}{|c|}{ MSWD $=1.2$, probability $=0.30$} & \multicolumn{2}{|c|}{ Includes $76.5 \%$} \\
\hline \multicolumn{9}{|c|}{ Inverse isochron (correlation age) results, plateau steps: Model 1 Solution ( $\pm 95 \%$-conf.) on 5 points } \\
\hline \multicolumn{3}{|c|}{ Age $=255.5 \pm 9.3 \mathrm{Ma}$} & \multicolumn{2}{|c|}{ Initial $40 \mathrm{Ar} / 36 \mathrm{Ar}=283 \pm 39$} & \multicolumn{2}{|c|}{ MSWD = 1.6} & \multicolumn{2}{|c|}{ Probability $=0$. } \\
\hline
\end{tabular}

Analysis by Janet Gabites

Pacific Centre for Isotopic and Geochemical Research,

Dept Earth and Ocean Sciences,

The University of British Columbia,

Vancouver, BC., Canada 


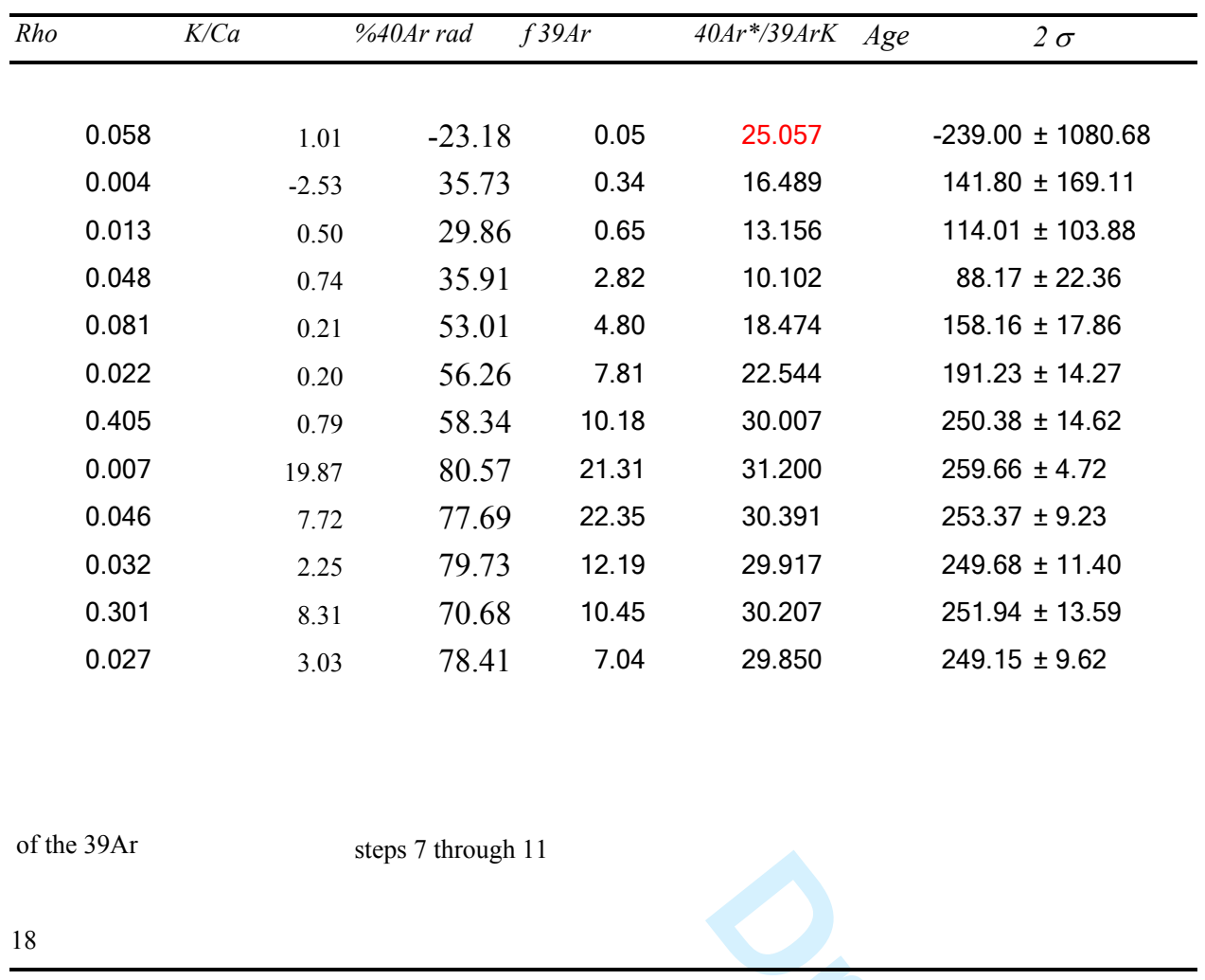




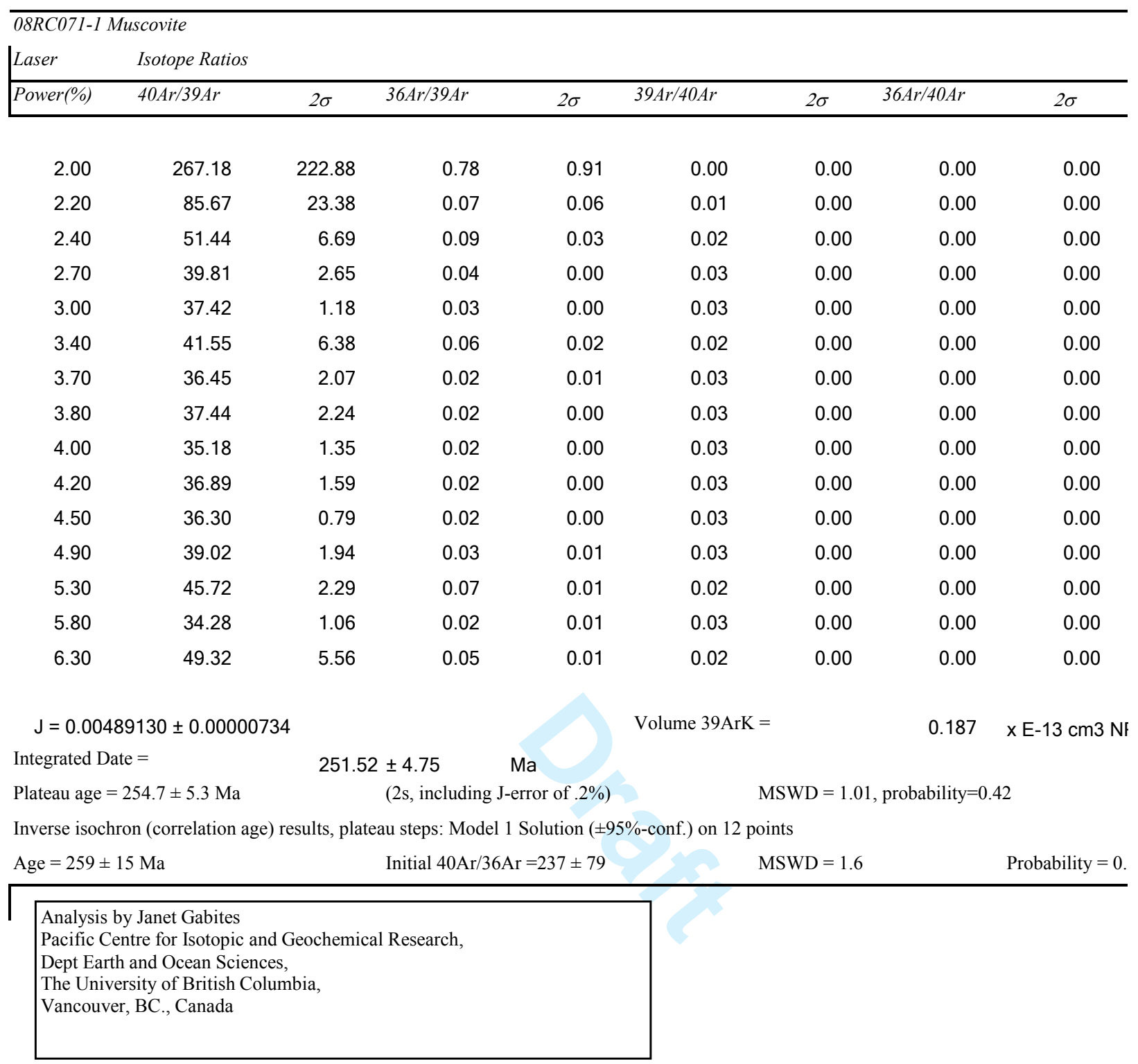




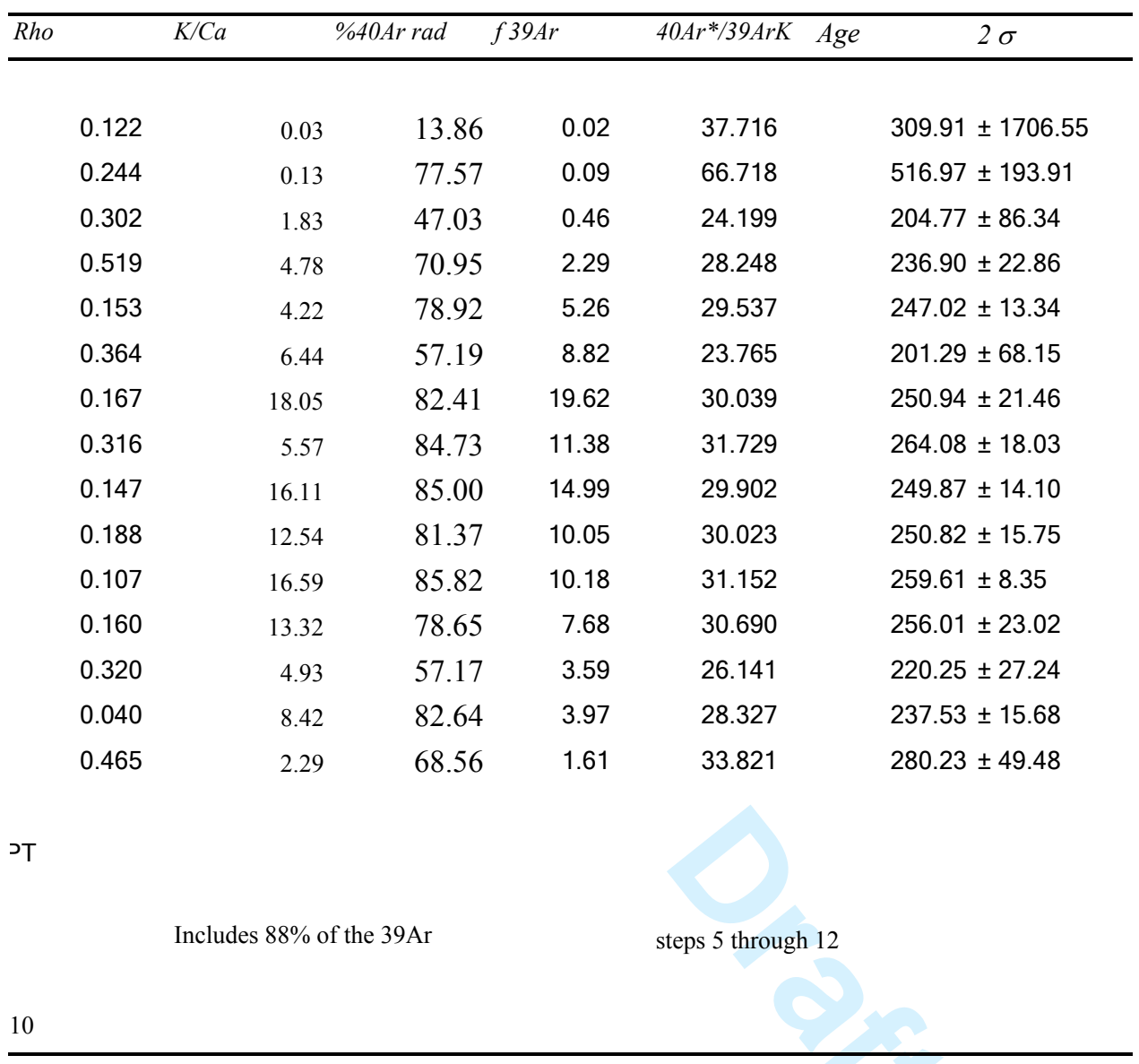




\section{APPENDICES}

\section{Appendix I}

\section{Geochronological Methods}

\section{U-Pb TIMS - Boise State University - Isotope Geology Laboratory}

\section{CA-TIMS Methods}

$\mathrm{U}-\mathrm{Pb}$ dates were obtained by the chemical abrasion isotope dilution thermal ionization mass spectrometry (CA-TIMS) method from analyses composed of single zircon grains (Table I), modified after Mattinson (2005). Zircon was separated from rocks using standard techniques and mounted in epoxy and polished until the centers of the grains were exposed.

Zircon was placed in a muffle furnace at $900^{\circ} \mathrm{C}$ for 60 hours in quartz beakers. Single grains were then transferred to $3 \mathrm{ml}$ Teflon PFA beakers and loaded into $300 \mu \mathrm{l}$ Teflon PFA microcapsules. Fifteen microcapsules were placed in a large-capacity Parr vessel and the grains partially dissolved in $120 \mu$ of $29 \mathrm{M} \mathrm{HF}$ for 12 hours at $180^{\circ} \mathrm{C}$. The contents of the microcapsules were returned to $3 \mathrm{ml}$ Teflon PFA beakers, $\mathrm{HF}$ removed, and the residual grains immersed in $3.5 \mathrm{M} \mathrm{HNO}_{3}$, ultrasonically cleaned for an hour, and fluxed on a hotplate at $80^{\circ} \mathrm{C}$ for an hour. The $\mathrm{HNO}_{3}$ was removed and grains were rinsed twice in ultrapure $\mathrm{H}_{2} \mathrm{O}$ before being reloaded into the $300 \mu$ I Teflon PFA microcapsules (rinsed and fluxed in 6 $\mathrm{M} \mathrm{HCl}$ during sonication and washing of the grains) and spiked with the Boise State University mixed ${ }^{233} \mathrm{U}^{235} \mathrm{U}-{ }^{205} \mathrm{~Pb}$ tracer solution. Zircon was dissolved in Parr vessels in $120 \mu \mathrm{l}$ of $29 \mathrm{M} \mathrm{HF}$ with a trace of 3.5 $\mathrm{M} \mathrm{HNO}_{3}$ at $220^{\circ} \mathrm{C}$ for 48 hours, dried to fluorides, and re-dissolved in $6 \mathrm{M} \mathrm{HCl}$ at $180^{\circ} \mathrm{C}$ overnight. $\mathrm{U}$ and $\mathrm{Pb}$ were separated from the zircon matrix using an $\mathrm{HCl}$-based anion-exchange chromatographic procedure (Krogh, 1973), eluted together and dried with $2 \mu$ of $0.05 \mathrm{~N} \mathrm{H}_{3} \mathrm{PO}_{4}$. 
$\mathrm{Pb}$ and $\mathrm{U}$ were loaded on a single outgassed Re filament in $5 \mu \mathrm{l}$ of a silica-gel/phosphoric acid mixture (Gerstenberger and Haase, 1997), and U and Pb isotopic measurements made on a GV Isoprobe-T multicollector thermal ionization mass spectrometer equipped with an ion-counting Daly detector. $\mathrm{Pb}$ isotopes were measured by peak-jumping all isotopes on the Daly detector for 100 to 160 cycles, and corrected for $0.15 \pm 0.03 \% /$ a.m.u. (1 sigma error) mass fractionation. Transitory isobaric interferences due to high-molecular weight organics, particularly on ${ }^{204} \mathrm{~Pb}$ and ${ }^{207} \mathrm{~Pb}$, disappeared within approximately 60 cycles, while ionization efficiency averaged $10^{4} \mathrm{cps} / \mathrm{pg}$ of each $\mathrm{Pb}$ isotope. Linearity (to $\geq 1.4 \times 10^{6} \mathrm{cps}$ ) and the associated deadtime correction of the Daly detector were monitored by repeated analyses of NBS982, and have been constant since installation. Uranium was analyzed as $\mathrm{UO}_{2}{ }^{+}$ ions in static Faraday mode on $10^{11}$ ohm resistors for 300 cycles, and corrected for isobaric interference of ${ }^{233} \mathrm{U}^{18} \mathrm{O}^{16} \mathrm{O}$ on ${ }^{235} \mathrm{U}^{16} \mathrm{O}^{16} \mathrm{O}$ with an ${ }^{18} \mathrm{O} /{ }^{16} \mathrm{O}$ of 0.00206 . Ionization efficiency averaged $20 \mathrm{mV} / \mathrm{ng}$ of each $\mathrm{U}$ isotope. $\mathrm{U}$ mass fractionation was corrected using the known ${ }^{233} \mathrm{U} /{ }^{235} \mathrm{U}$ ratio of the Boise State University tracer solution.

$\mathrm{U}-\mathrm{Pb}$ dates and uncertainties were calculated using the algorithms of Schmitz and Schoene (2007), ${ }^{235} \mathrm{U} /{ }^{205} \mathrm{~Pb}$ of 77.93 and ${ }^{233} \mathrm{U} /{ }^{235} \mathrm{U}$ of 1.007066 for the Boise State University tracer solution, and $\mathrm{U}$ decay constants recommended by Jaffey et al. (1971). ${ }^{206} \mathrm{~Pb} /{ }^{238} \mathrm{U}$ ratios and dates were corrected for initial ${ }^{230}$ Th disequilibrium using a Th/U[magma] $=3.0 \pm 0.3$ using the algorithms of Crowley et al. (2007), resulting in an increase in the ${ }^{206} \mathrm{~Pb} /{ }^{238} \mathrm{U}$ dates of $\sim 0.09 \mathrm{Ma}$. All common $\mathrm{Pb}$ in analyses was attributed to laboratory blank and subtracted based on the measured laboratory $\mathrm{Pb}$ isotopic composition and associated uncertainty. $\cup$ blanks are estimated at $0.07 \mathrm{pg}$.

A weighted mean ${ }^{206} \mathrm{~Pb} /{ }^{238} \mathrm{U}$ date was calculated from equivalent dates using Isoplot 3.0 (Ludwig, 2003). The error of $\pm 0.013 \mathrm{Ma}$ on the weighted mean date is the internal error based on analytical uncertainties only, including counting statistics, subtraction of tracer solution, and blank and initial 
common $\mathrm{Pb}$ subtraction. Including the tracer calibration uncertainty propagated in quadrature increases the error to $\pm 0.016 \mathrm{Ma}$. Including the the ${ }^{238} \mathrm{U}$ decay constant uncertainty propagated in quadrature increases the error to $\pm 0.023 \mathrm{Ma}$. Internal error should be considered when comparing our date with ${ }^{206} \mathrm{~Pb} /{ }^{238} \mathrm{U}$ dates from other laboratories that used the same Boise State University tracer solution or a tracer solution that was cross-calibrated using EARTHTIME gravimetric standards. Error including the uncertainty in the tracer calibration should be considered when comparing our date with those derived from other geochronological methods using the U-Pb decay scheme (e.g., laser ablation ICPMS). Error including uncertainties in the tracer calibration and ${ }^{238} \mathrm{U}$ decay constant (Jaffey et al., 1971) should be considered when comparing our date with those derived from other decay schemes (e.g., ${ }^{40} \mathrm{Ar} /{ }^{39} \mathrm{Ar}$, $\left.{ }^{187} \mathrm{Re}-{ }^{187} \mathrm{OS}\right)$. Error for the weighted mean date and dates from individual grains are given at $2 \sigma$.

\section{References}

Crowley, J.L., Schoene, B., Bowring, S.A., 2007, U-Pb dating of zircon in the Bishop Tuff at the millennial scale: Geology 35:1123-1126.

Gerstenberger, H., Haase, G., 1997, A highly effective emitter substance for mass spectrometric $\mathrm{Pb}$ isotope ratio determinations: Chemical Geology 136:309-312.

Jaffey, A.H., Flynn, K.F., Glendenin, L.E., Bentley, W.C., and Essling, A.M., 1971, Precision measurements of half-lives and specific activities of ${ }^{235} \mathrm{U}$ and ${ }^{238} \mathrm{U}$, Physical Review $\mathrm{C}, 4: 1889-1906$.

Krogh, T.E., 1973, A low contamination method for hydrothermal decomposition of zircon and extraction of $\mathrm{U}$ and $\mathrm{Pb}$ for isotopic age determination: Geochimica et Cosmochimica Acta 37:485-494.

Ludwig, K.R., 2003, User's Manual for Isoplot 3.00. Berkeley Geochronology Center: Berkeley, CA, 70 p. Mattinson, J.M., 2005, Zircon U-Pb chemical abrasion ("CA-TIMS") method: combined annealing and multi-step partial dissolution analysis for improved precision and accuracy of zircon ages: Chemical Geology 220:47-66.

Schmitz, M.D., Schoene, B., 2007, Derivation of isotope ratios, errors and error correlations for U-Pb 
geochronology using ${ }^{205} \mathrm{~Pb}^{235} \mathrm{U}-\left({ }^{233} \mathrm{U}\right)$-spiked isotope dilution thermal ionization mass spectrometric data: Geochemistry, Geophysics, Geosystems $\left(G^{3}\right)$ 8, Q08006, doi:10.1029/2006GC001492.

\section{Appendix II}

\section{Geochronological Methods}

\section{Pacific Centre for Isotope and Geochemical Research - UBC}

${ }^{40} \mathrm{Ar} /{ }^{39} \mathrm{Ar}$ data presented in Table 2 and Appendix III were generated using the following methodology. Each sample was crushed and sieved to obtain fragments ranging in the size range from 0.5 to $1 \mathrm{~mm}$. A hand magnet was passed over the samples to remove magnetic minerals and metallic crusher fragments/spall. The samples were washed in deionized water, rinsed and then air-dried at room temperature.

Mineral separates were hand-picked, wrapped in aluminum foil and stacked in an irradiation capsule with similar-aged samples and neutron flux monitors (Fish Canyon Tuff sanidine; apparent age = $28.201 \pm 0.023 \mathrm{Ma} ; 1 \sigma$, Kuiper et al., 2008); MAC-83 biotite, 2 (Sandeman et al. 1999). The decay constant used was ${ }^{40} \mathrm{~K} \lambda_{\text {total }}=5.463 \pm 0.214 \times 10^{-10} / \mathrm{a}(2 \sigma)$ from Min et al. (2000).

The samples were irradiated at the McMaster Nuclear Reactor in Hamilton, Ontario, for 72 $\mathrm{MWH}$, with a neutron flux of approximately $3 \times 10^{16}$ neutrons $/ \mathrm{cm}^{2}$. Analyses $(n=33)$ of 11 neutron flux monitors irradiated with the samples produced errors of $<0.25 \%$ in the $J$ value $(2 \sigma)$.

The samples were analyzed at the Noble Gas Laboratory at the Pacific Centre for Isotopic and Geochemical Research, University of British Columbia. The separates were step-heated at incrementally higher powers in the defocused beam of a $10 \mathrm{~W} \mathrm{CO}$ laser (New Wave Research MIR10) until fused. The gas evolved from each step was analyzed by a VG5400 mass spectrometer equipped with an ioncounting electron multiplier. All measurements were corrected for total system blank, mass spectrometer sensitivity, mass discrimination, radioactive decay during and subsequent to irradiation, as well as interfering $\mathrm{Ar}$ from atmospheric contamination and the irradiation of $\mathrm{Ca}, \mathrm{Cl}$ and $\mathrm{K}$. The plateau and correlation ages were calculated using Isoplot ver.3.09 (Ludwig 2003). Errors are quoted at the 2sigma ( $95 \%$ confidence) level and are propagated from all sources except mass spectrometer sensitivity and age of the flux monitor. The term plateau age is defined as an age based on at least three 
consecutive steps that are within $2 \sigma$ error of each other, and together comprise at least $60 \%$ of the released ${ }^{39} \mathrm{Ar}$ for the aliquot.

\section{Geological Survey of Canada - Ottawa}

Selected samples were processed for ${ }^{40} \mathrm{Ar} /{ }^{39} \mathrm{Ar}$ analysis of muscovite by standard preparation techniques, including hand-picking of unaltered grains in the size range 0.25 to $0.50 \mathrm{~mm}$. Individual mineral separates were loaded into aluminum foil packets along with grains of Fish Canyon Tuff Sanidine (FCT-SAN) to act as flux monitor (apparent age = 28.201 $\pm 0.023 \mathrm{Ma}$; 16, Kuiper et al., 2008). The sample packets were arranged radially inside an aluminum can. The samples were submitted for a $60 \mathrm{MWH}$ irradiation in high flux position $5 \mathrm{c}$ at the research reactor of McMaster University in Hamilton, Ontario, Canada.

Laser ${ }^{40} \mathrm{Ar} /{ }^{39} \mathrm{Ar}$ step-heating analysis was carried out at the Geological Survey of Canada geochronology laboratories in Ottawa, Ontario. Upon return from the reactor, the sample was loaded into a $1.5 \mathrm{~mm}$-diameter hole in a copper planchet. The planchet was then placed in the extraction line and the system evacuated. Heating of individual sample aliquots in steps of increasing temperature was achieved using a Merchantek MIR10 10W CO $\mathrm{CO}_{2}$ laser equipped with a $2 \mathrm{~mm} \times 2 \mathrm{~mm}$ flat-field lens. The released Ar gas was cleaned in the extractions line over two hot SAES ${ }^{\mathrm{TM}}$ NP-10 getters of St 707 alloy (Zr$\mathrm{V}$-Fe) held at $\sim 400^{\circ} \mathrm{C}$ (to remove nitrogen, oxygen, hydrocarbons, water and other active gases) and a room-temperature getter containing HY-STOR ${ }^{\circledR} 201$ calcium-nickel alloy pellets (to remove hydrogen), and then analyzed isotopically using a Nu Instruments Noblesse noble gas mass spectrometer, equipped with a Faraday detector and three ion counters. For the analyses, a single ion counter peak-hopping mode was used for small signals, ('SC' mode as described in Kellett and Joyce, 2014) and in cases where the ${ }^{40} \mathrm{Ar}$ signal exceeded ion counting tolerance, a Faraday plus single ion counter peak-hopping routine was employed $\left({ }^{38} \mathrm{Ar}\right.$ was not measured for these runs) Baselines were measured prior to each analysis. Blank measurements were made throughout the analytical sessions, the values for which are included in Appendix II. Mass fractionation and detector efficiencies were determined from repeated measurements of air aliquots, whereby ${ }^{40} \mathrm{Ar}$ and ${ }^{36} \mathrm{Ar}$ signals were measured on all collectors. The efficiency of the ICO ion counter used in the measurements was determined to be $0.9359 \pm 0.006 \%(1 \sigma)$ relative to the Faraday collector. Deadtime of the ICO collector was $20 \mathrm{~ns} .{ }^{40} \mathrm{Ar} /{ }^{36} \mathrm{Ar}$ ratios were then determined for each collector individually, and for each combination of collectors (ex. ${ }^{40} \mathrm{Ar}$ on the Faraday $/{ }^{36} \mathrm{Ar}$ on each ion counter). Raw data from the mass spectrometer was imported and processed 
using in-house Excel ${ }^{\circledast}$ data handling macros that employ average, linear or non-linear regression protocols based on the equations of Koppers (2002).

Error analysis on individual steps follows numerical error analysis routines outlined in Scaillet (2000) and error analysis on grouped data follows algebraic methods of Roddick (1988). Corrected argon isotopic data are listed in Appendix II, and presented (Figure 9g) as a spectrum of gas release and inverse-isochron plot (Roddick et al. 1980). .

Neutron flux gradients throughout the sample canister were evaluated by analyzing the sanidine flux monitors included with each sample packet and interpolating a linear fit against calculated J-factor and sample position. The error on individual J-factor values is conservatively estimated at $\pm 0.6 \%(2 \sigma)$. Because the error associated with the J-factor is systematic and not related to individual analyses, correction for this uncertainty is not applied until calculation of dates from isotopic correlation diagrams (Roddick 1988). The decay constant used was ${ }^{40} \mathrm{~K} \lambda_{\text {total }}=5.463 \pm 0.214 \times 10^{-10} / \mathrm{a}(2 \sigma)$ from Min et al. (2000). Nucleogenic interference corrections were $\left({ }^{40} \mathrm{Ar} /{ }^{39} \mathrm{Ar}\right)_{\mathrm{K}}=0.025 \pm .005,\left({ }^{38} \mathrm{Ar} /{ }^{39} \mathrm{Ar}\right)_{\mathrm{K}}=0.011 \pm 0.010$, $\left({ }^{40} \mathrm{Ar} /{ }^{37} \mathrm{Ar}\right)_{\mathrm{Ca}}=0.002 \pm 0.002,\left({ }^{39} \mathrm{Ar} /{ }^{37} \mathrm{Ar}\right)_{\mathrm{Ca}}=0.00068 \pm 0.00004,\left({ }^{38} \mathrm{Ar} /{ }^{37} \mathrm{Ar}\right)_{\mathrm{Ca}}=0.00003 \pm 0.00003$, $\left({ }^{36} \mathrm{Ar} /{ }^{37} \mathrm{Ar}\right)_{\mathrm{Ca}}=0.00028 \pm 0.00016$. MSWD is defined as the mean square of weighted deviates. All errors are quoted at the $2 \sigma$ level of uncertainty.

\section{References}

Kellett, D. and Joyce, N. 2014. Analytical details of the single- and multicollection ${ }^{40} \mathrm{Ar} /{ }^{39} \mathrm{Ar}$ measurements for conventional step-heating and total-fusion age calculation using the $\mathrm{Nu}$ Noblesse at the Geological Survey of Canada. Geological Survey of Canada, Technical Note 8, 27 p.

Koppers, A.A.P. 2002. ArArCALC - software for 40Ar/39Ar age calculations. Comp. \& Geosc. 28: 14.

Kuiper, K. F., A. Deino, F. J. Hilgen, W. Krijgsman, P. R. Renne and J. R. Wijbrans, 2008. Synchronizing rock clocks of Earth history. Science, 320, 500-504.

Ludwig, K.R. 2003. Isoplot 3.0, A geochronological toolkit for Microsoft Excel. University of California at Berkley.

Min, K., Mundil, R., Renne, P.R., Ludwig, K.R., 2000. A test for systematic errors in ${ }^{40} \mathrm{Ar} /{ }^{39} \mathrm{Ar}$ geochronology through comparison with $\mathrm{U} / \mathrm{Pb}$ analysis of a $1.1 \mathrm{Ga}$ rhyolite. Geochimica Cosmochimica Acta, 64, 73-98.

Roddick, J.C. 1988. The assessment of errors in ${ }^{40} \mathrm{Ar} /{ }^{39} \mathrm{Ar}$ dating. In Radiogenic Age and Isotopic Studies, Report 2. Geological Survey of Canada. pp. 7-16.

Roddick, J.C., Cliff, R.A., and Rex, D.C. 1980. The evolution of excess argon in alpine biotites - A40Ar- 
39Ar analysis. Earth Planet. Sci. Letter 48(1): 185-208. doi: http://dx.doi.org/10.1016/0012821X(80)90181-8

Sandeman, H.A., Archibald, D.A., Grant, J.W., Villeneuve, M.E., and Ford, F.D. 1999. Characterization of the chemical composition and 40Ar/39Ar systematics of intralaboratory standard MAC-83biotite. In Radiogenic age and isotopic studies: Report 12; Geological Survey of Canada, Current Research, 1999-F. pp. 13-26.

Scaillet, S. 2000. Numerical error analysis in 40Ar/39Ar dating. Chemical Geology, 162(3-4): 269-298. doi: http://dx.doi.org/10.1016/S0009-2541(99)00149-7. 


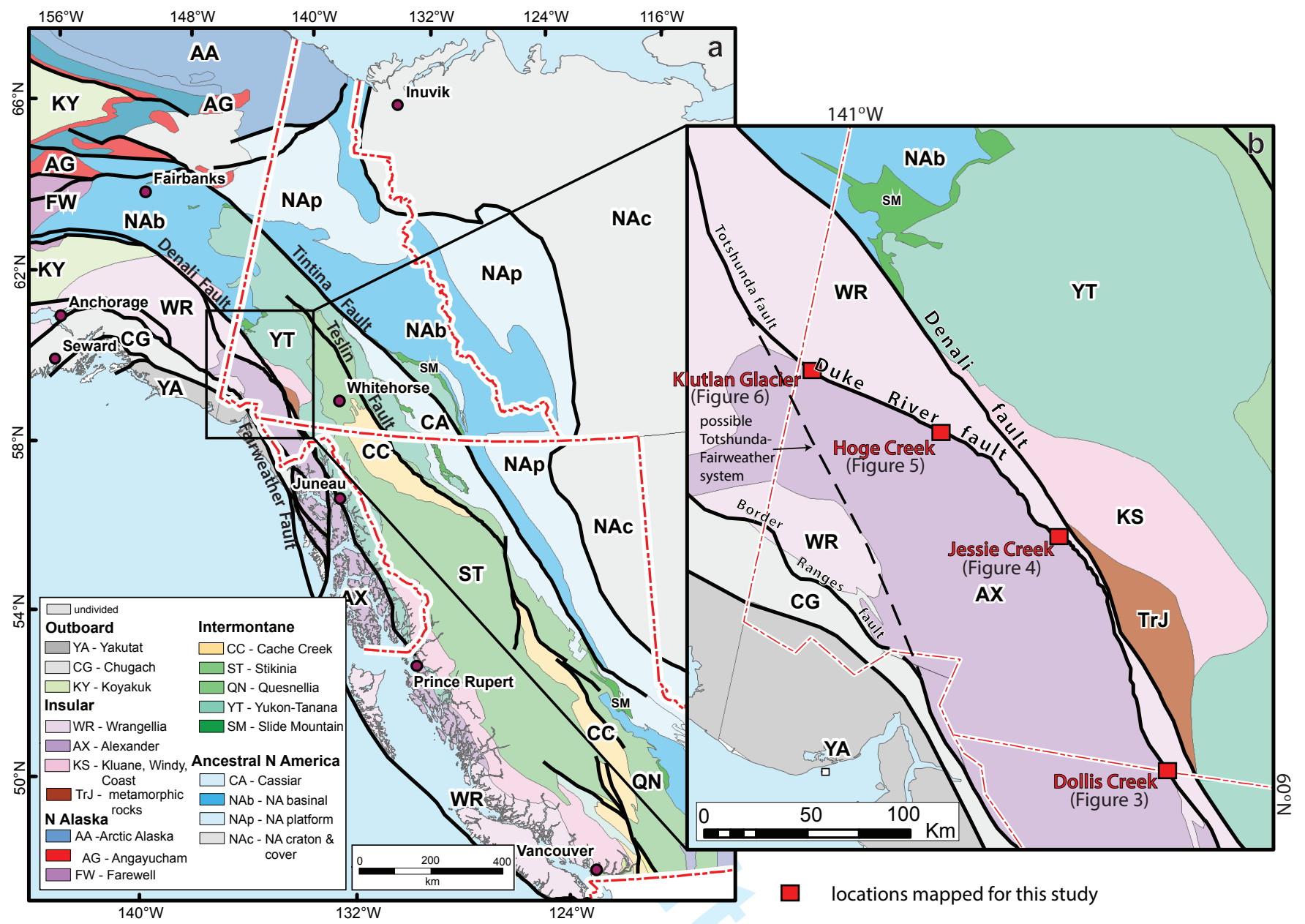

Figure 1 


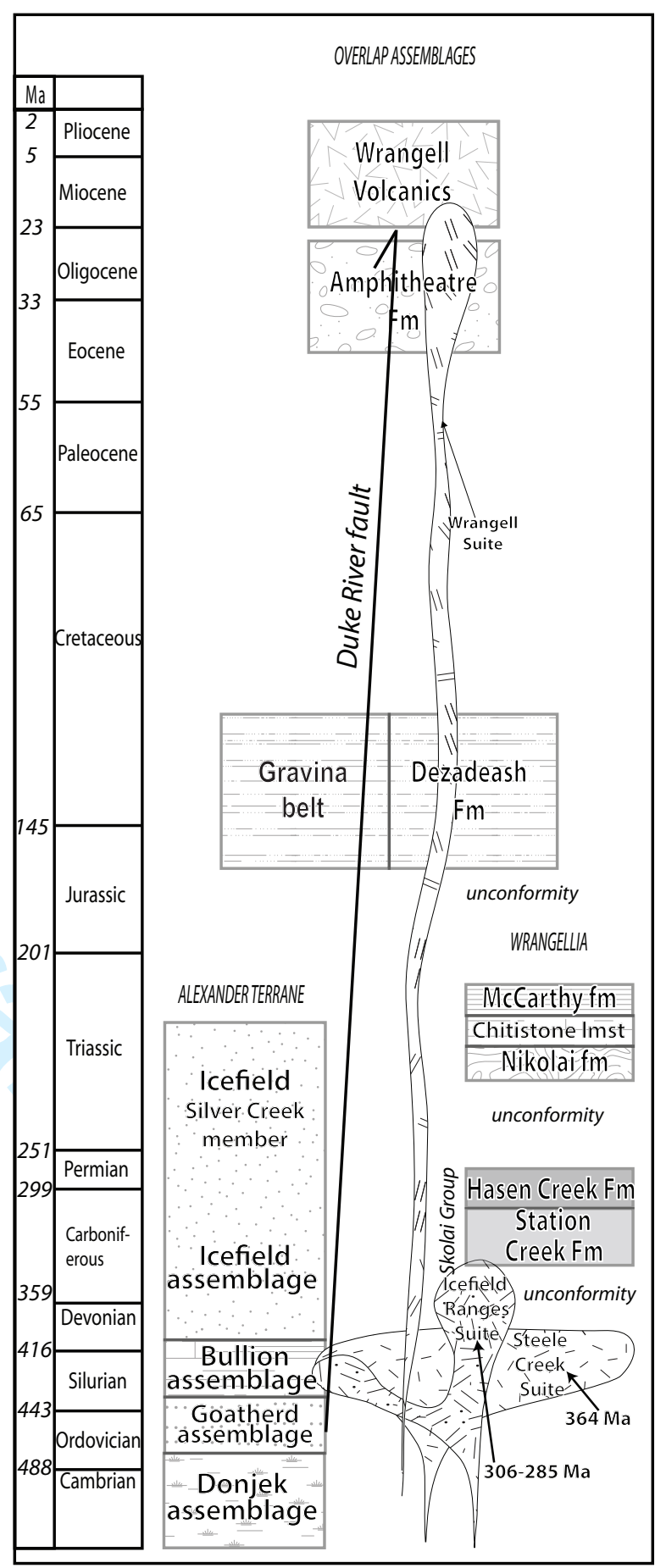

Figure 2 


\section{INTRUSIVE ROCKS}

\section{MIOCENE}

Wrangell Suite

fine to medium-grained, hornblende-biotite-pyroxene diorite; fine to medium-grained hornblende-biotite granodiorite to quartz monzonite occurring as dykes

\section{EARLY CRETACEOUS}

\section{Pyroxenite Creek Suite}

EKP biotite-hornblende diorite; green medium-grained,

foliated, pyroxene-epidote gabbro

EKS2 dark green to black pyroxene gabbro and pyroxenite

\section{DEVONIAN}

Steele Creek Suite

DSC green to purple medium- to coarse-grained hornblendepyroxene gabbro that is locally highly altered

\section{LAYERED ROCKS}

MIOCENE

Wrangell volcanics

NW dark grey to black, fine-grained amygdaloidal basalt

NW2 biege, fine-grained crystal-lithic tuff

\section{WRANGELLIA}

\section{TRIASSIC}

\section{Chitistone limestone}

UTC grey massive limestone

\section{Skolai Group}

\section{PERMIAN-PENNSYLVANIAN}

\section{Hasen Creek Formation}

light grey to brown, calcareous, fossiliferous packstone; medium-grained litharenite sandstone grades into a poorly

$\mathrm{PHC}$ bedded pebble conglomerate with coarse-grained sandstone interbeds; light to medium grey, massive to bedded limestone; dark grey, thin-bedded siltstone

PHc2 light grey, laminated to massive limestone

PHc3 green and maroon boulder conglomerate dominated by wellrounded clasts of gabbro and diorite; locally maroon volcanic breccia with a sandy matrix

\section{MISSISSIPPIAN TO PENNSYLVANIAN}

\section{Station Creek Formation}

MPSv laminated to thinly bedded, light grey to light green volcanic tuff and volcaniclastic siltstone; local crystal-rich tuff interbedded with fine-grained volcanic ash

interbedded volcanic breccia, agglomerate and volcaniclastic sandstone dominated by pyroxene-phyric volcanic breccia; rare light grey-weathered, dark green to black, pyroxenephyric basalt flows

\section{ALEXANDER TERRANE}

\section{DEVONIAN TO TRIASSIC}

Icefield assemblage: Silver Creek member

DTI18 dark grey to black, fine-grained, calcareous siltstone; brown to grey, thin-bedded chert; rare crinoidal limestone

green and maroon, foliated conglomerate that grades upwards into maroon, medium-grained sandstone

\section{Icefield assemblage}

DKI6 light grey to white, massive marble

DK/4b undifferentiated calcareous and carbonaceous siltstone; fine to medium-grained chlorite schist; grey banded limestone to marble

DTI4 massive to thin-bedded limestone and marble; calcareous siltstone

dark grey, fine-grained, locally amygdaloidal, plagioclase-phyric basalt; green, volcanic breccia made up of basalt clasts; rare biege crystal tuff

dark grey, thin-bedded, calcareous and carbonaceous siltstone

DTI2 and phyllite; carbonaceous, calcareous, feldspar-muscovite-quartz schist to phyllite; rare muscovite-rich quartzite

light green, fine-grained feldspar-quartz (?) schist and phyllite;

DTI1 very fine grained phyllonite; fine-grained, calcareous, muscovitefeldspar +/- quartz schist and phyllite; fine-grained, carbonaceous muscovite-felspar schist and cabonaceous quartz-muscovite schist

\section{SILURIAN TO DEVONIAN}

\section{Bullion assemblage}

light grey, massive to well-bedded limestone or marble, dark grey, thin-bedded limestone or marble; minor dark blue-grey calcareous argillite or phyllite

\section{ORDOVICIAN}

Donjek formation

COD grey, laminated marble

COD1 dark green, fine to medium-grained basalt; basalt breccia

geologic contacts

(defined, approximate, inferred).

fault (movement not known).

thrust fault (defined, approximate).

mapping limit..

fold axial surface trace (upright - anticline, syncline; overturned anticline, syncline)....... lineation (elongation).

crenulation lineation

fold axis (dominant phase).

bedding ......

foliation (dominant)

vein

fault plane

isotopic and fossil age sample locations (U-Pb, Ar/Ar, fossil)

cross section line

field station

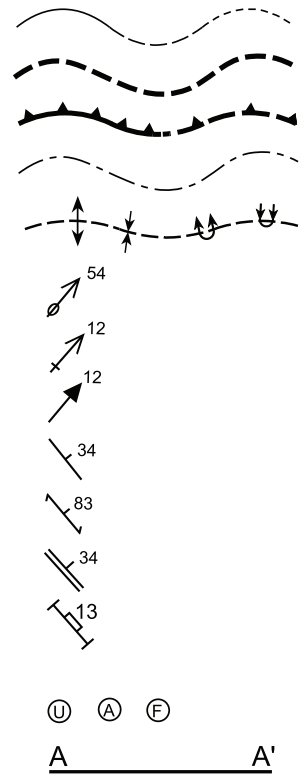

Figure 3 


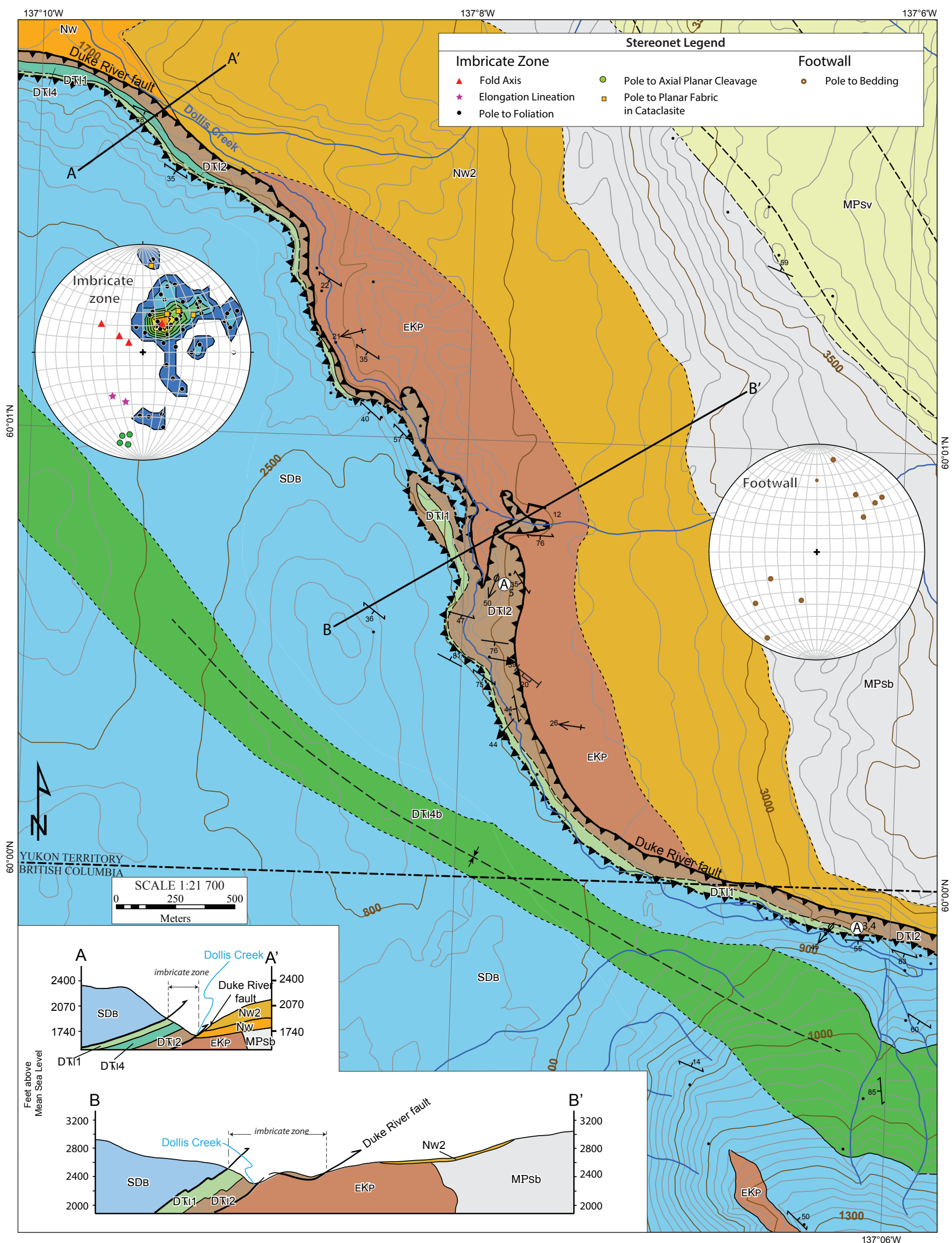

Figure 3 


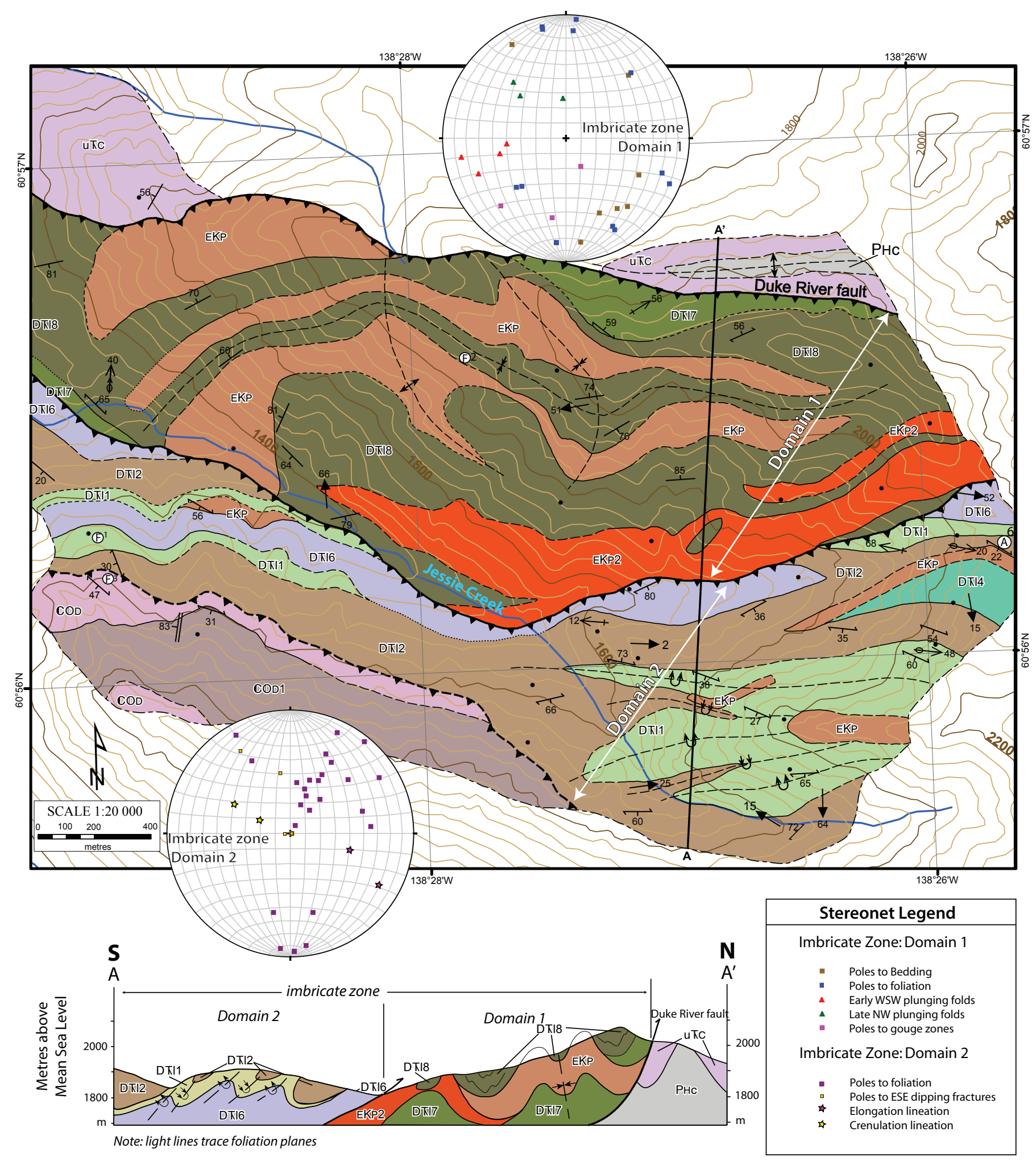

Figure 4 
Figure 5

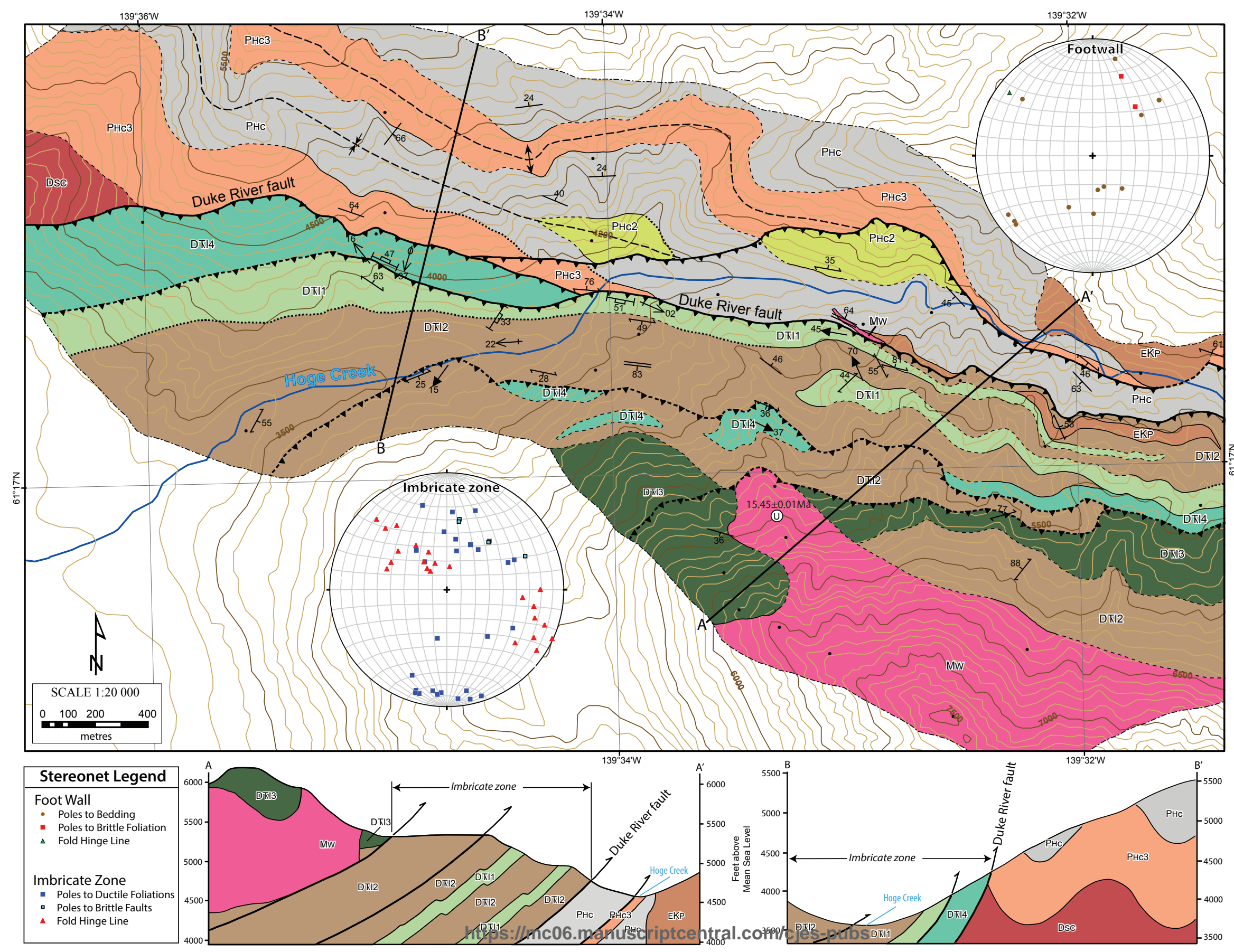




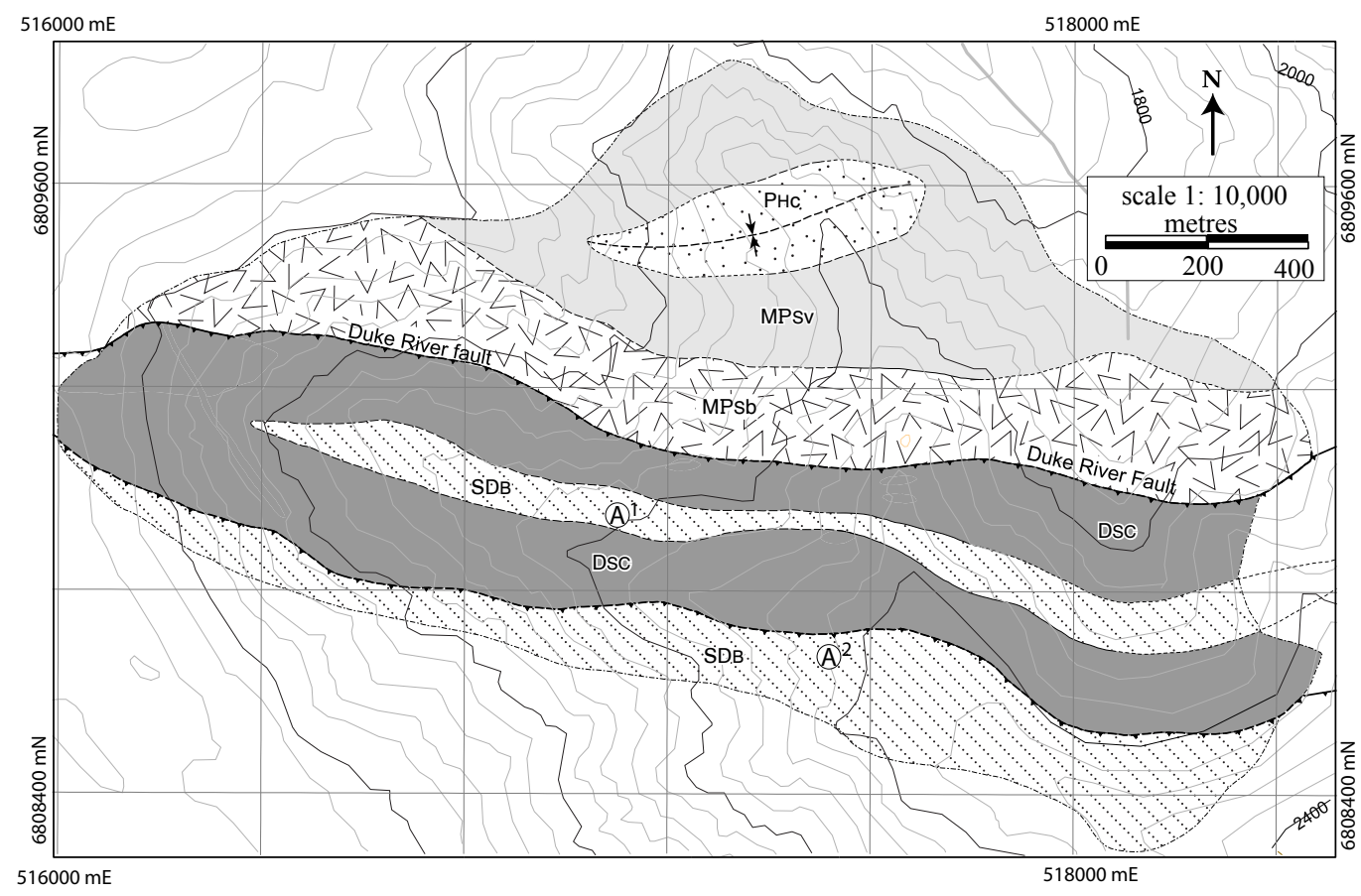

Hasen Creek Formation

P.HC' grey-brown, fine-grained sandstone interbedded with medium- to coarse-grained sandstone; locally contains beds of conglomerate

Station Creek Formation

laminated to thinly bedded, dark-grey to green volcanic tuff and volcaniclastic siltstone

MPSb dark green, fine-grained basalt; rare pillow basalt

\section{Steele Creek Suite}

DSC massive, locally foliated, grey-green hornblende-pyroxene gabbro; minor medium-grained gabbro diabase; locally leucocratic gabbro

\section{Bullion assemblage}

SDB fine-grained, carbonaceous mica schist; fine- to medium-grained greenschist: thin-bedded marble; muscovite-bearing quartzite

Figure 6. 

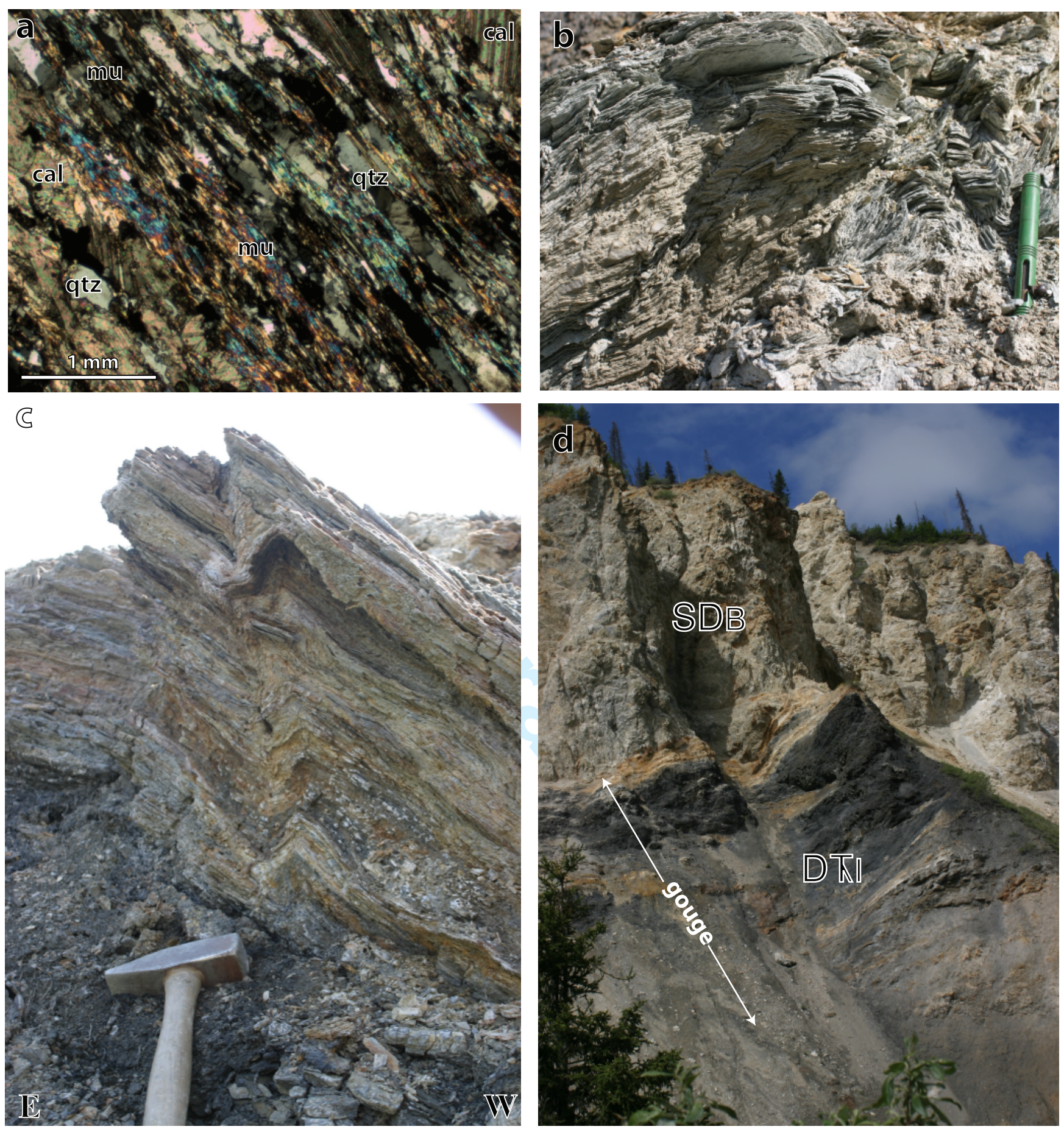

Figure 7 

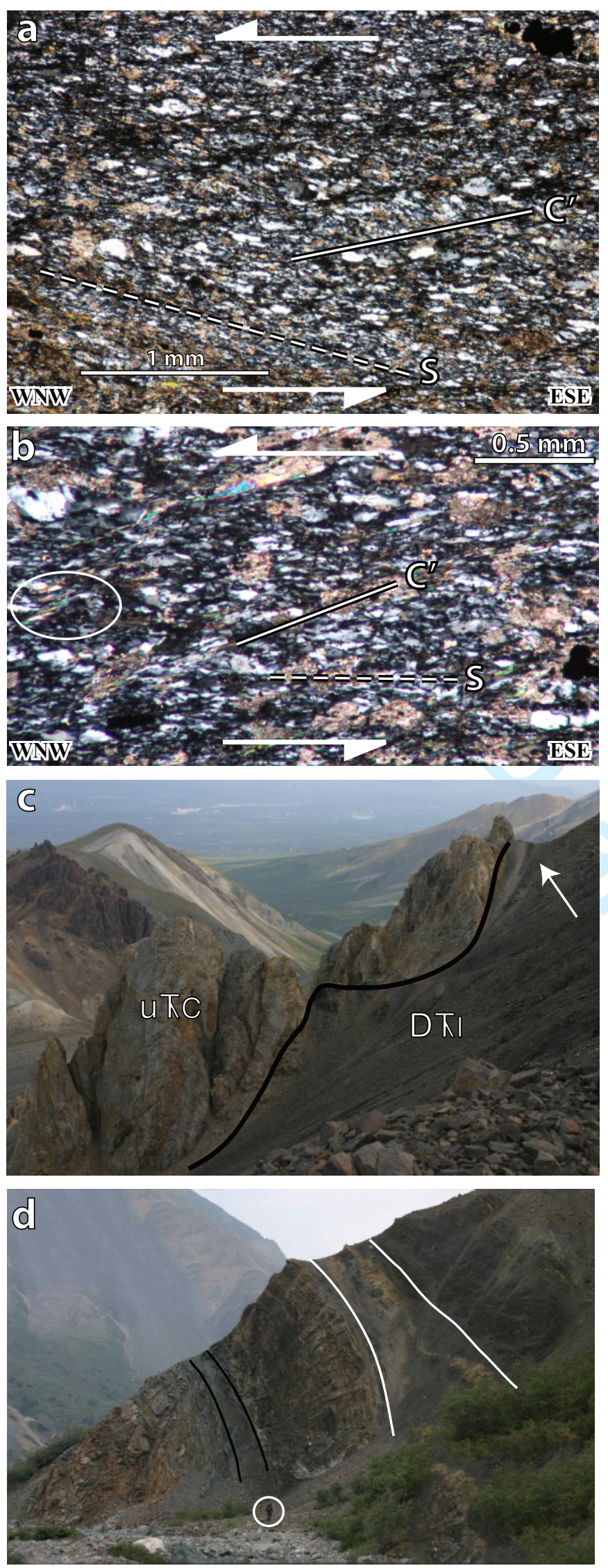

Figure 8 

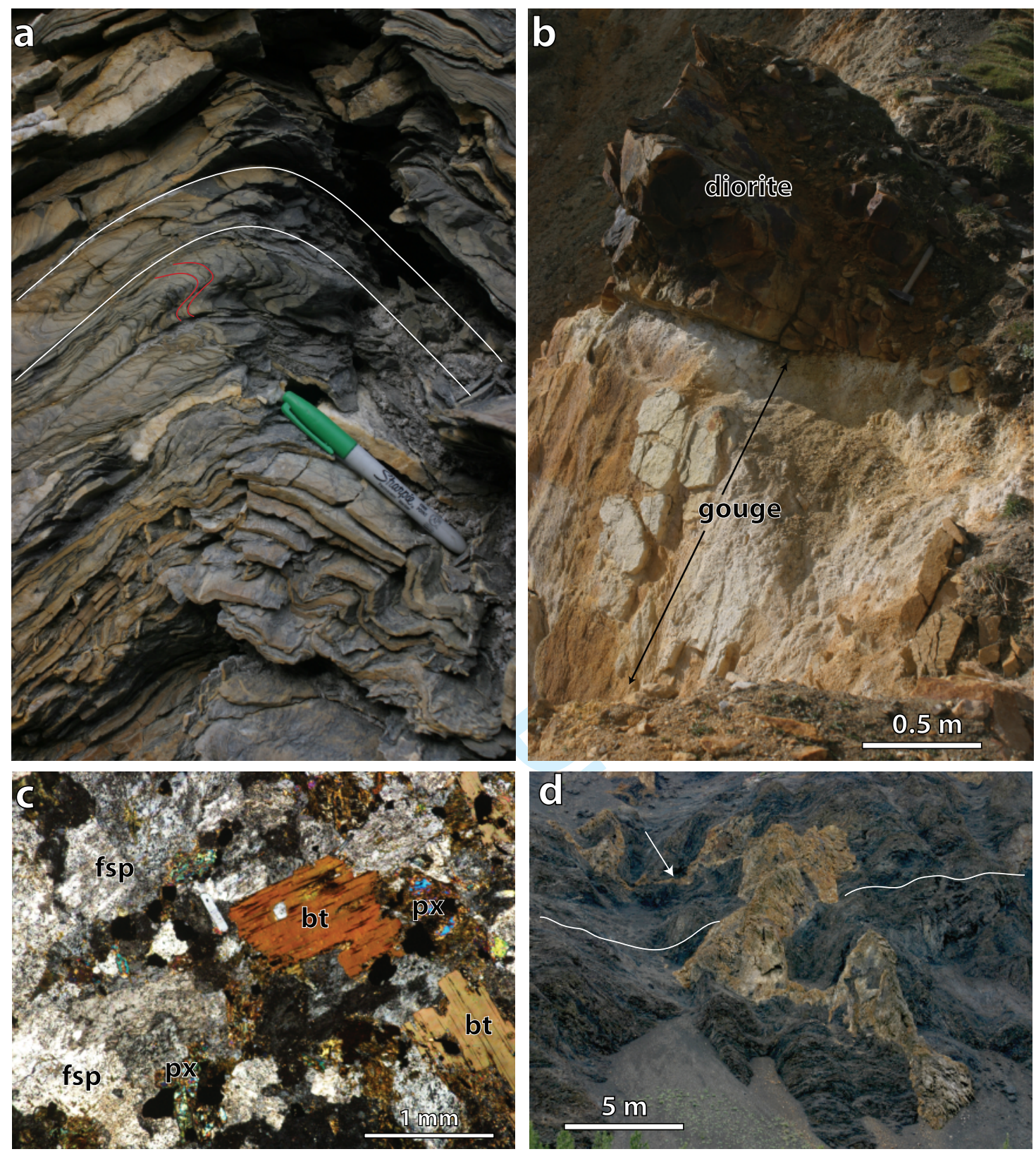

Figure 9 

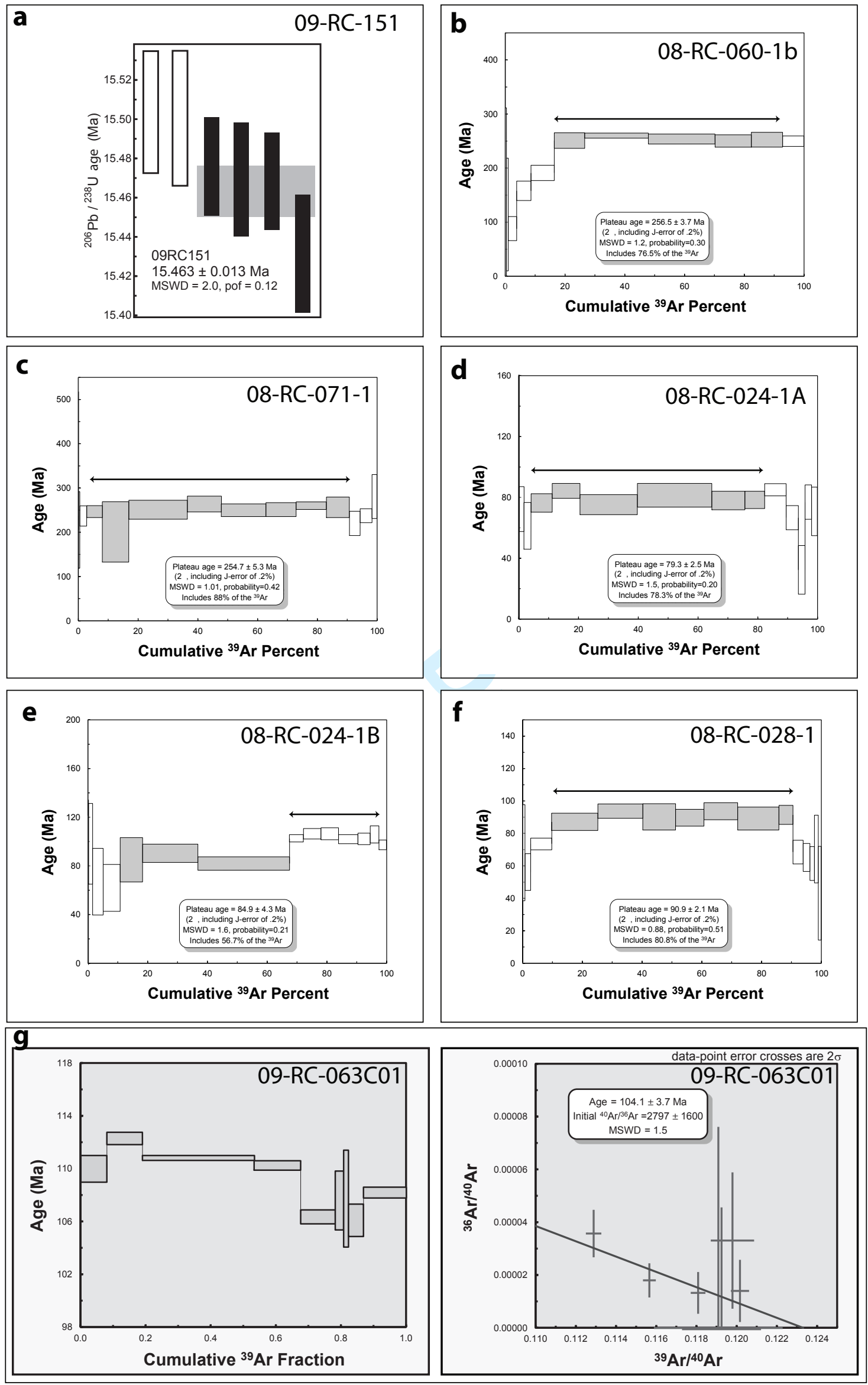

Figure 10 


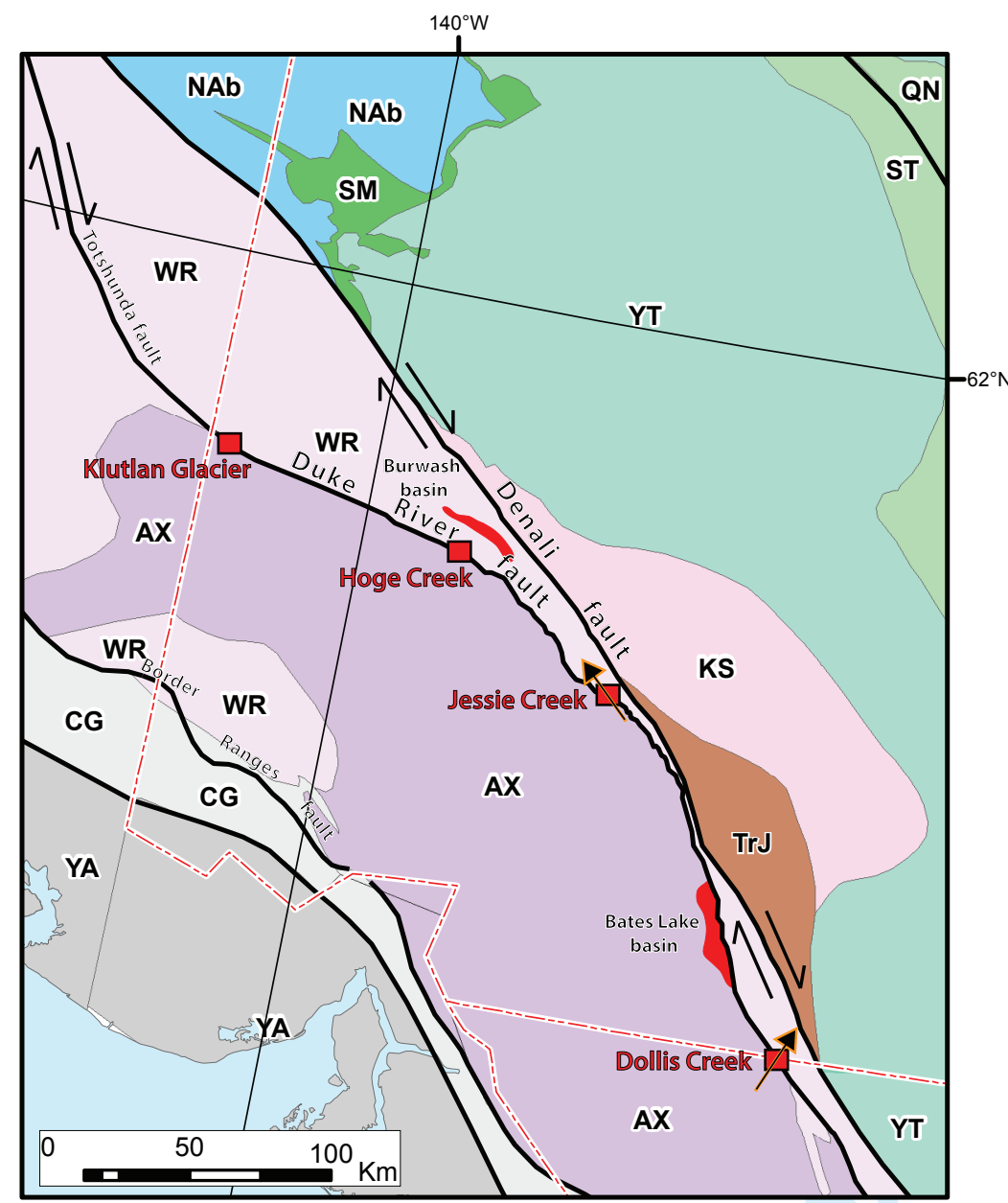

Strike-slip basins

Transport direction of Duke River fault based on orientation of

elongation lineations within the imbricate zone

Figure 11 


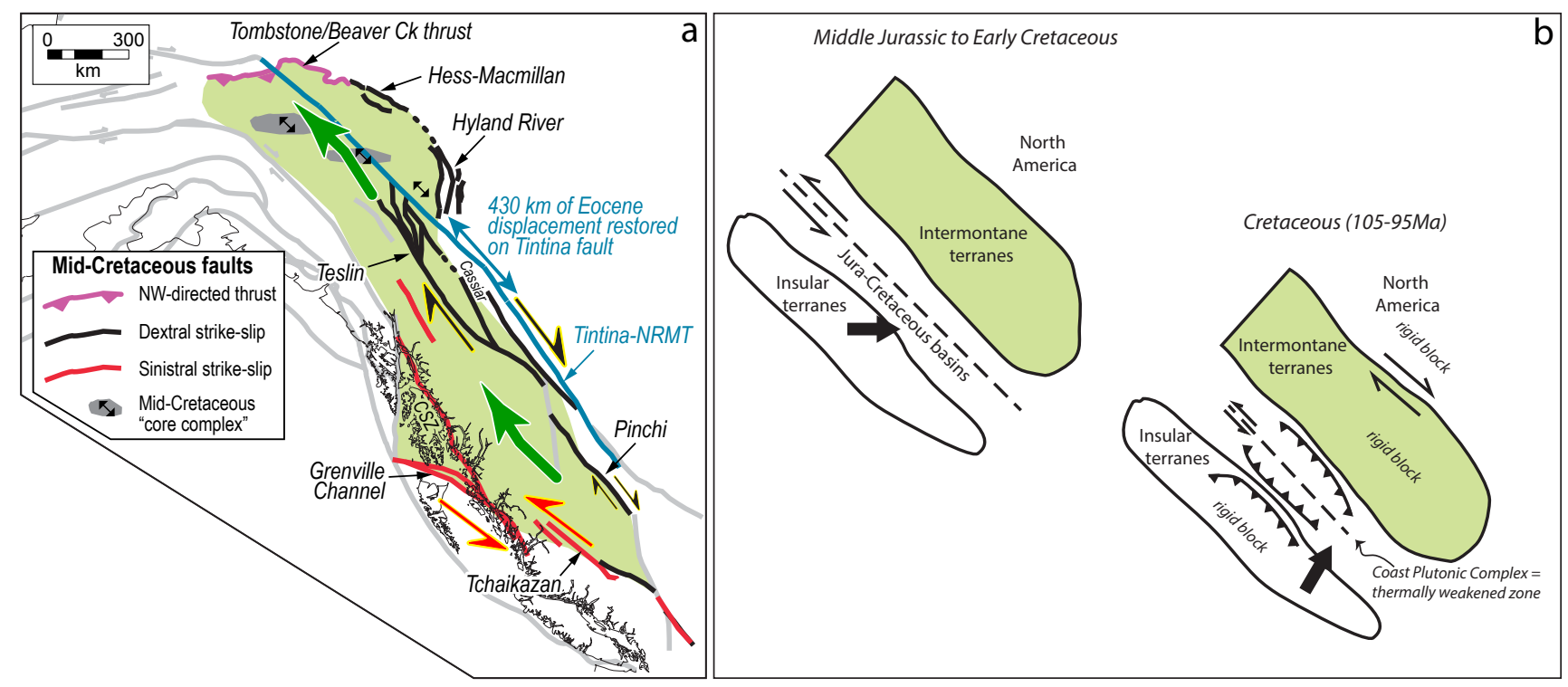

Figure 12 